\title{
TAF10 fehérjék szerepe Drosophila melanogaster-ben
}

Doktori értekezés

Készítette: Páhi Zoltán Gábor

Témavezetők:

Prof. Dr. Boros Imre Miklós

Dr. Pankotai Tibor

\author{
Szegedi Tudományegyetem \\ Természettudományi és Informatikai Kar \\ Biokémiai és Molekuláris Biológiai Tanszék
}

Szeged 


\section{Tartalom:}

RÖVIDÍTÉSEK....................................................................................................................4

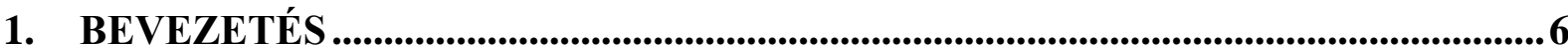



1.2. Hisztonok poszttranszlációs módosításainak hatása a kromatin szerkezetre ................. 7

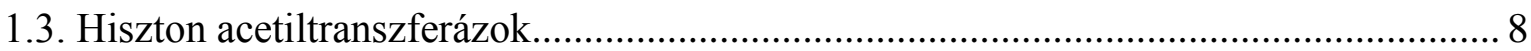

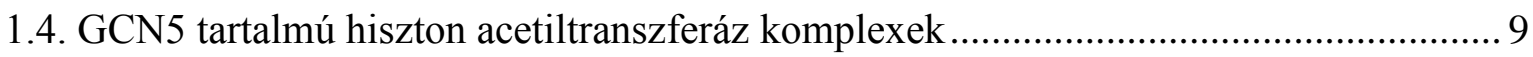



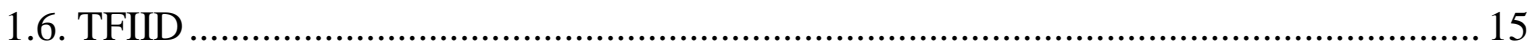

1.7. A TAF fehérjék elnevezése és ortológjai különböző organizmusokban ...................... 17

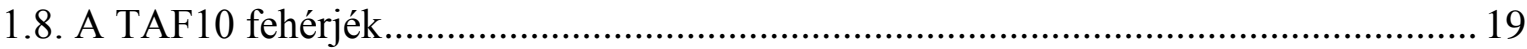

1.9. Az ekdizon szabályozása és bioszintézise Drosophila melanogaster-ben .................... 21

2. CÉLKITÜZÉSEK

2.1. Vizsgálni, hogy a dTAF10/dTAF10b fehérjék hogyan befolyásolják a Drosophila melanogaster egyedfejlődését

2.2. Vizsgálni, hogy a dTAF10/dTAF10b fehérjék hogyan befolyásolják a dSAGA hiszton acetiltranszferáz komplex müködését.

2.3. Vizsgálni, hogy a dTAF10/dTAF10b fehérjék hogyan befolyásolják a dTFIID komplex összeszerelődését

3. ANYAGOK ÉS MÓDSZEREK

3.1. Drosophila melanogaster törzsek és keresztezések ................................................... 24

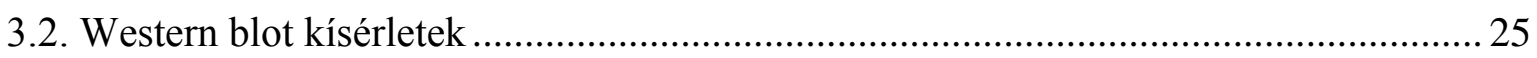

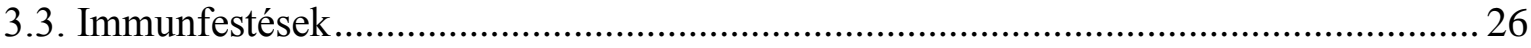

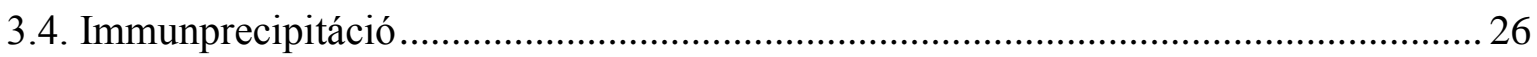



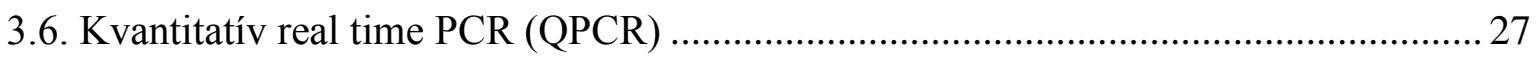

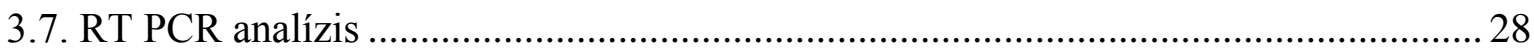

3.8. $d A d a 2 b^{d 842}, d A d a 2 a^{d 189}, d T a f 10^{d 25}$ és $w^{1118}$ Drosophila melanogaster törzsek

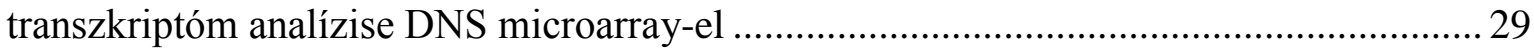



4. EREDMÉNYEK

4.1. dTaf10/dTaf10b deléciók létrehozása 30

4.2. Génexpresszió változások összehasonlítása a dTAF10/dTAF10b fehérjéket nem

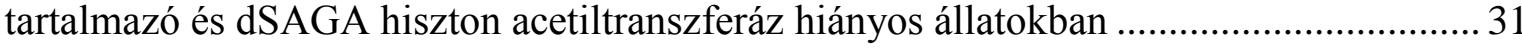

4.3. dTAF10/dTAF10b hiányának hatása a dSAGA specifikus acetilációra 
4.4. dTAF10 és dTAF10b fehérjéket nem tartalmazó Drosophilák génexpressziós változásainak összehasonlítása a $d A d a 2 a^{d 189}$ (dATAC) mutánsokban tapasztalt transzkripciós változásokkal

4.5. dTAF10 és dTAF10b hiányának hatása a dATAC, illetve GCN5 specifikus acetilációra

4.6. A dTAF10 és a dTAF10b szerepe a dTFIID alegységek összeszerelődésében ........... 37

4.7. A dTAF10 és dTAF10b hiányában kialakuló fenotípusok vizsgálata......................... 41

4.8. A dTaf5, dTaf8 és $d T a f 10$ gének expressziójának csökkentése gyürümirigyben......... 43

4.9. Az ekdizon bioszintézisben résztvevő Halloween gének vizsgálata $d T a f 10^{d 25}$ mutánsokban

5. EREDMÉNYEK MEGVITATÁSA

5.1. A dTAF10 fehérjék szerepe a Drosophila fejlödésében ........................................... 47

5.2. dTAF10 és dTAF10b hatása a dTFIID multiprotein komplexre.................................. 48

5.3. A dTAF10 fehérje tartalmú komplexek valamint a dATAC kapcsolata .......................50 50

5.4. A dTAF10 fehérje tartalmú komplexek és a dSAGA kapcsolata.................................. 51

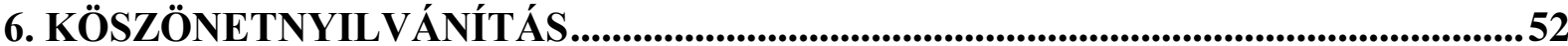

7. IRODALOMJEGYZÉK ...........................................................................................53

8. TARTALMI ÖSSZEFOGLALÓ ................................................................................................60

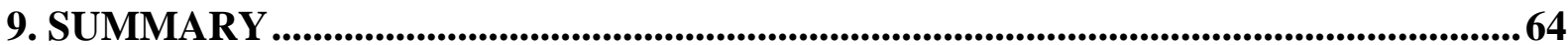




\section{Rövidítések}

ADA2: alteration/deficiency in activation-2

ADA3: alteration/deficiency in activation-3

ATAC: ADA two a containing complex

ATAC1: ATAC component 1

ATAC2: ATAC component 2

CBP: CREB-binding protein

CDK: cyclin-dependent kinase

CHRAC17: Chromatin accessibility complex $17 \mathrm{kDa}$ protein

DSIF: DRB sensitivity-inducing factor

Gcn5: general control nonderepressible 5

GNAT: Gcn5-related N-acetyltransferase

HAT: Histone acetyltransferase

HCF1: Host cell factor 1

MBIP: MAP3K12-binding inhibitory protein 1

MYST: Morf, Ybf2, Sas2, Tip 60 containing protein family

NC2ß: Negative cofactor 2-beta

NELF: negatív elongációs faktor

p300/CBP: protein of $300 \mathrm{kDa}$ and CREB-binding protein

PCAF: p300/CBP-associated factor

P-TEFb: positive transcriptional elongation factor $b$

SAGA: Spt-Ada-Gcn5 containing acetyltransferase complex

SANT: olyan domén, mely a Swi3-Ada2-NCoR-TFIIIB fehérjékben található

SGF: SAGA-associated factor 
SPT: Suppressor of Ty element

SRC: szteroid receptor koaktivátor 1

SUS1: S1 gene upstream of ySa1

TAF: TATA box-binding protein-associated factor

TBP: TATA Binding Protein

TFIID: Transcription Factor II D

UBP8: ubiquitin-specific processing protease 8

XPB: Xeroderma pigmentosum B

XPD: Xeroderma pigmentosum D

WDA: will decrease acetylation

WDR: WD repeat-containing protein

WDS: will die slowly

YEATS2: YEATS domain-containing protein 2

ZNF: Zinc finger 


\section{Bevezetés}

\subsection{A nukleoszóma és a kromatin szerveződése}

A DNS tömörítés nélkül nem férne el az eukarióta sejtek mikroszkopikus méretü sejtmagjában, ezért szükség van egy kompakt szerkezet létrehozására, melyben hiszton fehérjék vesznek részt. A DNS a pozitív töltésű hiszton fehérjékhez kapcsolódik, ezáltal létrejön a kromatin alapegysége, a nukleoszóma. A H2A, H2B, H3 és a H4 hiszton fehérjék oktamert alkotva, két kópiában vannak jelen a nukleoszómákban [1]. A hiszton fehérjék szerkezetére jellemző az úgynevezett „hiszton-fold domén” (HF), mely 3 alfa helikális részből $(\alpha 1, \alpha 2, \alpha 3)$ és az ezeket összekötő nem helikális szerkezetű loop régiókból áll (1. ábra) [1]. A hiszton-fold domének a fehérje-fehérje kölcsönhatások kialakításában és a DNS kötésében vesznek részt [1].

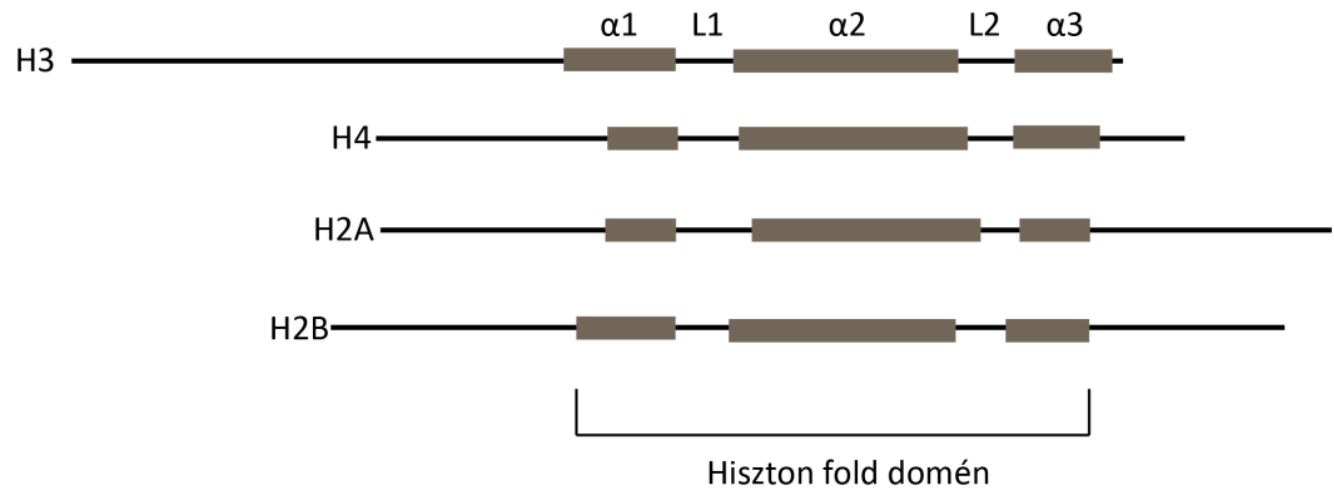

1. ábra: Core-hiszton fehérjék szerkezete sematikusan ábrázolva. A téglalapok a fehérjefehérje kölcsönhatás kialakításában részt vevő helikális szerkezetü hiszton-fold doméneket $(\alpha 1, \alpha 2$, a3) jelölik. Az L1 és az L2-vel jelölt részek a hélixeket összekötő nem helikális szerkezetü loop régiókra vonatkoznak. Luger K 1997 alapján módosítva [1].

A nukleoszómában előforduló hiszton fehérjék közül a H3 a H4-gyel, a H2A pedig a H2B-vel alkot dimert. Először kettő H3-H4 dimer rendeződik egy tetramer szerkezetbe, melyhez egy 60 bázispárnyi DNS szakasz kötődik, majd ehhez a struktúrához kapcsolódik a két H2A-H2B dimerből álló tetramer. Az így kialakuló nukleoszóma mag köré körülbelül 1,7 csavarulatot képezve tekeredik 146 bázispár DNS [2]. A nukleoszómák között lévő, körülbelül 50-60 bázispár hosszúságú DNS szakaszhoz kötődik a H1 fehérje. A nukleoszómák feltekeredésével alakul ki a szolenoid struktúra, amely egy tömör $30 \mathrm{~nm}$-es kromatin szálat jelent. A szolenoid szerkezetnél 6 nukleoszóma alkot egy csavarulatot. A szolenoidok további hurkolódásával egy kompaktabb, $300 \mathrm{~nm}$ átméröjü kromatinszál keletkezik, végül létrejön egy 700 nm-es szál, ami a kromoszóma kromatidáit alkotja [3] (2. ábra). A transzkripció és a replikáció során a polimerázoknak hozzá kell férniük a DNS 
szálaihoz, azonban a tömör kromatin szerkezet akadályozza ezt, ezért szükség van a kromatin szerkezet dinamikus változására. A nyitott kromatin szerkezet teszi lehetővé, hogy a DNS szakaszain a transzkripció végbemenjen.

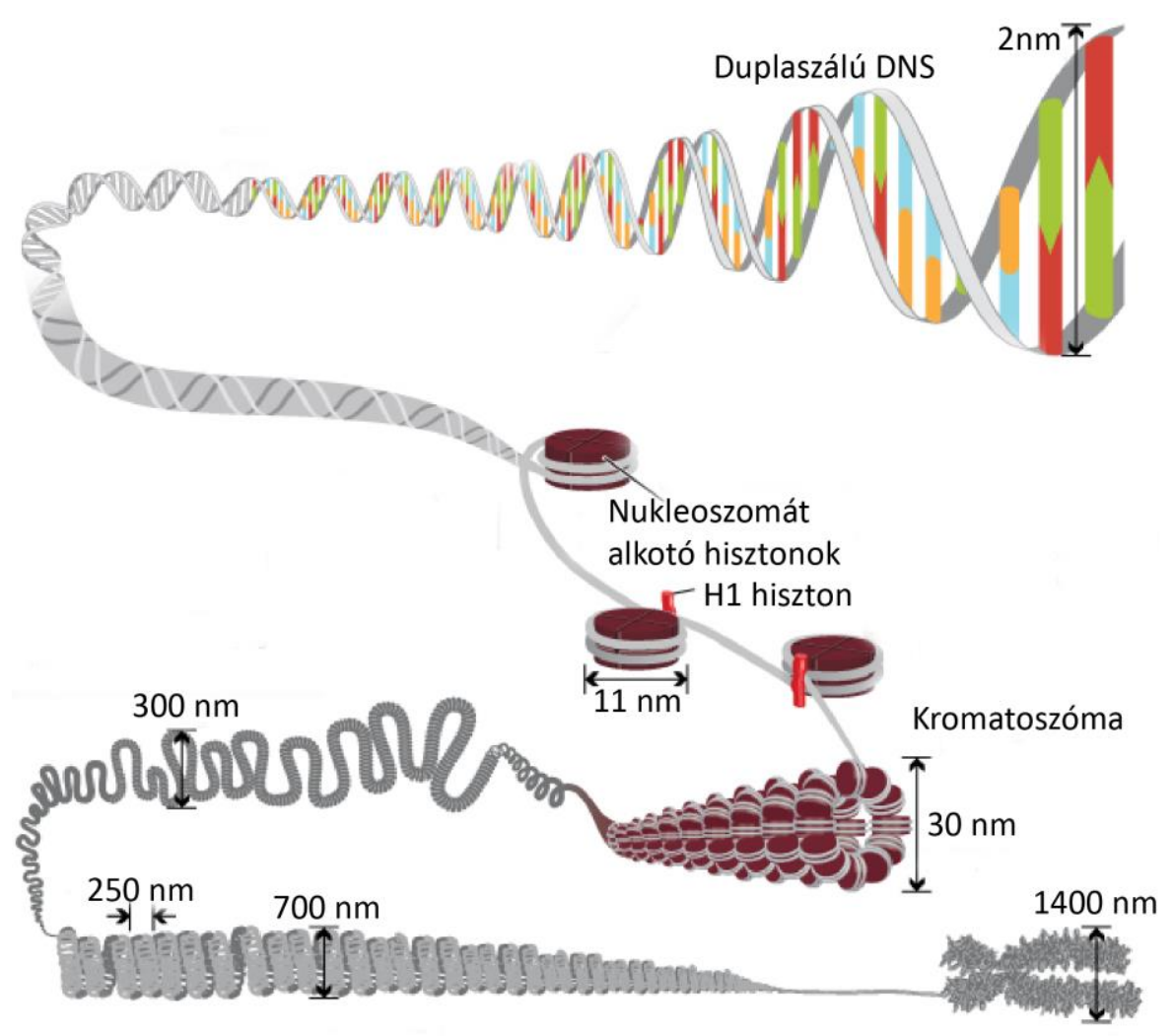

2. ábra: A kromatinállomány szerveződési szintjei. Az ábra a kromatinállomány különböző szerveződési szintjeit ábrázolja sematikusan. Benjamin A. 2004 alapján módosítva [3].

\subsection{Hisztonok poszttranszlációs módosításainak hatása a kromatin szerkezetre}

A nukleoszómákat alkotó hisztonok N-terminális régióin különböző kovalens poszt-transzlációs módosítások mehetnek végbe, melyek hozzájárulnak a kromatin szerkezet módosulásához. A hisztonok módosításai által jön létre a nyitott és zárt kromatin szerkezet közötti átalakulás, ami hatással van a génmüködés szabályozására is. A hisztonok pozitív töltéssel, a DNS pedig negatív töltéssel rendelkezik. Ha a hiszton fehérjék oldalláncain acetiláció történik, akkor a hiszton pozitív töltések száma csökken, és a DNS, valamint a hiszton fehérjék közötti kölcsönhatás gyengül, így egy nyitottabb kromatin szerkezet jöhet létre [4]. Ezt a feltételezést támasztja alá az a kísérlet is, melynél megfigyelték, hogy a H4K16 acetilációja akadályozza a kromatin magasabb szintü kondenzáltságát [5]. 
A hiszton módosításokat különbözö nem hiszton fehérjék ismerik fel az erre specifikus doménjükkel. Számos olyan domént azonosítottak, melyek szerepet játszanak a módosítások felismerésében. A hiszton metilációt felismerő domének közé tartoznak a Chromo- (chromatin organization modifier), Tudor- (Transcription factor-like), vagy a PHD- (plant homeodomain) domén, míg az acetiláció felismerésében a Bromodomén játszik szerepet [6].

A hisztonok poszttranszlációs módosításait felismerő fehérjék általában specifikusak az adott módosításokra [például a BPTF (Bromodomain and PHD fingercontaining transcription factor) fehérje Chromodoménje a H3 4-es lizinjén lévő trimetilációt ismeri fel]. Bizonyos poszttranszlációs módosítások hatással vannak a közeli hisztonokon lévő fehérjék kötődésére [például a H3 szerin 10-es foszforilációja befolyásolja a HP1 (Heterochromatin protein 1) kötődését a H3 9-es metilált lizin részeken] [7].

Ezen a mechanizmuson alapul a hiszton kód hipotézis is, mely szerint a hisztonok oldalláncain megjelenő módosítások egyfajta kódot jelentenek, melyeket bizonyos fehérjék olvasnak le, ezáltal lehetővé teszik a kromatin szerkezet módosítását.

\subsection{Hiszton acetiltranszferázok}

A hiszton acetiltranszferázok (HAT) olyan enzimek, melyek az acetil koenzim Aról a hisztonok lizin aminosavjaira helyeznek át acetil csoportot. A HAT fehérjék szubcelluláris lokalizációjuk alapján két csoportba sorolhatók: az A típusú hiszton acetiltranszferázok a nukleoszómákban található hiszton fehérjék módosításaiban vesznek részt, míg a $\mathrm{B}$ típusú hiszton acetiltranszferázok a citoplazmában vannak jelen és az újonnan szintetizálódó hisztonok módosításaiban játszanak szerepet. A hiszton acetiltranszferázokat katalitikus doménjük alapján is csoportosíthatjuk. Eszerint a HAT fehérjéket a következő fehérjecsaládokba sorolhatjuk: SRC (szteroid receptor koaktivátor 1), MYST (Morf, Ybf2, Sas2, Tip 60 tartalmú), GNAT (Gcn5 tartalmú Nacetiltranszferáz), p300/CBP (CREB-binding protein) és TAF1 (TBP-vel asszociált faktor 1) [8]. 


\subsection{GCN5 tartalmú hiszton acetiltranszferáz komplexek}

A Tetrahymena thermophila-ban azonosítottak először a HAT enzim aktivitással rendelkező proteint, a P55-öt. Azóta számos más organizmusban is megtalálták a p55 ortológját, melynek elnevezése az élesztő mutáns fenotípusa alapján a GCN5 (general control nonderepressible 5) lett. Emlős sejtekben a GCN5 fehérjének két variánsát - a rövidebb GCN5S-t és a hosszabb GCN5L fehérjét - figyelhetjük meg. A GCN5 egymagában képes acetilálni a nem nukleoszómális H3 14-es lizinjét [9]. A GCN5 fehérje azonban nem önmagában, hanem különböző típusú HAT komplexben fordul elő, mint például a SAGA (Spt-Ada-Gen5 Aacetyltransferase) vagy az ATAC (ADA-Two-AContaining) komplexekben, ezáltal képes acetilálni a nukleoszómális hisztonokat is [10] [11] [12].

A SAGA (Spt-Ada-Gcn5 Aacetyltransferase) komplex több funkcionális modulból áll. A TAF modul és az SPT modul mellett rendelkezik még deubiquitinációs és acetilációs modullal is. Az élesztő sejtekben található SAGA acetilációs modulja az yGCN5, az yADA2 (alteration/deficiency in activation-2), az yADA3 (alteration/deficiency in activation-3) és az ySGF29 (SAGA-associated factor 29) fehérjéket tartalmazza. Az ySPT3 (suppressor of Ty element 3) és az ySPT8 fehérjék a TBP-vel (TATA binding protein) képeznek kölcsönhatást. A deubiquitinációs modul felépítésében az yUBP8 (ubiquitinspecific processing protease 8), az ySUS1 (S1 gene upstream of ySa1), az ySGF11 (SAGA-associated factor 11) és az ySGF73 vesz részt. További alegységek, mint az ySPT7, az ySPT8, az ySPT20, az yADA1 (alteration/deficiency in activation-1), az yTAF5 (TATA box-binding protein-associated factor 5), az yTAF6, az yTAF9, az yTAF10 és az yTAF12 a komplex strukturális felépítésében játszanak fontos szerepet (I táblázat) [13] [14]. A hiszton-fold doménokat tartalmazó yTAF fehérjék közül az yTAF10 az ySPT7 fehérjével kapcsolódik, továbbá az yTAF12 az yADA1 fehérjével alakít ki kölcsönhatást [15]. A hiszton-fold doménnel rendelkező fehérjék mellett a WD40 ismétlődéseket tartalmazó yTAF5 és ySPT8 is részt vesz a fehérje-fehérje kölcsönhatások kialakításában [16]. A magasabb rendü eukarióta szervezetben előforduló SAGA komplexek összetétele hasonlít az ySAGA komplex felépítésére. A GCN5-höz hasonlóan konzerváltságot mutatnak a TAF5, TAF6, TAF9, TAF10 és az ADA2 fehérjék is [17] [18] [19]. Jellemző ezekre a fehérjékre, hogy az evolúciós fejlődés során több változatuk jött létre, amelyek különböző transzkripcióban szerepet játszó komplexek alegységei. Emlős sejtekben a TAF5L és a TAF6L fehérjék a SAGA komplexben, míg a TAF5 és a TAF6 fehérjék a 
TFIID-ben (Transcription factor II D) fordulnak elő [20]. A Drosophilában található dTAF10, illetve dTAF10b fehérjék valószínüleg szintén két különböző komplexben fordulnak elő [19]. Irodalmi adatok alapján feltételezhető, hogy a dTAF10 a dTFIID, a dTAF10b a dSAGA komplex részét képezi [21]. Humán sejtekben azonban a hTAF9 és a hTAF9b része a SAGA és a TFIID komplexeknek is [18].

Élesztőben egy ADA2 fehérje van, mely része az ADA és a SAGA komplexnek is [22]. A Drosophila és a humán sejtekben két közeli rokon ADA2 fehérje található, a dADA2a és a dADA2b. A biokémiai vizsgálatok azt mutatták, hogy a dADA2b a dSAGA, a dADA2a viszont a 0,7 MDa dATAC komplex tagja [23] [24] [25].

Az ATAC komplex hiszton acetiltranszferáz modulját az ADA2a, ADA3, GCN5 és az SGF29 alkotják. Ezek közül az ADA3, a GCN5 és az SGF29 fehérjék a SAGA és az ATAC közös alegységei (I táblázat). A két komplex HAT moduljaiban közös GCN5 fehérje a Bromodoménján keresztül ismeri fel a hisztonok acetilált részeit [26]. A közös alegységek közül az SGF29 a trimetilált részek felismerésében vesz részt.

Az ADA2 fehérjék ZNF (Zinc finger), SANT (Swi3-Ada2-NCoR-TFIIIB) és SWIRM (Swi3p-Rsc8p-Moira) doménnal rendelkeznek, melyek különböző funkciót töltenek be a kromatin szabályozásában. Az ADA2a fehérje SWIRM doménján keresztül kötődik a hisztonok acetilált részeihez, majd indukálja az ACF (ATPdependent chromatin-assembly factor) komplex H1-hez való kötődését, ami a kromatin állomány átrendeződéséhez vezet [27]. A SANT és a Zn-ujj domének a GCN5 és az ADA2 fehérjék közötti kapcsolatban vesznek részt [28]. Az ADA fehérjék tartalmaznak még konzervált ADA boxokat, melyek szerkezete hasonlít más fehérjékben is előforduló hiszton-fold doménra [25].

A közös alegységek és az ADA2a fehérjéken kívül az ATAC komplex további 8 alegységét azonosították humán sejtekben: ATAC1 (ATAC component 1), ATAC2 (ATAC component 2), HCF1 (Host cell factor 1), WDR5 (WD repeat-containing protein 5), NC2ß (Negative cofactor 2-béta), YEATS2 (YEATS domain-containing protein 2), MBIP (MAP3K12-binding inhibitory protein 1), CHRAC17 (Chromatin accessibility complex $17 \mathrm{kDa}$ protein) [29] (I. táblázat). Drosophilában a humán ATAC komplexet alkotó fehérjék ortológjai mellett további 1 alegységet találtak, az ATAC3 fehérjét [29]. Az ATAC komplex moduláris felépítése eltér a SAGA-tól. Az ATAC nem rendelkezik deubiquitinációs modullal, SPT modullal, és a TAF fehérjékből álló modul is hiányzik. További különbség az is, hogy az ATAC komplexben nemcsak a GCN5, hanem az ATAC2 fehérje is rendelkezik hiszton acetiltranszferáz aktivitással [30]. Azonban az 
ATAC komplexen belül is jelen vannak hiszton-fold domént, illetve WD40 domént tartalmazó fehérjék, melyek a komplex stabilitásának fenntartásában vesznek részt. Az ATAC komplex WD40 domén tartalmú fehérjéi közé tartozik a humán sejtekben jelenlévő WDR5 (WD repeat-containing protein 5), illetve Drosophilában a WDS (will die slowly) fehérje, amely a hWDR5 ortológja. Az ATAC komplex hiszton-fold domént tartalmazó fehérjéi az NC2ß, a YEATS2 és a CHARC14 [29].

Az ATAC és a SAGA komplex nemcsak felépítésében különbözik egymástól. A Drosophilában előforduló dSAGA, illetve dATAC GCN5 tartalmú HAT komplexek hiszton acetiltranszferáz aktivitásának specificitása eltérő. Drosophila melanogaster-ben a dSAGA alegység dADA2b fehérje hiányában a $\mathrm{H} 3$-as hiszton 9-es és 14-es lizin acetilációjának csökkenését figyelték meg. A dADA2a fehérje hiányában viszont a H4-es hiszton 5-ös, illetve 12-es lizinjének acetilációja csökkent [31] [32]. Ugyanakkor az dADA2 fehérjék a H3K18-, H4K8- és a H4K16- acetilációját nem befolyásolják [31] [32].

\begin{tabular}{|c|c|c|c|c|}
\hline & \multicolumn{3}{|c|}{ SAGA } & \\
\hline & ySAGA & dSAGA & hSTAGA & \\
\hline \multirow{3}{*}{$\begin{array}{l}\text { SAGA és ATAC } \\
\text { komplex Közös } \\
\text { alegységek }\end{array}$} & yGCN5 & dGCN5 & $\begin{array}{l}\text { hGCN5(KAT2A) } \\
\text { és PCAF }\end{array}$ & \multirow{4}{*}{$\begin{array}{c}\text { Acetilációért } \\
\text { felelős } \\
\text { alegységek }\end{array}$} \\
\hline & yADA3 & dADA3 & hADA3 & \\
\hline & ySGF29 & dSGF29(CG30390) & hSGF29(CCDC101 & \\
\hline \multirow{16}{*}{$\begin{array}{c}\text { SAGA specifikus } \\
\text { alegységek }\end{array}$} & yADA2 & $\mathrm{dADA} 2 \mathrm{~b}$ & hTADA2b & \\
\hline & yADA1 & dADA1 (CG31866) & hTADA1 & \multirow{6}{*}{ SPT modul } \\
\hline & yTRA1 & dTRA1 & hTRRAP & \\
\hline & ySPT8 & - & - & \\
\hline & ySPT7 & dSPT7(CG6506) & hSPT7(SUPT7L) & \\
\hline & ySPT3 & dSPT3 (CG3169) & hSPT3 (SUPT3H) & \\
\hline & ySPT20 & dSPT20(CG17689) & hSPT20 (p38IP) & \\
\hline & yTAF12 & dTAF12 & hTAF12 & \multirow{5}{*}{ TAF modul } \\
\hline & yTAF10 & dTAF10 & hTAF10 & \\
\hline & yTAF9 & dTAF9 & hTAF9 & \\
\hline & yTAF6 & dTAF6 & hTAF6 & \\
\hline & yTAF5 & dTAF5 & hTAF5 & \\
\hline & ySGF73 & dCG9866 & hATXN7 & \multirow{4}{*}{$\begin{array}{c}\text { Deubiquitinációért } \\
\text { felelős } \\
\text { alegységek }\end{array}$} \\
\hline & ySGF11 & dSGF11 & hATXN7I3 & \\
\hline & ySUS1 & $d E(Y) 2$ & hENY2 & \\
\hline & yUBP8 & dNONSTOP & hUSP22 & \\
\hline
\end{tabular}




\begin{tabular}{|c|c|c|c|}
\hline \multicolumn{3}{|c|}{ ATAC } & \\
\hline & dATAC & hATAC & \\
\hline \multirow{3}{*}{$\begin{array}{c}\text { SAGA és ATAC } \\
\text { komplex közös } \\
\text { alegységei }\end{array}$} & dGCN5 & hGCN5(KAT2A) és PCAF & \multirow{4}{*}{$\begin{array}{c}\text { Acetilációért } \\
\text { felelős } \\
\text { alegységek }\end{array}$} \\
\hline & dADA3 & hADA3 & \\
\hline & dSGF29(CG30390) & hSGF29(CCDC101 & \\
\hline \multirow{10}{*}{$\begin{array}{l}\text { ATAC specifikus } \\
\text { alegységek }\end{array}$} & dADA2a & hADA2a & \\
\hline & dATAC3 & - & \\
\hline & dATAC2(CG10414) & hATAC2(CSRP2BP) & \\
\hline & dATAC1 & hATAC1(ZZZ3) & \\
\hline & dHCF1(CG1710) & hHCF1(HCFC1) & \\
\hline & dWDS & hWDR5 & \\
\hline & $d N C 2 \beta$ & hNC2 $\beta$ (DR1) & \\
\hline & dYEAST2(D12) & hYEAST2 & \\
\hline & dMBIP(CG10238) & hMBIP & \\
\hline & dCHRAC14 & hCHRAC17(POLE3) & \\
\hline
\end{tabular}

I táblázat: ATAC és SAGA komplex alegységek ortológjai a különböző organizmusokban. Felső táblázat: A Saccharomyces cerevisiae- (ySAGA), Drosophila melanogaster- (dSAGA) és a Homo sapines-ben (hSAGA) található SAGA alegységek ortológjai. Az alsó táblázat a humán, valamint a Drosophila sejtekben található ATAC komplex alegységeinek az ortológjait mutatja. Spedale G. 2012 alapján módosítva [13].

\subsection{Eukarióta transzkripció iniciációja}

A transzkripció minden élő sejtre jellemző folyamat. Az eukariótákban a transzkripció azonban komplexebb módon megy végbe, mint a prokarióták esetében. Míg a prokarióta sejtekben egy RNS polimeráz vesz részt a transzkripcióban, addig az eukarióta sejtekben többféle RNS polimeráz van jelen. Az eukarióta sejtekben lévő RNS polimeráz II a fehérjéket kódoló gének transzkripciója mellett, a mikroRNS és az snoRNS-ek szintézisében is részt vesz. Az 5,8S, 18S, 28S rRNS-ek transzkripcióját az RNS polimeráz I végzi. Az RNS polimeráz III a tRNS, az 5S rRNS, valamint az snRNS transzkripciójában játszik szerepet. Ezek mellett növényekben megtaláljuk még az RNS polimeráz IV-et és Vöt is, melyek az siRNS-ek szintézisében vesznek részt. További különbség az is, hogy prokariótákban az RNS polimeráz a szigma faktorral együtt képes kötődni a gének promóter szakaszaihoz. Az eukariótákban azonban egy bonyolultabb felépítésü fehérje komplex szükséges ahhoz, hogy az RNS polimeráz kötődni tudjon a gének promóter régióihoz és a transzkripció elindulhasson. Ez a fajta komplexitás az eukarióták számára lehetővé teszi az egyedi sejtszintű és a szövetspecifikus génexpresszió szabályozását. 
Az eukarióta transzkripció szabályozása több szinten megy végbe. A gének promóter szakaszai több konzervált DNS szekvenciát tartalmaznak, melyeket különböző transzkripciós faktorok ismernek fel. Eukarióta promótereknél az egyik leggyakrabban előforduló konszenzus szekvencia a TATA-box, ami a transzkripciós start hely előtt körülbelül 20-30 bázispárnyira található. A TATA-box konszenzus TATAAT szekvenciából áll, amit a TFIID komplexben található TBP (TATA binding protein) ismer fel. A TATA-box jelenléte nem minden esetben szükséges ahhoz, hogy a transzkripciós faktorok a promóter szekvenciákhoz tudjanak kötődni. Élesztőben megfigyelték az általános transzkripciós faktorok jelenlétét a TATA-box nélküli promóter szekvenciákon is [33] [34]. A TATA-box mellett további konzervált „,core” promóter elemeket találhatunk. Ilyen konzervált szekvenciák például a TFIIB által felismert szakaszok (TFIIB recognition elements, BRE), melyek a transzkripcióra pozitív, illetve negatív hatással is lehetnek [35]. A BRE elemeken kívül a „core” promóter részeken előfordulhatnak még a transzkripciós start pont környékén az iniciátor régió (InR elemek) és downstream promóter elem is, ami a start helytől számítva 20-30 nukleotidnyi távolságban helyezkedik el. A „core” promóter szakaszok mellett más transzkripciót szabályzó szekvenciák is előfordulnak az eukarióta genomban. Ezek képesek távolabbról is szabályozni az egyes gének transzkripcióját. Ilyenek például az úgynevezett enhancer szekvenciák. Az enhancer szekvenciákhoz kötődő fehérjék által a gének transzkripciójának mértéke fokozódik. Élesztőben az UAS enhancer szakaszokat figyelték meg, melyek a szabályozott gén elött a promóter elemektől nagy távolságra vannak [36]. Az enhancer elemek a magasabb rendű eukarióta szervezetekben a gének kódoló régiójához képest 5' és 3' irányban is elhelyezkedhetnek. Ezen kívül ismerünk silencer elemeket is, melyekhez a transzkripciót gátló fehérjék kötődnek. A gén promóter régiójától távol lévő enhancer, illetve silencer elemek, valamint a preiniciációs komplex közötti kapcsolatot a mediátor komplex teremti meg. A Saccharomyces cerevisiae-ben előforduló mediátor komplex 25 alegységből áll, melynek ortológjait más organizmusokban is azonosították. Magasabb rendü eukariótákban további 5 alegységet figyeltek meg [37]. A több alegységes komplex fej, farok és nyaki részre különül el, melynél a feji rész a preiniciációs komplexszel (PIC-el) alakít ki kapcsolatot, a farki rész pedig specifikus transzkripciós faktorokkal létesít kölcsönhatást. Az egyik modell szerint a nagyobb távolságokban lévő cisz szabályzó elemek közvetve a hozzájuk kötődő fehérje, valamint a mediátor komplex kölcsönhatása révén tudják befolyásolni a különböző gének transzkripcióját [38]. A mediátor, valamint az enhancer elemhez kötődő aktivátor fehérje kölcsönhatása révén a DNS meghajlik, ezáltal egy DNS hurok alakul ki, mely során a 
szabályozandó promóter szakasz fizikailag közelebb kerül az aktivátor fehérjéhez, ezzel elősegítve a transzkripciót [38].

A megfelelő hosszúságú transzkriptum képződéséhez a transzkripció több lépésből álló összehangolt szabályozására van szükség. Első lépésben a PIC összeszerelődése történik meg. Az általános transzkripciós faktorok közül először a TFIID komplex kapcsolódik, mely a promóter szakaszok TATA szekvenciáihoz kötődő TBP-ből, valamint TBP-hez kötődő TAF (TBP associated factor) fehérjékből áll. A TFIID kötődése során a TBP kötődik a TATA-box kis árkához, ezzel 90 fokos hajlást idéz elő a DNS szálon [39]. A TFIID után a TFIIA kapcsolódik, melynek feladata a TBP-DNS komplex stabilizálása. Ezt követően a TFIIB kapcsolódik a promóter régióhoz, amely tovább erősíti a TBP-DNS kapcsolatot. A TBP, TFIID, TFIIA, TFIIB kötődésével kialakul az upstream promóter komplex, majd a TFIIF az RNS polimeráz II komplexszel együtt kötődik az upstream promóter komplexhez. A TFIIF stabilizálja a preiniciációs komplexet, valamint gátolja az RNS polimeráz II és a DNS közötti nem specifikus kötődést, ezzel kialakul az úgynevezett ,core” PIC. A következő lépésben a TFIIE és a TFIIH kötődik a preiniciációs komplexhez, melyek a DNS széttekeréséért felelősek a promóter szakaszokon.

Először a TFIIE kötődik, mely elősegíti a TFIIH kötődését, ezzel kialakul a zárt

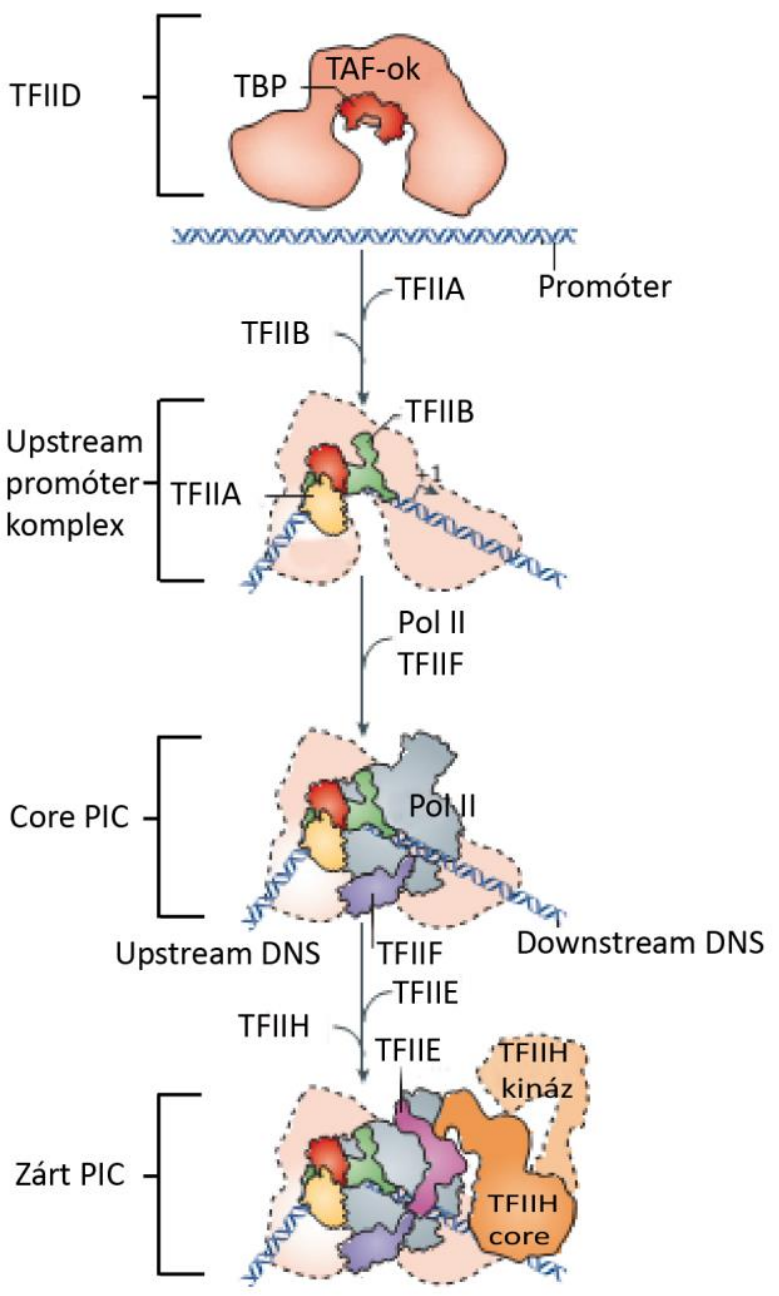

3. ábra: A Preiniciációs komplex összeszerelődésének sematikus ábrázolása.

Elöször a TBP-böl és TAF fehérjékből álló TFIID komplex kötődik a gének promóter szakaszaihoz. A TBP-DNS komplexet a TFIIB és TFIIA stabilizálja. Kialakul az Upstreampromóter komplex, melyhez kapcsolódik a TFIIF-RNS polimeráz II komplex. Ezáltal létrejön a Core Preiniciációs komplex (Core PIC). Végül a TFIIE és TFIIH kapcsolódásával kialakul a zárt preiniciációs komplex (Zárt PIC). Sainsbury S 2015 alapján módosítva [39]. 
preiniciációs komplex (3. ábra). A TFIIH komplexnek kináz, valamint helikáz aktivitása is van. ATP felhasználásával a TFIIH a transzkripciós start pont környékén széttekeri a DNSt, ezáltal kialakul a transzkripciós buborék. Ezt követően a TFIIH CDK7 (cyclin-dependent kinase 7) alegysége foszforilálja az RNS polimeráz II C terminális doménjét az 5-ös szerin aminosavon, ezután kezdődhet el a transzkripció következő fázisa [39]. A transzkripció elkezdése után az RNS polimeráz körülbelül 20-60 bázispárnyi RNS szintézisét követően megáll. Ebben a fázisban történik meg 7-metilguanozin „sapka” elhelyezése a szintetizálandó RNS 5' végén. A folyamat szabályozásában a DSIF (DRB sensitivityinducing factor) és a NELF (negatív elongációs faktor) vesznek részt, melyek kötődnek az RNS polimerázhoz, és gátolják a transzkripció elongációját. Ahhoz, hogy az RNS polimeráz tovább tudja folytatni az RNS szintézisét, a P-TEFb (positive transcriptional elongation factor b) CDK9 alegysége foszforilálja az RNS polimeráz II C-terminális doménjét a 2-es szerin aminosavon, majd a DSIF és a NELF fehérjéket is foszforilálja.

Ezután a foszforilált NELF leválik a RNS polimeráz II komplexről, a foszforilált DSIF pedig segíti a transzkripció elongációját [40]. A transzkripció befejező lépése a termináció, mely során az RNS polimeráz II leválik a DNS-ről. Az előbb említett szabályozó mechanizmusokon kívül még számos más szabályozó útvonal ismert, melyek hozzájárulnak az eukarióta génexpresszió többszintű vezérléséhez.

\subsection{TFIID}

A TFIID több funkcióval rendelkező transzkripciós faktor, mely fontos szerepet tölt be a promóter szakaszok felismerésében, a PIC összeszerelődésében, valamint a kromatin szerveződésében is [41] [42]. A TFIID egy TBP fehérjét és 13-14 TAF-ot tartalmaz. A különbözö élőlényekben a TFIID felépítésénél nagyfokú konzerváltságot figyelhetünk meg. Saccharomyces cerevisiae-ben a TFIID lebenyes szerkezetü, 14 TAF fehérjéből és egy TBP-böl áll. Az élesztő TFIID-n belül 5 nagyobb lebeny különböztethető meg (A, B, C1, C2 és D lebeny), melyek egy satuhoz hasonló szerkezetet képeznek [43]. Az élesztő TFIID központi részében előforduló yTAF5 és a hiszton-fold doménnal rendelkező yTAF4, yTAF6, yTAF9, yTAF10 és az yTAF12 fehérjék két kópiában fordulnak elő és szimmetrikus szerkezetet alkotnak [43] [44].

A humán TFIID felépítése hasonló az élesztőben található TFIID-hez, azonban némi különbség van a TFIID központi részét felépítő TAF-ok összetételében. A központi hTAF-ok (hTAF4, hTAF5, hTAF6, hTAF9 és hTAF12) itt is két kópiában fordulnak elő és 
szimmetrikus szerkezetet alkotnak [45]. A hTFIID szerkezete nem teljesen szimmetrikus. Az összeszerelődés első lépéseiben létrejön egy szimmetrikus szerkezet, melyet a két hTAF5-, két hTAF6-hTAF9 heterodimer és két hTAF4-hTAF12 heterodimer alkot. A core TFIID szimmetriáját az egy kópiában jelenlévő hTAF8-hTAF10 heterodimer töri meg. A hTAF8-hTAF10 heterodimer a citoplazmában alakul ki, és az importin fehérjén keresztül jut a sejtmagba, majd a többi hTAF fehérjével együtt kialakul a core hTFIID [46] [47]. Ehhez a 7 TAF fehérjéből álló komplexhez kapcsolódik a TBP és a többi hTAF fehérje is, melyek egyszer fordulnak elö a komplexben [45] (4. ábra). A Drosophila, valamint a humán TFIID felépítése nagyon hasonlít egymáshoz. A TFIID központi részét felépítő TAF fehérjéket először Drosophilában azonosították [48]. A Drosophila és a humán TFIID a központi alegységeket tekintve nem különbözik egymástól, azonban még nem tisztázott, hogy a Drosophilában előforduló dTAF10 hogyan befolyásolja a dTFIID stabilitását. A központi dTAF fehérjék, a dTAF4, a dTAF5, a dTAF6 és a dTAF12 egy stabil szubkomplexet alkotnak, majd ehhez kapcsolódik a többi dTAF fehérje, valamint a dTBP is, és kialakul a holo dTFIID komplex.

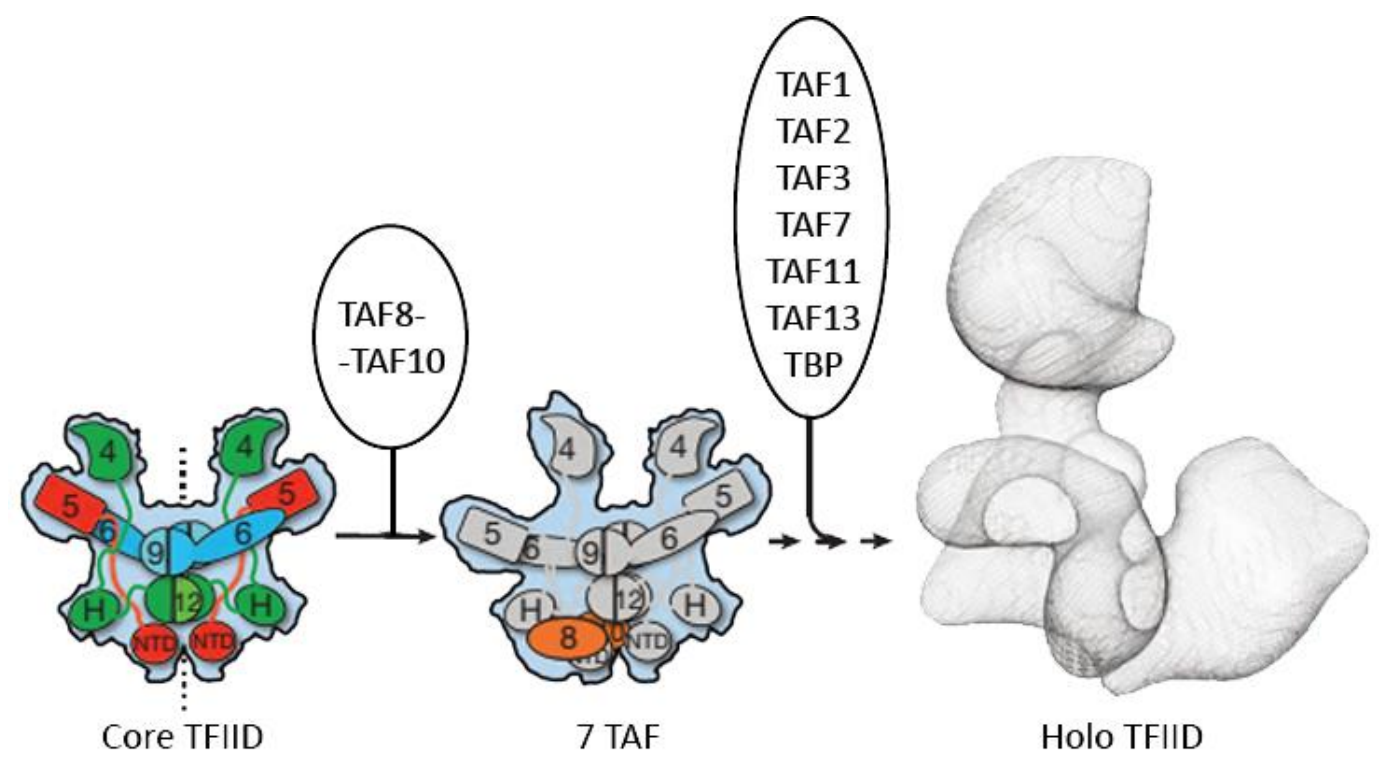

4. ábra: TFIID összeszerelődése humán sejtekben. A baloldali ábra a szimmetrikus „core” TFIID-t jelöli, mely a HF (hiszton-fold) doméneket tartalmazó hTAF4-hTAF12, hTAF6-hTAF9 dimerekből, valamint a hTAF5 fehérjéböl áll. A hTAF8-hTAF10 megtöri a szimmetriát és létrejön a 7TAF fehérjéből álló core TFIID. Később a TBP és a többi TAF fehérje is kapcsolódik a core komplexhez, ezáltal kialakul a holo TFIID. Bieniossek C 2013 alapján módosítva [45]. 


\subsection{A TAF fehériék elnevezése és ortológjai különböző organizmusokban}

Az első TAF fehérjéket 1991-ben Drosophila, valamint humán sejtekben írták le [49] [50]. A TAF fehérjéket először egy TBP-t tartalmazó stabil komplex tagjaiként azonosították és elnevezésük a molekulatömegük alapján történt. Azóta számos organizmusban találtak TAF fehérje ortológokat. A szekvenálási technikák fejlődése miatt egyre több TAF fehérjét fedeztek fel, ezért a könnyebb azonosítás miatt egy új nevezéktant alakítottak ki [51]. Mivel a TFIID központi részét alkotó 13 TAF fehérje (TAF1,2,3,4,5,6,7,8,9,10,11,12,13) nagyfokú konzerváltságot mutat a különböző organizmusokban, az új nevezéktan alapja a TFIID központi részét alkotó konzervált TAF fehérjék molekulatömege. A legnagyobb tömegütől a legkisebb felé haladva rendezték sorba a fehérjéket és kapták azok a növekvő sorszám szerint a TAF1, TAF2, stb. elnevezéseket [51]. A korábban használatos (II)-es utótagot elhagyták a TAF fehérjék jelölésénél, mivel a TAF fehérjék nemcsak az RNS polimeráz II függő transzkripcióban vesznek részt (II. táblázat) [51].

Biokémiai és szekvencia homológia vizsgálatok során több TAF fehérjében is hiszton-fold doméneket azonosítottak. Az élesztőben, ecetmuslicában és Homo sapiensben előforduló TAF9 fehérje ortológjai a H3-hoz hasonló szekvencia részeket tartalmazzák. A nukleoszóma H4-es hiszton fehérjéhez hasonló szekvenciákat a Drosophila, a humán, valamint élesztő TAF6 ortológoknál találjuk meg. A H2A-hoz hasonló szekvencia részeket a TAF12 fehérjék ortológjainál figyelték meg [52]. A TAF fehérjék hiszton-fold doménjai fehérje-fehérje kölcsönhatások kialakításában vesznek részt. Ismert, hogy a Saccharomyces cerevisiae-ben az yTAF3 és az yTAF10 hiszton-fold doménjaikkal heterodimereket képeznek. Drosophilában a dTAF6 és a dTAF9 amino-terminális részein fordulnak elő hiszton-fold domének, melyek alkalmasak a H3, illetve a H4 által kialakított heterodimerhez hasonló fehérje-fehérje kölcsönhatás kialakítására [53] [54]. Humán sejtekben a hTAF6-hTAF9 a H3-H4 hisztonokhoz, a hTAF4-hTAF12 pedig a H2A-H2Bhez hasonló fehérje dimert képeznek. Emiatt korábban feltételezték egy hiszton oktamerhez hasonló szerkezet jelenlétét a humán TFIID komplexen belül [45] [46] [55]. A legújabb modell szerint azonban, a hiszton oktamerhez hasonló struktúra nem alakul ki a TFIID-ben, mert a hTAF dimerek közötti távolság jóval nagyobb, mint a hiszton dimerek közötti távolság. Így a hTAF dimerek között nem alakulhat ki a Van der Waals kölcsönhatás, mint a hiszton dimerek esetében [45]. Humán sejtekben a hTAF8 és a hTAF10 fehérjék is dimert képeznek a hiszton-fold doménjaikon keresztül [56]. Mivel a 
hTAF10 fehérje nem rendelkezik sejtmagi lokalizációs szignállal (NLS), az NLS-t tartalmazó hTAF8 fehérje fontos szerepet tölt be a hTAF10-hTAF8 heterodimer sejtmagi transzportjában [56].

Hiszton-fold doméneket azonosítottak még a TAF11 és a TAF13 esetében is [57] [58] [59] (5. ábra). A TAF fehérjék a hiszton-fold doménen kívül más doméneket is tartalmaznak. A TAF2 N-terminális része egy enzimatikusan inaktív M1 metallopeptidázhoz hasonló domént tartalmaz, mely valószínủleg szintén fehérje-fehérje kölcsönhatások kialakításában vesz részt [60]. A TAF2 C-terminális doménja feltételezhetően a DNS kötésben játszik szerepet [61].

A TFIID legnagyobb alegysége a TAF1, több különböző aktivitással rendelkezik [58] [62]. Mind az N-terminális része, mind a karboxi-terminális része rendelkezik protein kináz aktivitással. A protein kináz aktivitás mellett a TAF1-nek acetiltranszferáz aktivitása is van. In vitro kísérletekkel kimutatták, hogy a TAF1 képes acetilálni a TFIIE $\beta$ alegységét, valamint a TFIIF-et is, emellett a H3, illetve a H4 fehérjéket is [62]. A TAF1 fehérje acetiltranszferáz és kináz aktivitása mellett rendelkezik ubiquitin aktiváló/konjugáló doménnal is, mely a H1 ubiquitilációjában játszik szerepet [63]. Továbbá a TAF1 N-terminális része kapcsolatot alakít ki a TBP-vel, ezáltal szabályozhatja a TBP DNS-hez való kötődését. [64] (5. ábra). A TAF1 C-terminális részében két Bromodomént azonosítottak, melyek acetilált hisztonok felismerésében vesznek részt [65].

A TAF1 mellett a TAF5 fehérjében is több funkcionális domént azonosítottak. A fehérje homodimert képez a TFIID-n belül, a dimer kialakításában a TAF5 N-terminális doménja vesz részt [66]. A karboxi terminális részén WD40 ismétlödéseket figyeltek meg, aminek jellegzetessége a 40 aminosavból álló, nagyrészt triptofánban (W) és aszparaginsavban (D) végződő rövid ismétlődő szekvencia [66] (5. ábra). A WD40 ismétlődő szekvenciák szerepe feltételezhetően a fehérje-fehérje kölcsönhatások kialakításában van, ezt igazolja az a tanulmány is, melynél in vitro kísérletekkel kimutatták, hogy a TAF6 hiszton-fold doménja kölcsönhat a TAF5 WD40 szekvenciáival [67].

Láthatjuk, hogy a TFIID-t felépítő TAF-ok funkciója sokrétü. A TFIID komplex stabilitásának fenntartása mellett részt vesznek specifikus fehérjék foszforilációjában, acetilációjában, ubiquitilációjában, melyek mind hozzájárulnak a transzkripció finoman hangolt szabályozásához. Ezen kívül a TAF fehérjék a promóter szakaszok felismerésében is részt vesznek. A TAF1 és a TAF2 az iniciátor elemek felismerésében játszik szerepet. 
Az MTE, valamint a DPE promóter elemek felismerésében feltételezhetően a TAF6 és a TAF9 fehérjék vesznek részt [68] [69].

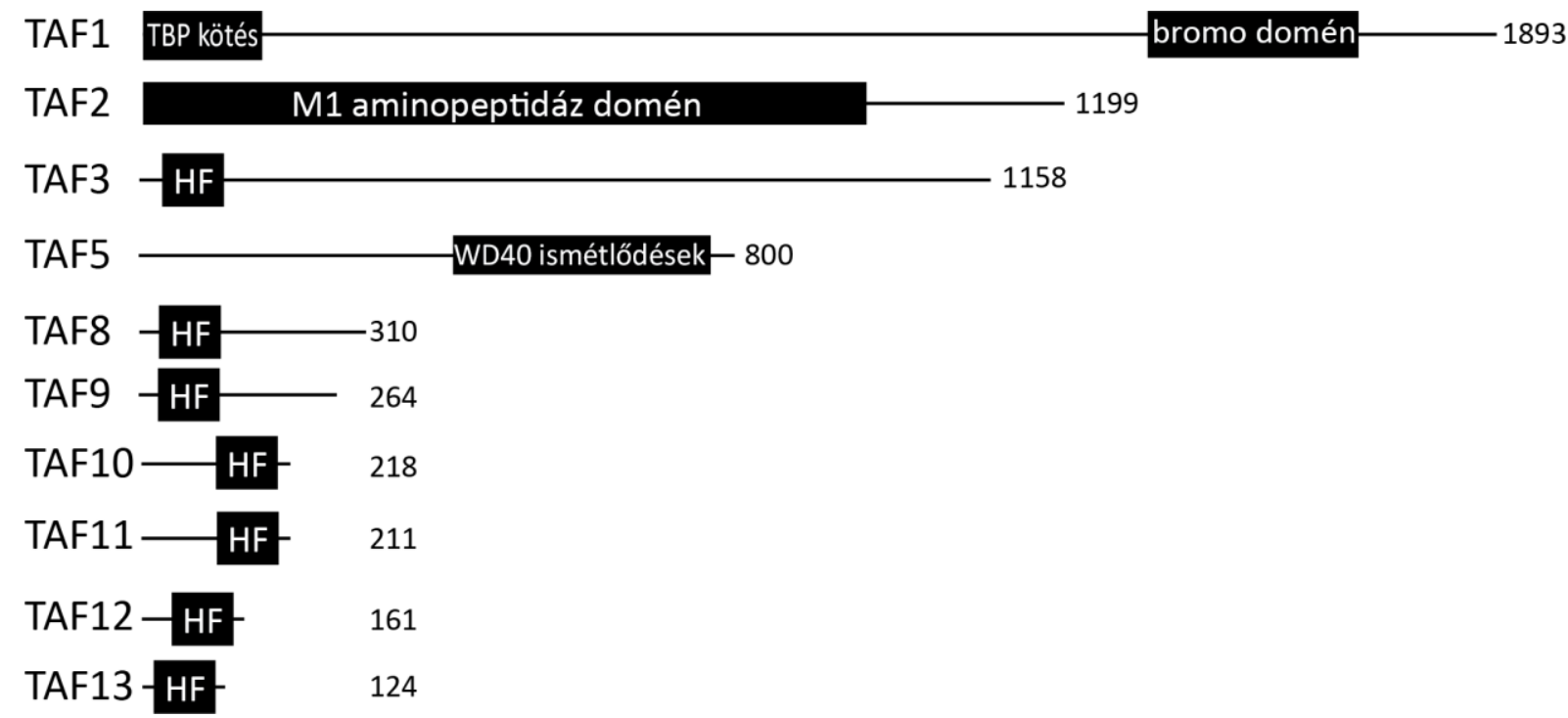

5. ábra: TAF fehérjék doménjainak ábrázolása sematikusan. A fekete téglalapok a fehérjéken a doménokat jelölik. A HF: hiszton-fold domént jelöli. Maja Malkowska 2012 alapján módosítva [61].

\subsection{A TAF10 fehérjék}

A TAF10 fehérjét számos más TAF fehérjével együtt elöször humán sejtekben azonosították, azóta ortológjait több élőlényben is leírták [70]. A TAF10 fehérje funkciója a különböző organizmusokban eltérő.

Saccharomyces cerevisiae-ben a TAF10 hiánya génexpressziós változásokat, sejt ciklus leállást eredményezett, míg egér embrionális karcinóma sejtekben a TAF10 hiánya a sejt ciklus leállás mellett apoptózist indukált [71] [72] [73]. Caenorhabditis elegans-ban kimutatták, hogy a TAF10 tartalmú TFIID az embrionális transzkripcióban vesz részt [74]. A Caenorhabditis elegans-hoz hasonlóan a TAF10 tartalmú TFIID egerekben is föként az embrionális fejlődés során játszik fontos szerepet. Megfigyelték, hogy a TAF10 hiánya befolyásolja a keratinociták terminális differenciációjában részt vevő gének expresszióját, melyek hozzájárulnak a bör integritásának fenntartásához az egér embrionális fejlődése során. Ugyanakkor a TAF10 hiánya nem okozott változást a felnőtt állatok epidermisz keratinocitáiban [75].

Drosophilában két TAF10 fehérje található, a dTAF10 és a dTAF10b, melyek a humán TAF10 ortológjai [76]. Korábban a dTAF10b fehérjét dTAF16-nak, illetve a 
dTAF10 fehérjét dTAF24-nek nevezték. Mindkét fehérje rendelkezik a TAF10 szupercsaládra jellemző konzervált C-terminális doménnal, N-terminális doménjük azonban különbözö. A két fehérje aminosav sorrendje 48\%-ban megegyezik egymással. A dTAF10b a humán TAF10 aminosav sorrendjével összehasonlítva 54\%-os egyezést mutat, míg a dTAF10 és a hTAF10 közötti hasonlóság 48\% [76]. Mindkét fehérje tartalmazza a hTAF10-re és az élesztő TAF10-re jellemző hiszton-fold domént, melyek az N-terminális részen fordulnak elő [57] (6. ábra). A dTAF10 167 aminosav hosszúságú fehérje, melyet egy 664 nukleotidból álló génszakasz kódol, ami egy 59 nukleotidnyi intronikus szakaszt tartalmaz. Ezzel ellentétben a 146 aminosavból álló dTAF10b fehérjét kódoló 560 nukleotid hosszúságú génszakasz nem tartalmaz intront. A TAF10 és a TAF10b fehérjéket kódoló gének a DNS ellentétes száláról íródnak át. A dTaf10 és a dTaflob gének citológiai helye a második kromoszóma bal karján a 23A5 régió. A gének fej-fej orientációban helyezkednek el az Aph-1 valamint a Colt gének szomszédságában. A dTaflO mellett helyezkedik el a Colt, melynek szerepe van a szárny valamint a trachea rendszer fejlődésében. A COLT fehérje szekvenciája pedig hasonlóságot mutat a mitokondriális acil carnitin carrier (CACT) fehérjével [77]. A dTaf10b mellett elhelyezkedő Aph-1 gén által kódolt fehérjének a Notch szignalizációban van esszenciális szerepe [78].

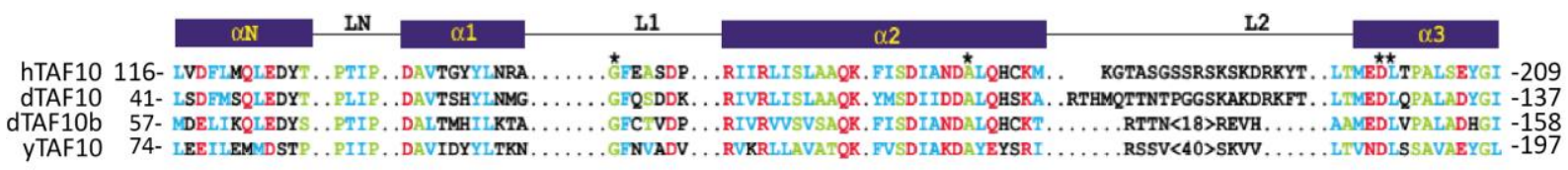

6. ábra: TAF10 fehérjék feltételezett hiszton-fold doménjainak összahasonlítása aminosav sorrend alapján. A $\mathrm{h}$ a Homo sapiens-ben, a d a Drosophila melanogaster-ben, az y a Saccharomyces cerevisiae-ben található TAF10 fehérjéket jelöli. Gangloff YG alapján módosítva [57].

A dTaf10 és $d T a f 10 b$ expressziója az embrionális fejlődés során eltéréseket mutat. A 9. embrionális stádiumban a $d T a f 10 b$ a mezodermális sejtekben, valamint a középbéli primordiumban expresszálódik, a dTaf10 expresszióját viszont az ektoderma, a hasi ideg köteg, valamint az anterior előbél primordiumnál figyelhetjük meg [76]. A későbbi embrionális fejlődés során a $d T a f 10 b$ expressziója kiterjed a közép- és az utóbél sejtjeire és a differenciált izomrostokra is. A dTaf10 expresszióját a későbbi embrionális fejlődés során a központi idegrendszerben, valamint az előbél sejtjeiben figyelték meg [76]. Jelenlegi adatok alapján úgy látszik, hogy a dTaf10, valamint a dTaf10b expressziója nemcsak az embrionális szövetekben, de a felnőtt Drosophilák szöveteiben is különbözik (7. ábra). Feltételezhető, hogy a két fehérje funkciója eltérő. 


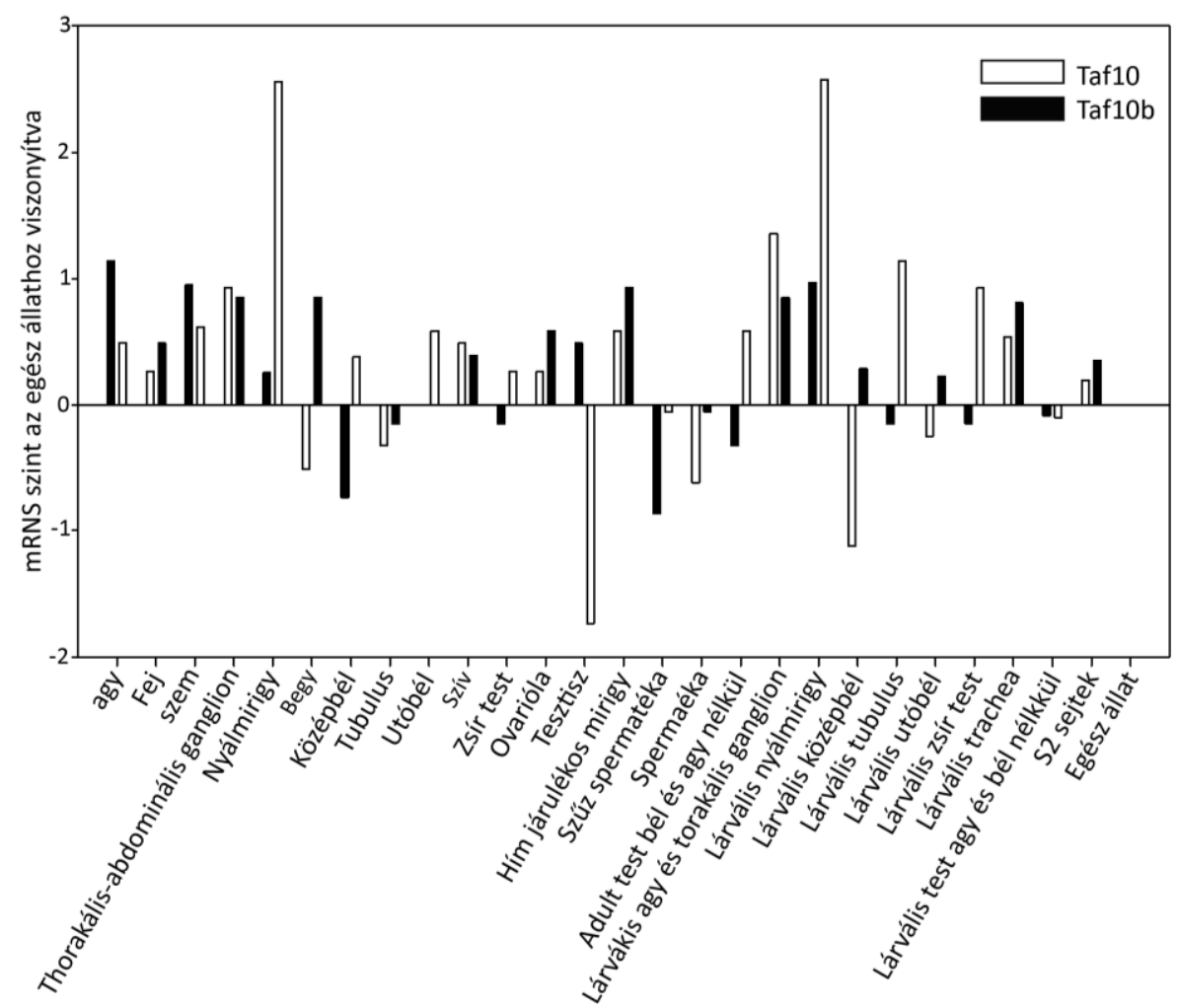

7. ábra: dTAF10 és dTAF10b relatív expressziója a különböző szövetekben. Az ábra a Flyatlas adatai alapján készült [http://flyatlas.org/atlas.cgi].

\subsection{Az ekdizon szabályozása és bioszintézise Drosophila melanogaster-ben}

A Drosophila lárvális fejlődésénél 3 stádiumot különböztetünk meg. A lárva stádiumok közötti vedlések nagyrészt az ekdizon és a juvenilis hormon szabályozásán keresztül valósulnak meg. Az ekdizon hormon mennyisége többször megnövekszik a lárva fejlödése során, ami vedlést indukál. A juvenilis hormon, melynek szintje fokozatosan csökken az egyedfejlődés során, az adott lárva stádium fenntartásában játszik szerepet [79]. Az L3 lárva stádium végén a juvenilis hormon szintje csökken, ezzel szemben megnő az ekdizon szint, és ennek hatására a vándorló L3-as lárvák elöbábot formálnak [80]. Az ekdizon bioszintézise Drosophilában elsődlegesen a gyürümirigyben megy végbe [81]. A gyürümirigy több részből álló összetett szerv, mely a protorakális mirigyből, a corpus allatum-ból és a corpus cardiacum-ból áll. Az ekdizon föként a protorakális mirigyben szintetizálódik, míg a juvenilis hormon termelödése a corpus allatumban történik [82].

Az ekdizon termelődését a prothoracicotropic hormon (PTTH) aktiválja. A PTTH az agyban található bilaterális neuroszekréciós sejtekben termelődik és a corpus allatumban tárolódik, majd a hemolimfába szekretálódik [81]. A szekréciót követően a PTTH neuropeptid a protorakális mirigyben a Torso tirozin kináz receptoron keresztül aktiválja a mitogén-aktivált protein kináz (MAPK) jelátviteli útvonalat, mely fokozza a Halloween 
gének expresszióját [83]. A Halloween gének citokróm P450 enzimeket kódolnak, melyek az ekdizon szintézisében vesznek részt [84]. Az ekdizon stimulálását a PTTH hormon mellett inzulin-szerü növekedési faktorok is okozhatják, melyek az inzulin/PI3K/AKT jelátviteli úton keresztül aktiválják az ekdizon bioszintézishez szükséges gének expresszióját. Az ekdizon szintézisét serkenthetik továbbá aminosavak, glükóz, illetve más tápanyagok is, melyek a TOR jelátviteli útvonalat aktiválják, ezáltal fokozva a Halloween gének transzkripcióját [85].

A rovarok nem képesek a szteránvázas vegyületek de novo szintézisére, ezért az ekdizon szintéziséhez szükséges koleszterint a tápanyagból veszik fel. A koleszterint a Halloween gének által kódolt p450 citokróm enzimek alakítják át 20-hidroxi-ekdizonná [84]. Az ekdiszteroid biokémiai útvonal első lépése a koleszterin dehidrogenálása, melyet a Neverland enzim végez. Ezáltal a koleszterin 7-dehidrokoleszterinné alakul. A további lépésekben a dehidrokoleszterin több, jelenleg még nem ismert kémiai módosuláson megy keresztül, majd 5ß-ketodiollá alakul. Ezt követően a terminális hidroxilációs lépéseket, melyekben az 5ß-ketodiol ekdizonná átalakul, a Phantom, a Disembodied és a Shadow enzimek katalizálják. A Halloween gének nagy része a gyürümirigyben expresszálódik. Az ekdizon a gyürümirigyből a hemolimfába szekretálódik, majd a perifériás szövetekben expresszálódó shade által kódolt P450 monooxigenáz alakítja át 20-hidroxi-ekdizonná [86]. Az ekdiszteroid bioszintetikus útvonalban további enzimek is részt vesznek, melyek a spook, non-molting glossy, spookier, Halloween gének termékei. Jelenleg azonban nem ismert, hogy ezek az enzimek az ekdiszteroid útvonal melyik lépését katalizálják. (8. ábra)

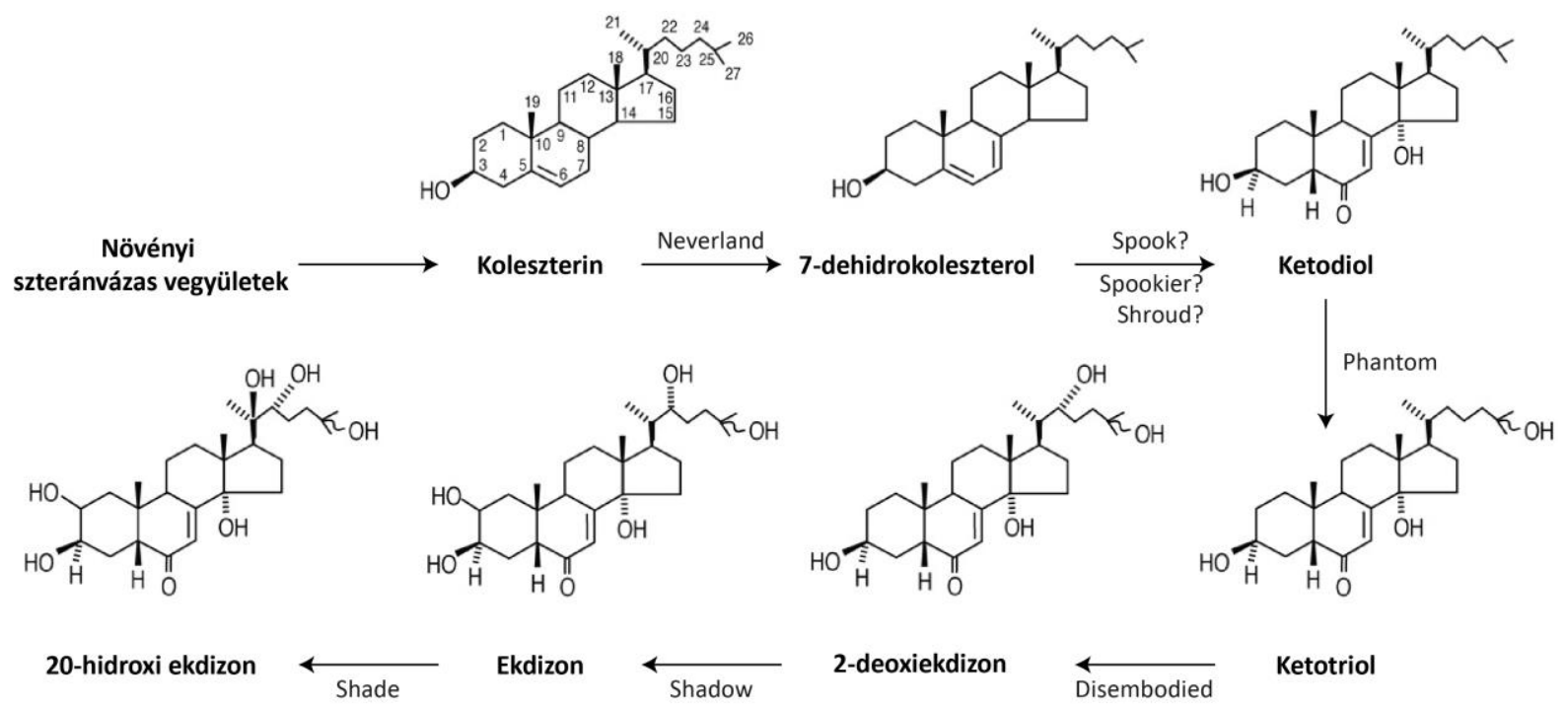

8. ábra: Ekdizon bioszintézis biokémiai útvonala: A Halloween gének (spook, spookier, phantom, disembodied, shadow, shade) által kódolt enzimek reakciói. Lawrence I. Gilber 2003 alapján módosítva [87]. 


\section{Célkitüzések}

Jelenleg kevés információ áll rendelkezésre arról, hogy a dTAF10 és a dTAF10b fehérjék hogyan befolyásolják a Drosophila melanogaster egyedfejlödését. Feltételezésünk szerint a dTAF10/dTAF10b fehérjék befolyásolhatják a dSAGA komplex aktivitását, emellett szerepet játszhatnak a dTFIID összeszerelődésében is. Kérdéseink megválaszolásához az alábbi célokat tủztük ki:

\subsection{Vizsgálni, hogy a dTAF10/dTAF10b fehériék hogyan befolyásolják a Drosophila melanogaster egyedfejlődését}

A dTAF10 és a dTAF10b vizsgálatához korábban P-elem remobilizációjával deléciót hoztak létre, mely érinti a dTAF10-et és dTAF10b-t kódoló génszakaszt. Ezt követően tanulmányozni akartuk, hogy a dTAF10/dTAF10b hiánya milyen hatással van a lárvák egyedfejlődésére.

\subsection{Vizsgálni, hogy a dTAF10/dTAF10b fehérjék hogyan befolyásoliák a dSAGA hiszton acetiltranszferáz komplex müködését}

A dTAF10b a SAGA komplex része, ezért vizsgálni akartuk, hogy a dTAF10/dTAF10b fehérjék hogyan befolyásolják a SAGA specifikus hiszton acetilációt. Ehhez immunhisztokémiával tanulmányozni akartuk, hogyan változik a SAGA specifikus H3K9 és H3K14 acetiláció szintje a dTaf10 ${ }^{d 25}$ Drosophila lárvák politén kromoszómáin a kontrollhoz viszonyítva.

\subsection{Vizsgálni, hogy a dTAF10/dTAF10b fehérjék hogyan befolyásolják a dTFIID komplex összeszerelődését}

Vizsgálni akartuk, hogy a dTAF10/dTAF10b fehérjék hatással vannak-e a TFIID összeszerelődésére, illetve befolyásolják-e a TFIID alegységek fehérje szintjét. Ennek megválaszolására immunhisztokémiával tanulmányozni akartuk, hogy a TFIID alegységek lokalizációja hogyan változik a $d T a f 10^{d 25}$ Drosophila lárvák politén kromoszómáin. Ezen kívül Western blottal tanulmányozni akartuk, hogy a dTAF10/dTAF10b fehérjék hogyan befolyásolják a különböző dTFIID alegységek fehérje szintjét. 


\section{Anyagok és módszerek}

\subsection{Drosophila melanogaster törzsek és keresztezések}

A Drosophila melanogaster vonalakat standard táptalajon $(9,3 \mathrm{~g}$ agar, 61,2 $\mathrm{g}$ kukoricadara, $10 \mathrm{ml}$ 10\% nipagin, 129,4 g glükóz, 32,4 g száraz élesztö/ 1 liter) $25{ }^{\circ} \mathrm{C}$-on tartottuk fent. A $w^{1118}$ Drosophila vonalat alkalmaztuk kontrollként a kísérleteinkhez.

Kísérleteinkben laborunkban korábban előállított $d A d a 2 a^{d 189}$ mutáns Drosophila vonalat használtuk. A $d A d a 2 a^{d 189}$ mutánsok generálása megtalálható a [31] forrásban. Az Ada2a ${ }^{d 189}$ allélt TM6b balanszer kromoszóma segítségével tartottuk fent, mivel az $A d a 2 a^{d 189}$ allél homozigóta formában L3, illetve bábletális. Az Ada2 $b^{d 842}$ deléciót hordozó Drosophila vonalakat korábban laborunkban állították elö. Az allél egy P-elem kiugratással létrehozott 800 bp hosszúságú deléciót tartalmaz, aminek eredményeként a $d A d a 2 b$ első exon és intronikus régiói hiányoznak. A $A d a 2 b^{d 842}$ mutáció homozigóta állapotban báb, illetve kikelés elötti úgynevezett „pharate adult” stádiumban letalitást eredményez [32].

A dTAF10 fehérjék vizsgálatához korábban előállított deléciót hordozó Drosophila melanogaster vonalakat használtam. $P\left\{\right.$ SUPor-P\}Taf $10^{K G 07031}$ P-elem mobilizálásával 900 bp hosszúságú deléciót hoztak létre, mely mind a dTAF10 mind a dTAF10b kódoló régióit érinti, viszont a szomszédos Aph, illetve Colt génekre nem terjed ki. (9. ábra)

Az alábbi RNS interferencia vonalak a „Vienna Drosophila Resource Center (VDRC)”-ből származnak:

dTaf5 $5^{R N A i}$ :

http://stockcenter.vdrc.at/control/product/ VIEW_INDEX=0/ VIEW_SIZE=100/ product _id $=45955$

dTaf8 RNAi :

http://stockcenter.vdrc.at/control/product/ VIEW_INDEX=0/ VIEW_SIZE=100/ product $\_$id $=27870$

A dTaf10-re specifikus Drosophila RNS interferencia vonal a National Institute of Genetics Genetic Strain Research Center-ből származik:

dTaf10 RNAi :

https://www.shigen.nig.ac.jp/fly/nigfly/rnaiDetailAction.do?input=sr\&stockId=2859R-5 
A dTaf5, dTaf8, dTaf10 RNS interferencia kísérletekben az siRNS szövet és fejlődésspecifikus kifejezéséhez UAS-GAL4 rendszert használtunk. Ahhoz hogy a Drosophila minden sejtjében expresszió csökkenést hozzunk létre, w[1118]; +; P\{Act5CGAL4\}/TM6b driver vonalat használtunk. A gyürümirigyben történő RNS interferenciához gyürümirigyre specifikus $w[1118] ; \quad+; \quad P\{P h m-G A L 4 . W T\} / T M 6 b$ driver vonalat alkalmaztunk.

\subsection{Western blot kísérletek}

A Drosophila melanogaster L3-as lárvákat szonikációs pufferben $(50 \mathrm{mM}$ Tris- $\mathrm{HCl}$ pH 7,9, 2 mM EDTA pH 8,0, 50 mM NaCl, 0,5 mM DTT, 10 mM Na-butirát, 1x PIC) homogenizáltuk, a homogenizálás után centrifugáltuk a mintákat (13000 rpm, 5 perc, 25 $\left.{ }^{\circ} \mathrm{C}\right)$. A mintákhoz 2X SDS loading puffert adtunk, mely 20\% glicerint, $100 \mathrm{mM}$ Tris- $\mathrm{HCl}$ pH 6,4, 200 mM DTT, 4\% SDS, 0,2\% brómfenolkéket, 5\% $\beta$-merkaptoetanolt tartalmazott. Ezután a mintákat 6 percen keresztül $100{ }^{\circ} \mathrm{C}$-on denaturáltuk, majd ismét centrifugáltuk (13000 rpm, 5 perc, $25^{\circ} \mathrm{C}$ ), hogy az esetleges kutikula daraboktól megtisztítsuk a fehérje mintát. A minták fehérje koncentrációját Bradford reagenssel határoztuk meg. Az azonos fehérje mennyiségeket tartalmazó mintákat 15\%-os akrilamid SDS PAGE-el választottunk el, ezután elektroblottolással a fehérjéket nitrocellulóz membránra rögzítettük. A nitrocellulóz membránt 5\% tejpor-TBST (10 mM Tris-HCl pH 8,0, $150 \mathrm{mM} \mathrm{NaCl,} \mathrm{0,05 \%}$ Tween-20), illetve 5\% BSA-TBST oldatban 16 órán keresztül blokkoltuk. Ezt követően a nitrocellulóz membránt 3-szor 10 percig TBST oldatban mostuk, majd az elsődleges ellenanyagot tartalmazó 2\% BSA-TBST oldatban a membránt 2 órán át inkubáltuk. Elsődleges ellenanyagként H3 (Abcam ab1791 1:1500), H3 acetilált K14 (Upstate \#07-353 1:300), dTAF1 (1:300 nyúlban termeltetett poliklonális ellenanyag), dTAF5 (1:400 nyúlban termeltetett poliklonális ellenanyag) és dTBP (1:500 nyúlban termeltetett poliklonális ellenanyag) elleni ellenanyagokat használtunk. A dTAF1, dTAF5 és a dTBP ellenanyagok Yoshihiro Nakatani laborjából származnak [17]. Az elsődleges ellenanyag hozzáadása után a nitrocellulóz membránt TBST oldatban mostuk 3-szor 10 percig. A kötődött elsődleges ellenanyagok kimutatásához torma peroxidázzal konjugált IgG elleni ellenanyaggal inkubáltuk a membránt 1,5 órán keresztül. A következő lépésben a membránt 3-szor 10 percig mostuk TBST oldattal, majd Immobilon Western Chemiluminescent HRP Substrate (Millipore) oldattal inkubáltuk 3 percen keresztül. Az így keletkezett kemilumineszcens jelet C-DiGit Blot Scanner segítségével hívtuk elő. 


\subsection{Immunfestések}

A vizsgálni kívánt lárvákat élesztővel kiegészített táptalajon növesztettük. Késői L3 lárvák nyálmirigyeit $20 \mu \mathrm{l}$ 1X PBS (137 mM NaCl, 2,7 mM KCl, 8,1 mM Na $2 \mathrm{HPO}_{4}, 1,76$ $\left.\mathrm{mM} \mathrm{KH}{ }_{2} \mathrm{PO}_{4}, \mathrm{pH} 7,4\right)$ oldatban boncoltuk. A nyálmirigyeket a PBS után 30 másodpercig 1X PBS, 2\% NP-40, 3,7\% formaldehid oldatban fixáltuk. Ezt követően 30 másodpercig $45 \%$ ecetsavat és $3,7 \%$ formaldehidet tartalmazó oldatban permeabilizáltuk, majd 1 percig 45\%-os ecetsavas oldatban inkubáltuk. A nyálmirigyet szilikonizált fedőlemez segítségével fedtük le, ezt követően nagy nyomással szétroncsoltuk a szövetet. Ezután folyékony nitrogénben fagyasztottuk a tárgylemezeket, majd a szilikonizált fedőlemezt eltávolítottuk, és a tárgylemezeket 2 órán keresztül PBST (1X PBS, 0,1\% Tween-20) oldatban inkubáltuk. A preparátumokat 5\% BSA-PBST oldatban 1 órán át blokkoltuk, majd a blokkoló oldatot eltávolítottuk és a preparátumokat 3-szor 10 percig PBST oldattal mostuk. Ezt követően az elsődleges ellenanyagot 2\% BSA-PBST oldatban hígítottuk. Elsődleges ellenanyagként H3K9ac (Abcam ab4441) elleni ellenanyagot 1:200-szoros hígításban, H3K14ac (Upstate 07-353) elleni ellenanyagot 1:200-szoros hígításban, H4K12ac (Abcam ab1761) elleni ellenanyagot 1:200-szoros hígításban, H4K8ac (Abcam ab1760) elleni ellenanyagot 1:100-szoros hígításban, dADA2b elleni ellenanyagot 1:100-szoros hígításban valamint anti-RNAPII (1BP-7G5) elleni ellenanyagot 1:500-szoros hígításban használtunk. Ezt követően a mintákat 3-szor 10 percen keresztül mostuk 1X PBS oldatban, majd hozzáadtuk a másodlagos ellenanyagot, amit 1\% BSA PBST oldatban hígítottunk. Másodlagos ellenanyagként fluoreszcens festékkel konjugált IgG elleni Alexa Fluor 488at, Alexa Fluor 555-t, illetve DYlight 549-t használtunk 1:500, valamint 1:800-as hígításokban. A mintákat 2 órán keresztül inkubáltuk másodlagos ellenanyagokat tartalmazó 2\% BSA-PBST oldatban, majd 3-szor 10 percig 1X PBST-ben mostuk. Az utolsó előtti mosásnál az $1 \mu \mathrm{g} / \mathrm{ml}$ DAPI-PBST oldatban a mintát 5 percig sötétben inkubáltuk. A minták lefedésénél Prolong Gold-ot használtunk. Az így elkészített mintákat Olympus BX51 mikroszkóppal vizsgáltuk.

\subsection{Immunprecipitáció}

$w^{1118}$ és dTaf10 ${ }^{d 25}$ L3-as lárvákat gyüjtöttünk, majd homogenizáltuk proteáz inhibítor koktélt (cOmplete Protease Inhibitor Cocktail Tablets in EASYpacks Roche) tartalmazó nem denaturáló lízis pufferben (1\% Triton X-100, $50 \mathrm{mM}$ Tris-HCl pH 8 and $150 \mathrm{mM} \mathrm{NaCl}$ ). Ezt követően a mintákat centrifugáltuk (400 g, 5 perc, $4{ }^{\circ} \mathrm{C}$ ). A fehérje 
koncentrációkat Bradford reagenssel határoztuk meg. Az így elkészített mintát 2 órán keresztül $4{ }^{\circ} \mathrm{C}$-on egyesszálú DNS-el blokkolt Protein A-Sepharose gyönggyel (Sigma Aldrich) inkubáltuk. Ezt követően a mintákat $4{ }^{\circ} \mathrm{C}$-on egy éjszakán keresztül inkubáltuk dTAF5 elleni ellenanyaggal. Az ellenanyag nélküli kontrollhoz is azonos mennyiségü fehérje mintát adtunk (300 $\mu \mathrm{g})$, majd ugyanúgy kezeltük, mint az immunprecipitált fehérje mintát. Ezután a gyöngyökhöz kötött TAF5 komplexeket centrifugálással gyüjtöttük össze, majd 4-szer mostuk nem denaturáló pufferrel. Végül az immunprecipitált mintákat 2X SDS mintafelvivő pufferben eluáltuk a gyöngyökről, majd 2000 g-n $4{ }^{\circ} \mathrm{C}$-on centrifugáltuk.

\subsection{RNS preparálás cDNS szintézis}

L3-as stádiumú lárvákat Trizol reagensben (Invitrogen) homogeniztáltunk. Egy L3as lárvához $5 \mu$ l-nyi Trizol reagenst adtunk. Ezt követően 5 percig $25^{\circ} \mathrm{C}$-on inkubáltuk a mintát. A mintához kloroformot adtunk (1 ml Trizolhoz $200 \mu 1$ kloroform), majd vortex segítségével összekevertük. Ezután $25^{\circ} \mathrm{C}$-on inkubáltuk 3 percen keresztül, ezt követően centrifugáltuk (12000 g, 15 perc, $4{ }^{\circ} \mathrm{C}$-on). A felső fázist egy új eppendorf csőbe helyeztük, majd izopropanolt ( $1 \mathrm{ml}$ trizolhoz $500 \mu$ izopropanol) adtunk a mintához és $25{ }^{\circ} \mathrm{C}$-on inkubáltuk 5 percig. Ezután 12000 g-n 10 percig $4{ }^{\circ} \mathrm{C}$-on centrifugáltuk a mintát, majd az alkoholos fázis eltávolítása után a csapadékot $75 \%$-os etanollal mostuk. Óvatos kevergetés után ismét centrifugáltunk (7500 g $4{ }^{\circ} \mathrm{C}$ ), majd az etanolt tartalmazó felső fázist eltávolítottuk. A csapadékot szárítottuk és steril vízben visszaoldottuk. Az RNS koncentrációját NanoDrop (ND-1000 Spectrophotometer) segítségével állapítottuk meg. Ezt követően $1 \mu \mathrm{g}$-nyi RNS-ből cDNS-t állítottunk elő Applied Biosystems Reverse Transcription Reagents Kit segítségével a gyári protokollban megadott reakciókörülményeket alkalmazva.

\subsection{Kvantitatív real time PCR (QPCR)}

A Kvantitatív real-time PCR reakciókat ABI 7500 Real Time PCR készülékkel végeztük. A PCR reakció során keletkező termékek kvantitatív meghatározásához, ROX festéket tartalmazó SYBR Green PCR Master Mix (Applied Biosystems) reagenst használtunk. A reakciók során az alábbi körülményeket alkalmaztuk: $95{ }^{\circ} \mathrm{C} 10$ perc; $95^{\circ} \mathrm{C}$ 15 másodperc; $60{ }^{\circ} \mathrm{C} 1$ perc 45 cikluson keresztül. Kísérleteink során 2 egymástól függetlenül gyüjtött mintákon végeztük a méréseket $25 \mu$ l-es végtérfogatban. Az 
expressziós vizsgálatoknál 100-szorosan hígított cDNS mintákból készítettünk kalibrációs egyenest, majd abszolút kvantifikálással határoztuk meg a minták cDNS tartalmát.

A dTaf10, valamint a dTaf10b expressziójának meghatározásához az alábbi primereket használtuk:

Taf10 Fwd: 5' CTTGAAAACGGCTGGCTTCT 3'

Taf10 Rev: 5' CGCTGGAATGCTGGATGTTC 3'

Taf10b Fwd: 5' ATCGGGATAGGACCACACCA 3'

Taf10b Rev: 5' CGACTGAAAGCCTCCCATGT 3'

\subsection{RT PCR analízis}

A Haloween gének expressziójának vizsgálatához $w^{1118}$, illetve $d T a f 10^{d 25}$ mutáns L3 stádiumú lárvákat szinkronizáltunk az L3 lárva stádium legvégére, amikor az L3-as lárvák anterior spirákulumukat kitürik. Ezt követően 10 lárvából RNS-t izoláltunk Qiagen RNeasy Mini Kit segítségével a gyártó által mellékelt protokoll szerint. $1 \mu \mathrm{g}$ RNS-t használtunk a cDNS szintéziséhez, melynél cDNA Synthesis Kit-et (ABI) használtunk. A Halloween gének expressziójának vizsgálatához az alábbi primereket használtuk:

spookier Fwd: TATCTCTTGGGCACACTCGCTG

spookier Rev: GCCGAGCTAAATTTCTCCGCTT

phantom Forward: GGATTTCTTTCGGCGCGATGTG

phantom Reverse: TGCCTCAGTATCGAAAAGCCGT

disembodied Forward: TGCCCTCAATCCCTATCTGGTC

disembodied Reverse: ACAGGGTCTTCACACCCATCTC

shadow Forward: CCGCATTCAGCAGTCAGTGG

shadow Reverse: ACCTGCCGTGTACAAGGAGAG

shade Forward: CGGGCTACTCGCTTAATGCAG

shade Reverse: AGCAGCACCACCTCCATTTC

molting defective Forward: AGCAGCGATAATGCCGTCGACT

molting defective Reverse: ACACATTTCCGCCGGAACTTGG 
neverland Forward: GGAAGCGTTGCTGACGACTGTG

neverland Reverse: TAAAGCCGTCCACTTCCTGCGA

forrás: [88]

3.8. dAda2b ${ }^{d 842}, d A d a 2 a^{d 189}, d T a f 10^{d 25}$ és $w^{1118}$ Drosophila melanogaster törzsek transzkriptóm analízise DNS microarray-el

A $d T a f 10^{d 25}$, a $d A d a 2 b^{d 842}$ és a $d A d a 2 a^{d 189}$ és a $w^{1118}$ törzsek transzkriptom analízise párhuzamos körülmények között történt. A $d A d a 2 b^{d 842}, d A d a 2 a^{d 189}, d T a f 10^{d 25}$ és $w^{1118}$ törzsek transzkriptóm vizsgálatához az állatokat 4 óránként szinkronizáltuk a lárva stádium legvégén megjelenő anterior spirákulum kitürt állapotra. A mutáns és a kontroll $w^{1118}$ lárvák szinkronizálása ugyanazon a napon és ugyanabban a napszakban történt. Minden genotípusból három párhuzamos mintát gyüjtöttünk, egyenként mindegyik 10-10 db lárvát tartalmazott. A lárvákból Qiagen RNeasy kit segítségével RNS-t izoláltunk, követve a gyártó által javasolt protokollt. Ezt követően a microarray kísérleteket az IGBMC Christelle Thimbaud Affymetrix laborjában végezték el. A Drosophila lárvák DNS microarray analízise megtalálható a [89] forrásban. A microarray adatok elérhetőek a European Bioinformatics Institute honlapján (http://www.ebi.ac.uk/arrayexpress/) EMTAB-3842 and E-MEXP-2125 azonosítószám alatt.

\subsection{Ekdizon és koleszterin etetés}

$\mathrm{Az}$ ekdizon és a koleszterin etetéshez dTaf10 ${ }^{d 25}$ lárvákat L2, illetve L3-as lárvastádium közötti vedlésre szinkronizáltuk, majd a lárvákat tovább inkubáltuk 24 órán keresztül, hogy elérjék az L3-as lárvastádium közepét. Ezután a lárvákat áthelyeztük ekdizon, illetve koleszterin tartalmú táptalajra. Az ekdizont 0,5 mM koncentrációban, míg a koleszterint $14 \mathrm{mg} / \mathrm{g}$ koncentrációban alkalmaztuk. A lárvákat $25^{\circ} \mathrm{C}$-on tartottuk. 


\section{Eredmények}

\section{1. dTaf10/dTaf10b deléciók létrehozása}

Laborunkban korábban, - a P\{SUPor-P\}Taf10 ${ }^{K G 07031}$ inszerciós elemet hordozó transzgenikus Drosophila törzsek felhasználásával - a dTaflob és a dTaf10 géneket érintő deléciót hordozó null mutáns állatokat hoztak létre. A $d T a f 10^{\mathrm{d} 25}$ allélben a deléció mérete 900 bázispár hosszúságú, mely érinti a dTaf10 és a dTaf10b géneket, ugyanakkor a szomszédos gének (Aph-1, Colt) szakaszaira nem terjed ki (9. ábra). A dTAF10/dTAF10b fehérjéket nem tartalmazó mutáns Drosophila vonalat a továbbiakban dTaf10 125 -tel jelölöm. Fenotípus vizsgálatok során azt láttuk, hogy a dTAF10/TAF10b fehérjék hiánya késői L3, illetve báb letalitást okoz. A vizsgált $d T a f 10^{d 25}$ deléciót tartalmazó Drosophila lárvák 60\%-a abnormális bábot formál, 40\%-a pedig a késői L3 stádiumban pusztul el (10. ábra A, B).

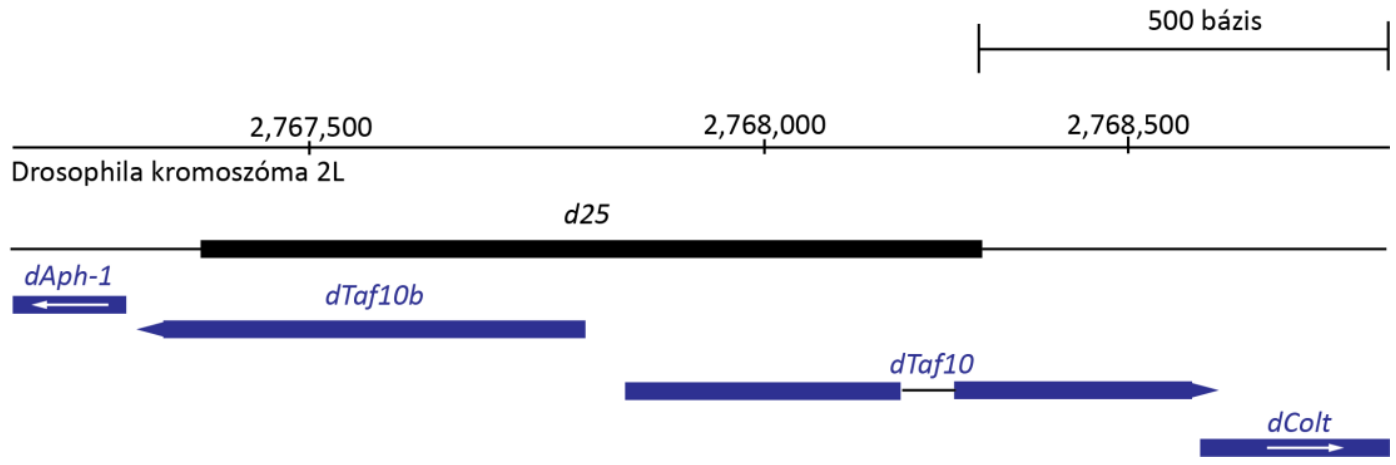

9. ábra:A $d T a f 10$, illetve a $d T a f 10 b$ gének környezete, d25 deléció elhelyezkedése. A d25-el jelzett fekete téglalap a dTaf10 és a dTaf10b-t érintő 900 bázispár hosszúságú deléció elhelyezkedését mutatja. A dTaf10 és a dTaf10b-vel jelzett kék nyilak a dTaf10/dTaf10b gének 5'3' irányultságát jelentik. A dTaf10 esetében az intronikus szakaszt a kék nyíl és a kék téglalap közötti fekete vonal jelzi. A $d A p h-1$ és a $d$ Colt felirattal jelzett kék téglalapok a $d T a f 10$ és a $d T a f 10 b$ szomszédságában jelenlévő gének részleteit ábrázolják. A fehér nyilak a gének 5'-3' irányultságát mutatják.
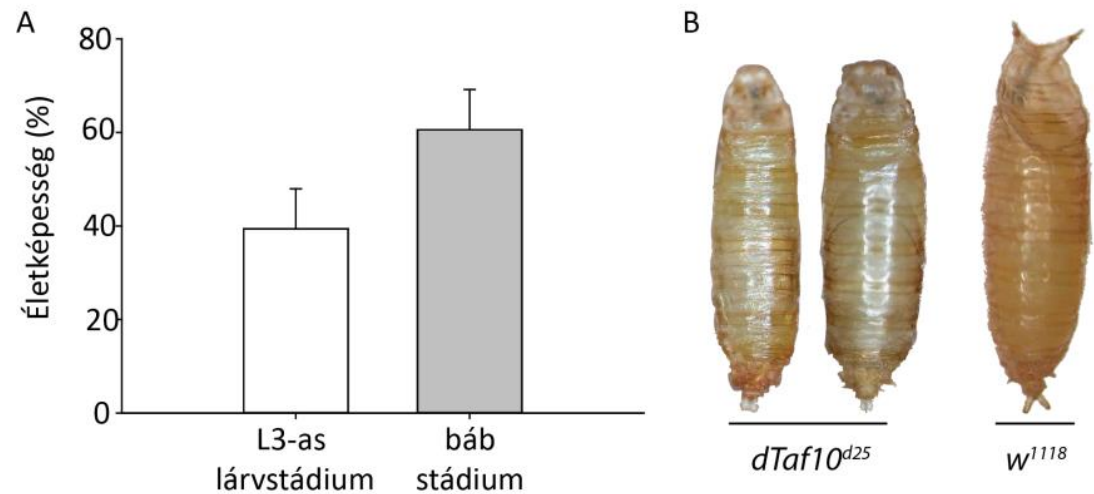

10. ábra: $\boldsymbol{d} \operatorname{Taf1}^{d 25}$ mutáns állatok fenotípus vizsgálata: A) A vizsgált állatok $40 \%$-a L3-as lárvastádiumban, 60\%-a báb stádiumban pusztul el. B) A $d T a f 10^{d 25}$ mutáns és $w^{1118}$ bábok fenotípusa. A mutáns bábokon az anterior spirákulum hiányzik. 


\subsection{Génexpresszió változások összehasonlítása a dTAF10/dTAF10b fehériéket nem tartalmazó és dSAGA hiszton acetiltranszferáz hiányos állatokban}

Mivel a dTAF10b a dSAGA komplex része, ezért a dTAF10/dTAF10b hiánya miatt kialakuló transzkripciós változások érinthetik a dSAGA által szabályozott génexpressziót is. A $d T_{a f 1} 0^{d 25}$ mutánsokban végbemenő génexpressziós változások vizsgálatához DNS microarray segítségével transzkriptom vizsgálatot végeztünk. Ahhoz, hogy megállapítsuk a dTAF10 fehérjék hiányában létrejövő génexpressziós változások milyen mértékben köthetők a dSAGA komplex által szabályozott transzkripciós változásokhoz, a dTaf10 $0^{d 25}$ mutáns Drosophila lárvák transzkripciós változásait összehasonlítottuk a dADA2b fehérjét nem tartalmazó mutáns Drosophilák (Ada2 $b^{d 842}$ ) microarray adataival. Az $A d a 2 b^{d 842}$ és a $d T A F 10^{d 25}$ mutáns lárvák microarray analízisét az L3-végén kialakuló előbáb stádiumú Drosophilákon végezték el párhuzamos körülmények között. Mivel a különböző fejlödési stádiumokban a génexpressziós mintázat nagymértékben eltérhet egymástól, az eredmények összevethetőségének érdekében a $d T A F 10^{d 25}$ és a $d A d a 2 b^{d 842}$ mutáns lárvákat is L3 végi előbáb stádiumra szinkronizáltuk. Az L3 végi előbáb stádiumban bekövetkező transzkripciós változások, nemcsak az adatok összevethetősége miatt voltak fontosak számunkra, hanem azért is, mert a $d T a f 10^{d 25}$ mutánsok pusztulása is ebben a stádiumban történik meg. Microarray kísérleteknél 14500 transzkriptumot tartalmazó Drosophila Genome2 Array-t használtak. A microarray adatok azt mutatták, hogy a dTAF10/dTAF10b fehérjék hiánya a vizsgált gének 34\%-ában okozott eltérő génexpressziós változást a kontrollhoz képest. A dTaf10 ${ }^{d 25}$ mutánsokban 2869 gén expressziója csökkent, valamint 2077 gén nagyobb mértékü expressziót mutatott a kontroll $w^{1118}$ Drosophilák transzkriptomjához viszonyítva (11. ábra). A $d A d a 2 b^{d 842}$ mutánsoknál bekövetkező transzkripciós változások a vizsgált gének mindössze 4\%-ában mutattak eltérő génexpressziót a kontrollhoz viszonyítva. Kísérleti eredményeink azt mutatják, hogy a dTAF10/dTAF10b hiánya a kontrollhoz képest több gén expresszióját érinti, mint a dAda2b hiánya. Ezért feltételeztük, hogy a dTAF10/dTAF10b fehérjék hiánya a dSAGA komplex mellett a dTFIID komplex által szabályozott génexpressziót is befolyásolhatja. A microarray adatok további vizsgálatánál azt láttuk, hogy a dADA2b hiányában a kontrollhoz képest eltérő expressziót mutató gének száma 543, melynek 44\%-a (253 gén) átfed a $d \operatorname{Tafl}^{d 25}$ mutánsokban tapasztalt, kontrollhoz képest eltérő expressziót mutató gének számával (11. ábra). Drosophilában valószínüleg a dTAF10b a dSAGA, a dTAF10 a dTFIID komplex része, ezért lehetséges, hogy a $d T a f 10^{d 25}$ mutánsokban kialakuló dSAGA specifikus génexpressziós változásokat a dTAF10b fehérje hiánya okozhatja. 

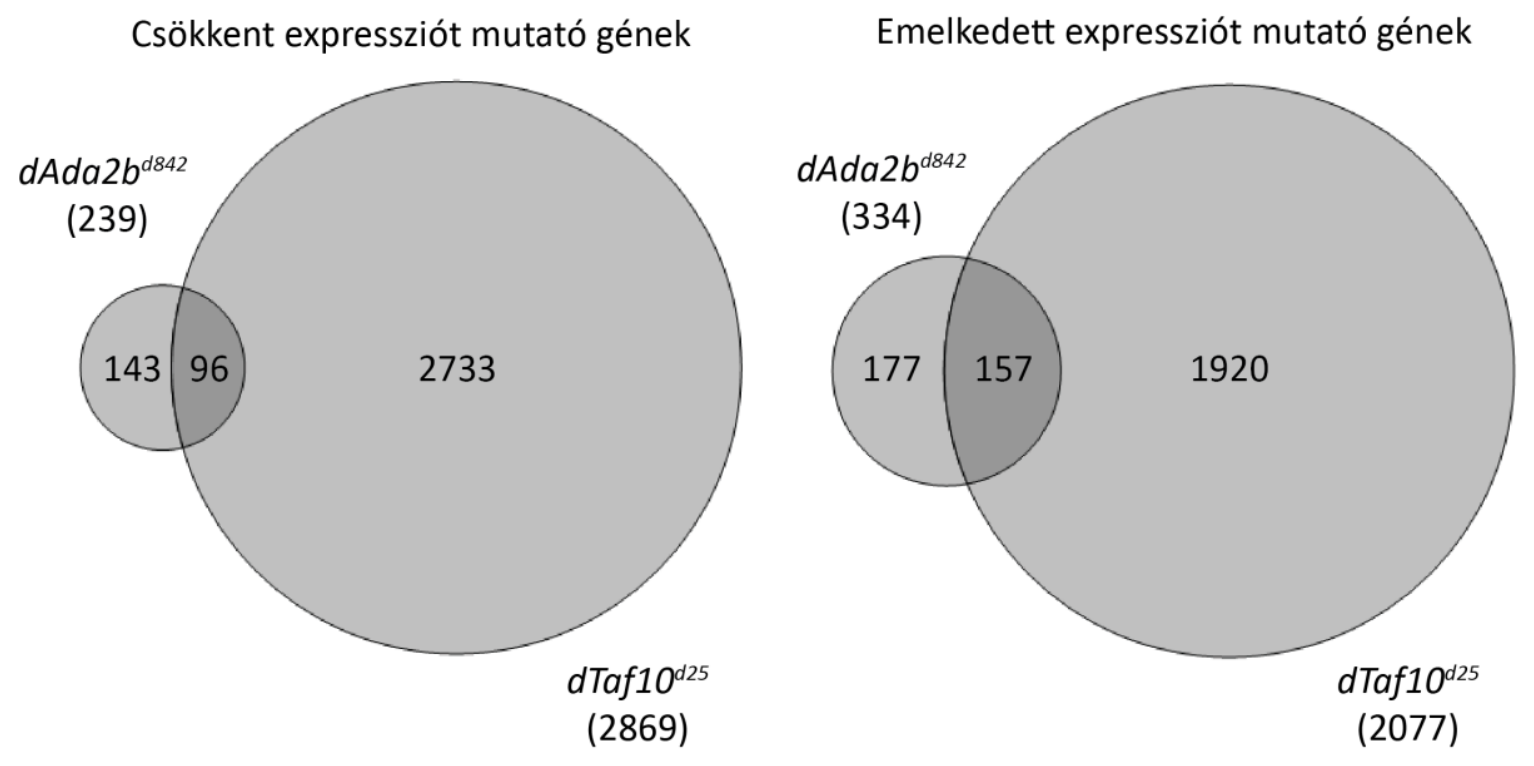

11. ábra: $d T a f 10^{d 25}$ és $d A d a 2 b^{d 842}$ mutánsokban kialakuló transzkripciós változások egymáshoz viszonyítva. A Venn diagrammok a $d T a f 10^{d 25}$ mutánsban és az $d A d a 2 b^{d 842}$ mutánsban kialakuló kontrollhoz képest eltérően expresszálódó gének száma közötti átfedéseket ábrázolják.

\section{3. dTAF10/dTAF10b hiányának hatása a dSAGA specifikus acetilációra}

Feltételezhető, hogy a dTAF10/dTAF10b fehérjék hiányában a dSAGA komplex stabilitása csökken, mely befolyásolhatja a dSAGA HAT aktivitását. Ennek a feltételezésnek az igazolására immunfestéssel vizsgáltuk, hogy a dTAF10/dTAF10b fehérjék hiányában hogyan változik a dSAGA specifikus H3K9 és H3K14 acetiláció a dTaf10 ${ }^{d 25}$ L3-as lárvák politén kromoszómáin. Azt tapasztaltuk, hogy a dTaf10 125 mutánsokban a dSAGA specifikus H3K14 acetiláció szintje csökken, az acetilált H3K9 mennyisége viszont változatlan marad a kontrollhoz képest (12. A ábra). Ezt követően Western blottal is analizáltuk, hogy a dTAF10/dTAF10b fehérjéket nem tartalmazó lárvákban hogyan változik a H3K14 acetiláció szintje a kontrollhoz viszonyítva. Kísérleteinkben azt láttuk, hogy késői L3-as lárvastádiumban a dTAF10 fehérjék valamint a dADA2b fehérjék hiányában kevesebb a 14-es lizinen acetilált H3 hisztonok mennyisége a kontrollhoz képest (12. B ábra). Eredményeinkből arra következtettünk, hogy a dTAF10b a dSAGA komplex alegységeként képes befolyásolni a dSAGA specifikus H3K14 acetilációt. 
A

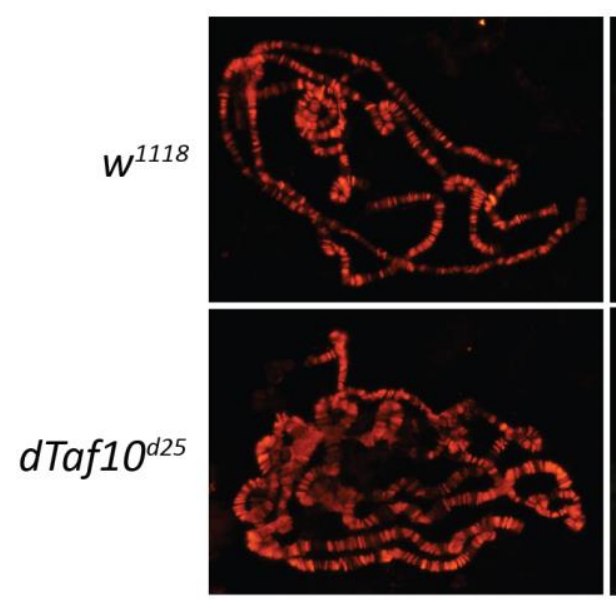

H3K14ac

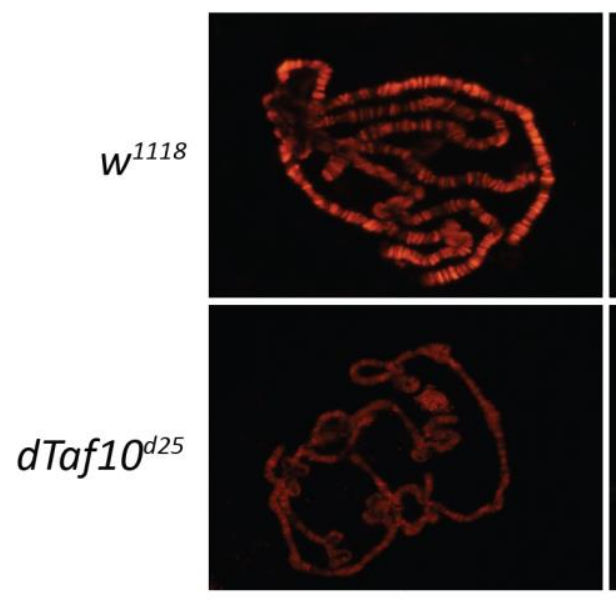

RNSPII

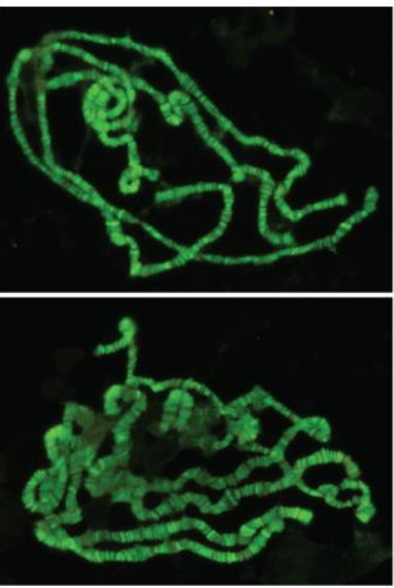

RNSPII
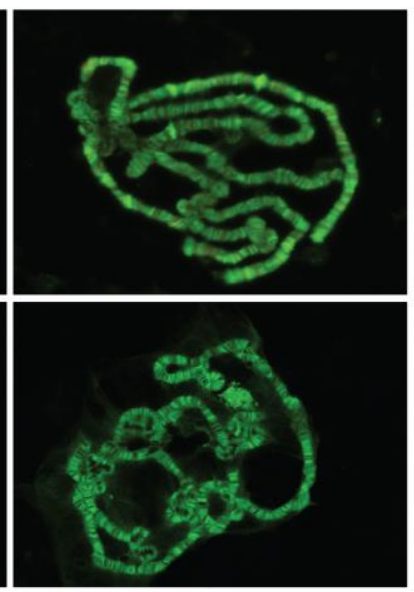

DAPI

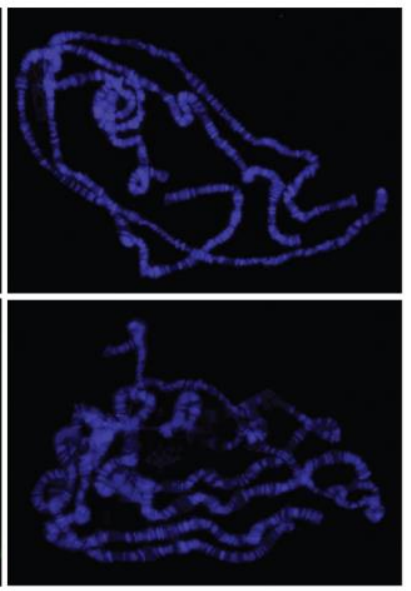

DAPI

B

H3K14ac

H3

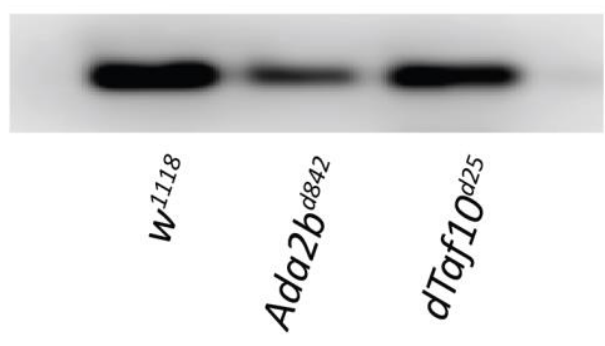

12. ábra: dSAGA specifikus hiszton acetiláció vizsgálata $d T a f 10^{d 25}$ mutánsban. A) A dTaf1 $10^{d 25}$, valamint a $w^{1118}$ L3-as lárvák nyálmirigy politén kromoszómáinak immunfestése. Acetilált H3K14, illetve acetilált H3K9 elleni ellenanyaggal vizsgáltuk a SAGA specifikus acetilációt a dTaf1 $10^{d 25}$, valamint a $w^{1118}$ L3-as lárvák nyálmirigy politén kromoszómáin (piros). RNS polimeráz II elleni ellenanyaggal vizsgáltuk az RNS polimeráz lokalizációját a dTaflo $0^{d 25}$, valamint a $w^{1118} \mathrm{~L} 3$-as lárvák nyálmirigy politén kromoszómáin (zöld). A kromoszómák kontrasztfestéséhez DAPI fluoreszcens festéket használtunk (kék). B) A $w^{1118}$, a dAda2 $b^{d 842}$ és a dTaf1 $10^{d 25}$ L3-as lárvákból származó fehérjemintákon végzett Western blot kísérlet acetilált H3K14 elleni ellenanyaggal. 
Mivel a dTaf10 $0^{d 25}$ mutánsokban csökken a dADA2b specifikus H3K14 acetiláció szintje, és a dTAF10/dTAF10b fehérjék hiánya befolyásolhatja a dSAGA komplex alegységeinek stabilitását is, megvizsgáltuk, hogy a dTAF10 fehérjék hiányában megváltozik-e a dADA2b lokalizációja a politén kromoszómákon. Azt találtuk, hogy a dADA2b lokalizációja a dTaf10 $0^{d 25}$ mutánsokban a kontrollhoz képest nem változik (13. A, B ábra). Kísérleteinkből arra következtettünk, hogy a $d T A F 10^{d 25}$ mutánsokban a H3K14 acetiláció szintjének csökkenése nem a dADA2b hiánya miatt alakul ki.

A
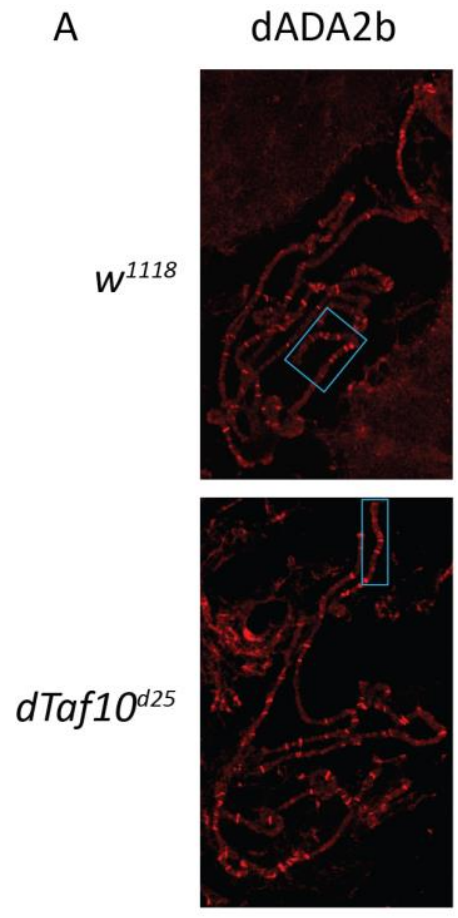

B
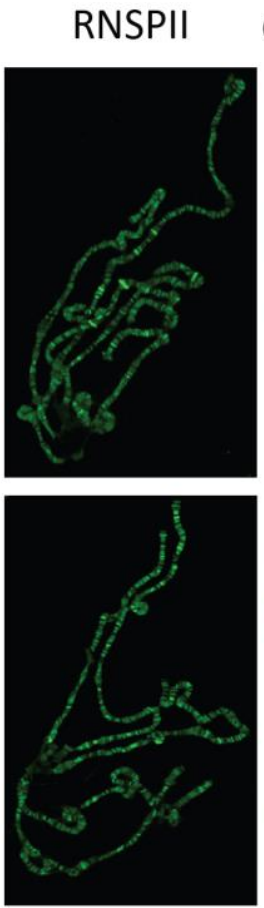
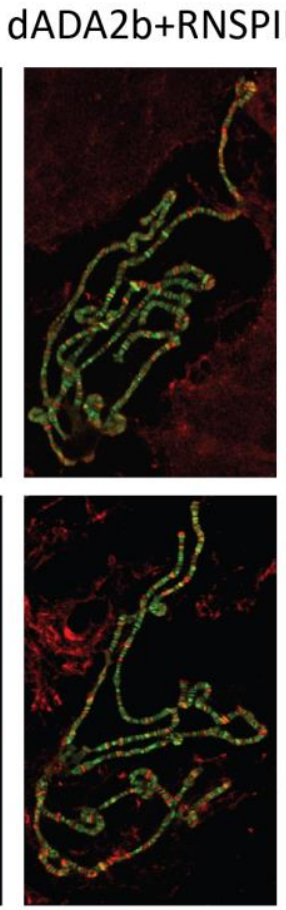

$\mathrm{dADA} 2 \mathrm{~b}$
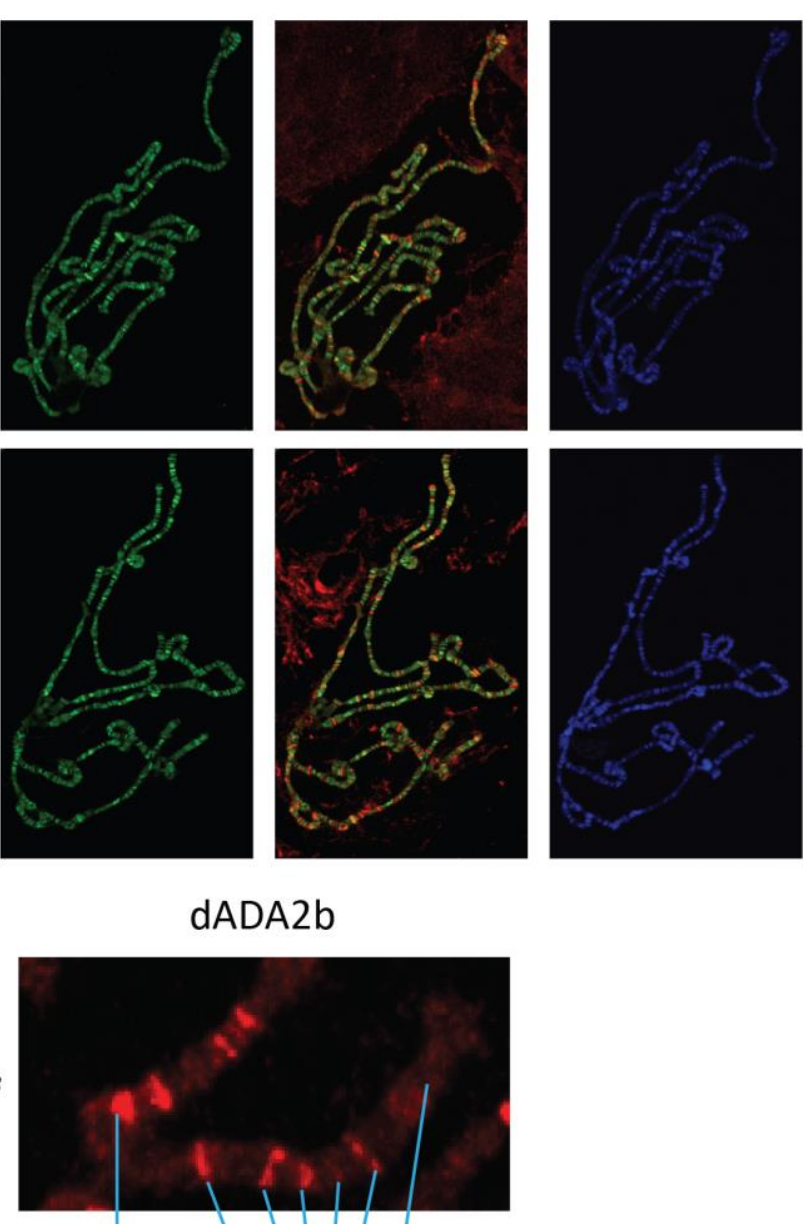

$d \operatorname{Taf} 10^{d 25}$

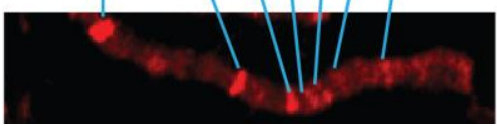

13. ábra: dADA2b lokalizációjának vizsgálata dTaf10 ${ }^{d 25}$ mutáns és $w^{1118}$ Drosophila törzsekben. A) $d T a f 10^{d 25}$ mutáns és $w^{1118}$ Drosophilák politén kromoszómáinak immunfestése dADA2b specifikus ellenanyaggal (piros). RNS polimeráz II elleni ellenanyaggal vizsgáltuk az RNS polimeráz lokalizációját a dTaf10 ${ }^{d 25}$, valamint a $w^{1118}$ L3-as lárvák nyálmirigy politén kromoszómáin (zöld). A dADA2b+RNSPII oszlopban a dADA2b (piros) és az RNS polimeráz II (zöld) immunfestésének egymásra vetített képe látható. A kromoszómák kontrasztfestéséhez DAPI fluoreszcens festéket használtunk (kék). B) Az ábra A részén kék keretben lévő kromoszóma részlet látható kinagyítva. A kromoszóma részleten a dADA2b lokalizációját láthatjuk a $d T a f 10^{d 25}$, illetve kontroll $w^{1118}$ Drosophila vonalban. 
4.4. dTAF10 és dTAF10b fehérjéket nem tartalmazó Drosophilák génexpressziós változásainak összehasonlítása a $d A d a 2 a^{d 189}$ (dATAC) mutánsokban tapasztalt transzkripciós változásokkal

Microarray adataink azt mutatták, hogy a dTAF10/dTAF10b hiányában kialakuló génexpresszió csak kis mértékben érinti a dSAGA specifikus génexpressziót. Feltételeztük, hogy a dTAF10/dTAF10b fehérjék a dSAGA komplex mellett más komplexek által szabályozott génexpressziót is befolyásolhatják. Ezért megvizsgáltuk, hogy a dATAC specifikus génexpresszió milyen mértékben fed át a $d T A F 10^{d 25}$ mutánsok génexpressió változásaival. A dADA2a fehérjét nem tartalmazó Drosophila melanogaster vonalat $\left(d A d a 2 a^{d 189}\right)$ a $d A d a 2 b^{d 842}$-es és a $d T a f 10^{d 25}$ mutánsokhoz hasonlóan az L3 végi előbáb stádiumra szinkronizálták, majd DNS micorarray-el transzkriptom vizsgálatot végeztek. A $d T a f 10^{d 25}$, a $d A d a 2 b^{d 842}$ és a $d A d a 2 a^{d 189}$ és a $w^{1118}$ törzsek transzkriptom analízise párhuzamos körülmények között történt. A $d T a f 10^{d 25}$ és a $d A d a 2 a^{d 189}$ mutánsok microarray adatainak összehasonlításakor azonban sokkal nagyobb átfedést tapasztaltunk, mint a dSAGA $\left(d A d a 2 b^{d 842}\right)$ és a $d T a f 10^{d 25}$ mutánsok transzkriptómjainak összevetésekor (14. ábra).

Csökkent expressziót mutató gének

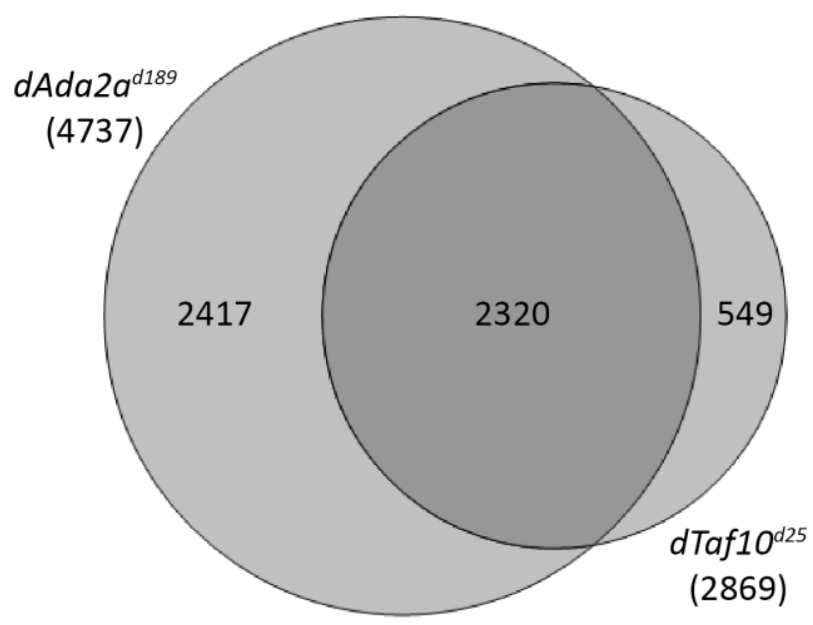

Emelkedett expressziót mutató gének

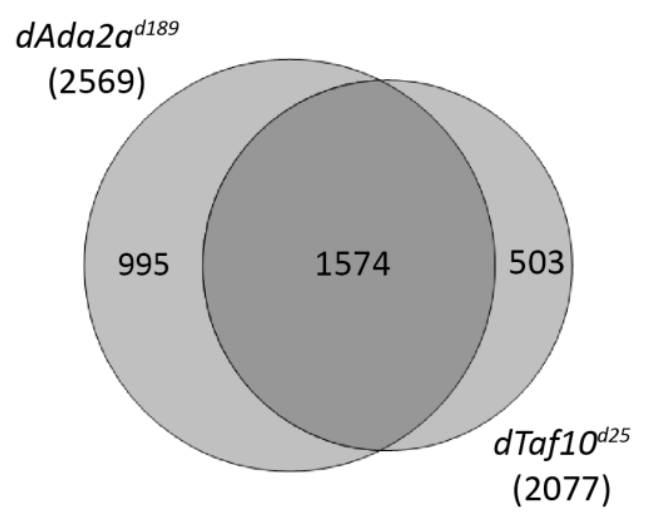

14. ábra: dTaf10 ${ }^{d 25}$ és dAda2a ${ }^{d 189}$ mutánsokban kialakuló transzkripciós változások egymáshoz viszonyítva. A Venn diagrammok a $d T a f 10^{d 25}$ mutánsban valamint az $d A d a 2 a^{d 189}$ mutánsban kialakuló, kontrollhoz képest eltéröen expresszálódó gének száma közötti átfedéseket ábrázolják.

Megvizsgáltuk, hogy a $d A d a 2 a^{d 189}$ és a $d T a f 10^{d 25}$ mutánsok esetében a kontrollhoz képest eltérő expressziót mutató gének milyen mértékben érintik az egyes génontológiai kategóriákat (15. ábra). Azt tapasztaltuk, hogy a $d A d a 2 a^{d 189}$ és a $d T a f 10^{d 25}$ mutánsokban az aktivált és a represszált gének is hasonló génontológiai kategóriákba tartoznak (15. ábra). 

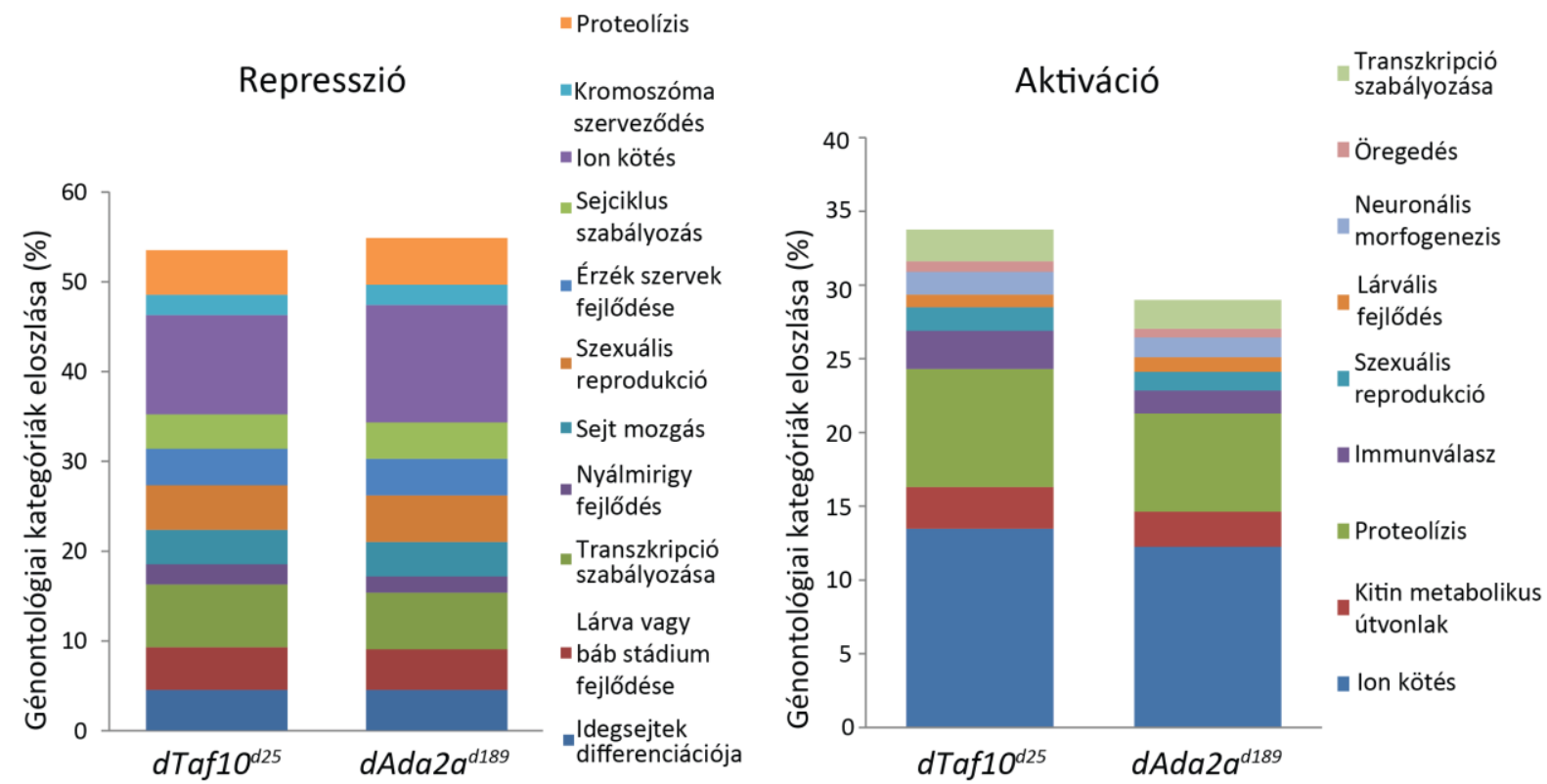

15. ábra: dTAF10 és dADA2a hiányában kialakuló expressziós változások génontológiai csoportosításának százalékos eloszlása.

Annak ellenére, hogy a dTAF10b fehérje a dSAGA komplex része, a hiányában bekövetkező transzkripció változások 78\%-a megegyezik a dAda2a $a^{d 189}$ (dATAC) mutánsokban tapasztalt génexpresszió változásokkal. A $d T A F 10^{d 25}$ és a dATAC mutánsokban a kontrollhoz képest eltérő expressziót mutató gének funkció szerinti csoportosításánál szintén nagyfokú hasonlóságot tapasztaltunk. Eredményeink alapján feltételeztük, hogy a dATAC komplex és a dTAF10 tartalmú komplexek között funkcionális kapcsolat alakulhat ki.

\section{5. dTAF10 és dTAF10b hiányának hatása a dATAC, illetve GCN5 specifikus acetilációra}

Mivel a $d T a f 10^{d 25}$ mutánsokban tapasztalt transzkriptom változások nagymértékben hasonlítanak az dATAC mutánsokban tapasztalt génexpressziós változásokra, feltételeztük, hogy a dTAF10 fehérjék hiánya hatással van a dATAC komplex HAT aktivitására. Ezért immunfestéssel analizáltuk, hogy a $d T_{a f 10^{d 25}}$ lárvák politén kromoszómáin hogyan változik a dATAC specifikus H4K12, illetve a GCN5 specifikus $\mathrm{H} 4 \mathrm{~K} 8$ acetiláció a kontroll állatok nyálmirigy kromoszómáihoz képest. Azt láttuk, hogy sem a 8-as lizinen acetilált H4 hisztonok mennyisége, sem a H4K12 acetiláció szintje nem változik a nyálmirigy óriáskromoszómáin a $d$ Taf1 ${ }^{d 25}$ mutánsokban a kontrollhoz viszonyítva (16. ábra). Eredményeink alapján feltételezhető, hogy a dTAF10/dTAF10b tartalmú komplexek nem befolyásolják a dATAC HAT aktivitását. 


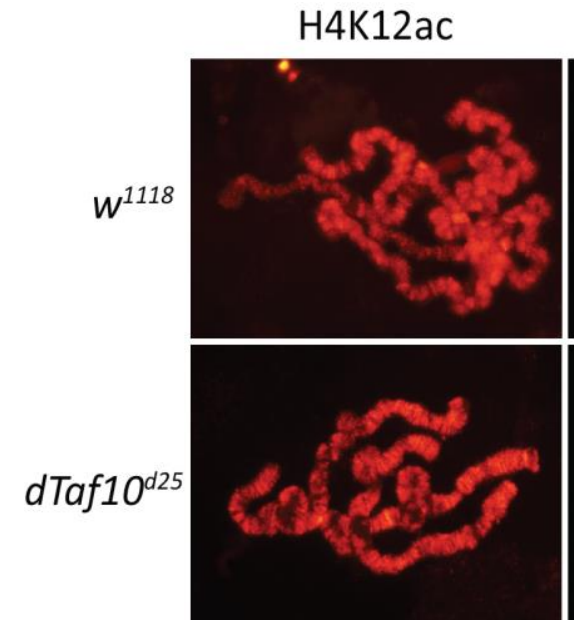

H4K8ac



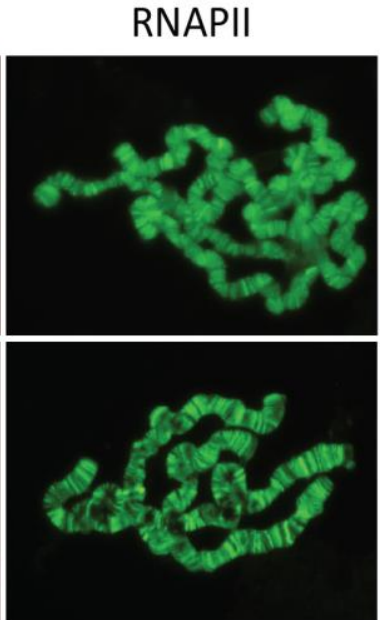

RNAPII


DAPI

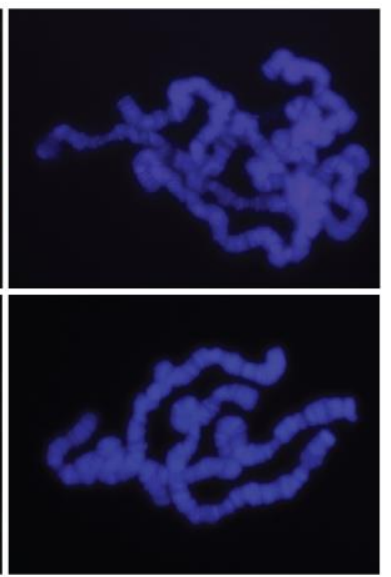

DAPI
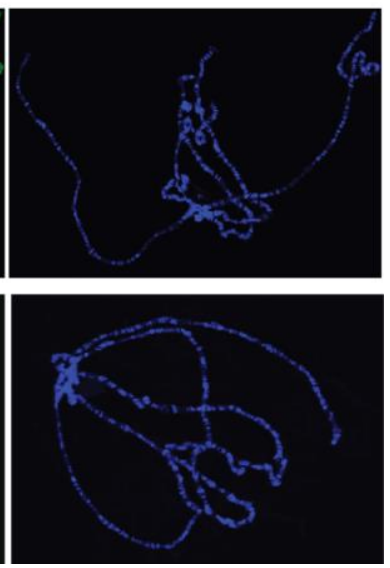

16. ábra: A H4K8 és H4K12 acetiláció vizsgálata dTaf10 ${ }^{d 25}$ mutánsban. A $d T a f 10^{d 25}$ és a $w^{1118}$ L3-as lárvák nyálmirigy politén kromoszómáinak immunfestése. Acetilált H4K12, illetve acetilált H4K8 elleni ellenanyaggal vizsgáltuk az ATAC és a GCN5 specifikus acetilációt a $d$ Taf10 ${ }^{d 25}$ valamint a $w^{1118}$ L3-as lárvák nyálmirigy politén kromoszómáin (piros). RNS polimeráz II elleni ellenanyaggal vizsgáltuk az RNS polimeráz lokalizációját

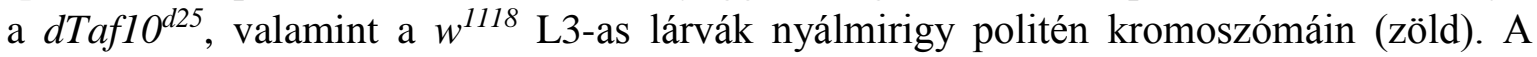
kromoszómák kontrasztfestéséhez DAPI fluoreszcens festéket használtunk (kék).

\subsection{A dTAF10 és a dTAF10b szerepe a dTFIID alegységek összeszerelödésében}

Korábbi tanulmányokban kimutatták, hogy a dTAF10 hiánya a dTFIID instabilitásához vezethet egér sejtekben [75]. Drosophila melanogaster esetében még nem tisztázott, hogy a dTAF10 fehérje hogyan befolyásolja a dTFIID összeszerelődését, stabilitását, illetve az sem világos, hogy a dTAF10 fehérjék hiányában összeszerelődik-e a dTFIID komplex. Első lépésben immunfestéssel megvizsgáltuk, hogy a $d T A F 10^{d 25}$ mutáns L3-as lárvák óriáskromoszómáin hogyan változik a dTFIID központi részében előforduló dTAF5 lokalizációja a kontrollhoz képest. Kísérleteinkben azt tapasztaltuk, hogy a dTAF5 fehérje mennyisége csökken a $d T a f 10^{d 25}$ mutánsok politén kromoszómáin (17. A ábra). Ebből arra következtettünk, hogy a dTAF10 fehérjék hiánya hatással van a dTAF5 
kötődésére. A dTAF5 fehérje szintjének csökkenése a politén kromoszómákon azért is bekövetkezhet, mert dTAF10/dTAF10b hiányában a TFIID destabilizálódik és a komplex tagjai degradálódnak. Ezért Western blottal megvizsgáltuk, hogy a dTaf10 ${ }^{d 25}$ mutánsban hogyan változik a dTAF5 fehérje szintje és azt tapasztaltuk, hogy a dTAF10 fehérjék hiánya nem befolyásolja a dTAF5 fehérje szintjét a $d$ Taf10 ${ }^{d 25}$ mutáns lárvákban (17. B ábra). A dTAF5 más dTAF fehérjékkel együtt alakítja ki a core dTFIID komplexet, ezért analizáltuk, hogy a dTaf10 ${ }^{d 25}$ mutánsban kialakulhat-e olyan dTAF5 tartalmú szubkomplex, mely hozzájárul a stabil dTFIID összeszerelődéséhez.

A
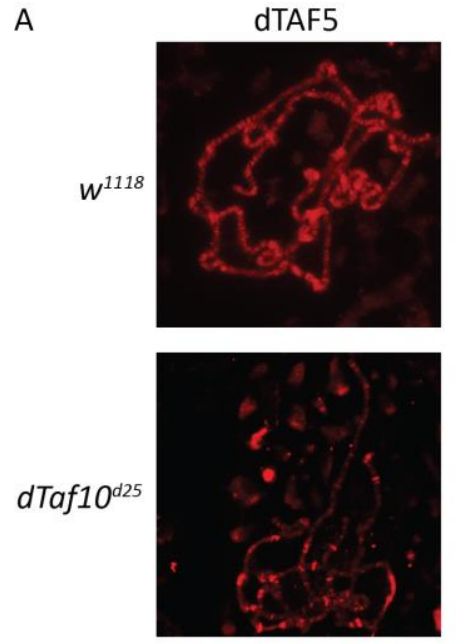

RNSPII
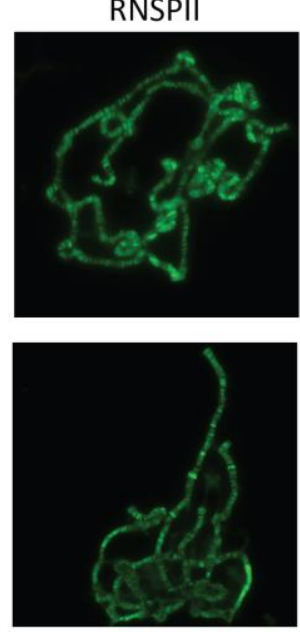

B
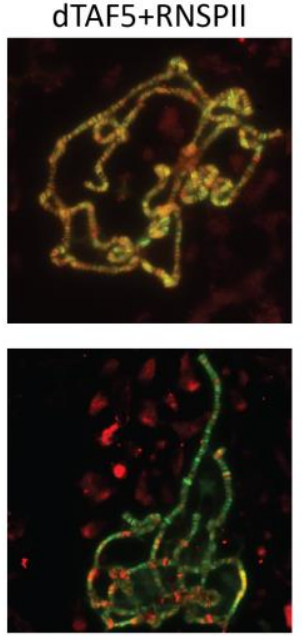
dTAF5

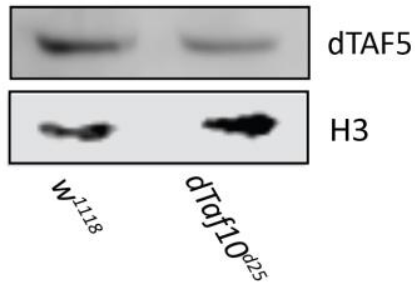

17. ábra A dTAF5 vizsgálata $\boldsymbol{d T a f 1 0 ^ { d 2 5 }}$ mutánsban. A) A $d T a f 10^{d 25}$, valamint a $w^{1118}$ L3-as lárvák nyálmirigy politén kromoszómáinak immunfestése. dTAF5 elleni ellenanyaggal és RNS polimeráz II elleni ellenanyaggal vizsgáltuk a dTAF5 (piros) és az RNS polimeráz II (zöld) lokalizációját a $d T a f 10^{d 25}$ és a $w^{1118}$ L3-as lárvák politén kromoszómáin. A dTAF5+RNSP II oszlopban a dTAF5 (piros) és az RNS polimeráz II (zöld) immunfestésének egymásra vetített képe látható. A kromoszómák kontrasztfestéséhez DAPI fluoreszcens festéket használtunk (kék). B) dTAF5 fehérje szintjének vizsgálata Western blottal dTAF10 ${ }^{d 25}$ L3-as, illetve $w^{1118}$ L3-as lárvákból készült fehérjemintákon.

Ko-immunprecipitációval vizsgáltuk, hogy a $d \operatorname{Taf} 10^{d 25}$ mutánsokban létrejön-e a holo dTFIID stabilitását nagymértékben befolyásoló dTAF4-dTAF5 szubkomplex. A dTaf10 ${ }^{d 25}$ mutáns és a kontrollként használt $w^{1118}$ Drosophilák feltárását követően antiTAF5 ellenanyaggal immunprecipitációt végeztünk. A TAF5 és TAF4 fehérjék közti kölcsönhatást a kontroll és a $d T a f 10^{d 25}$ mutáns állatokban is kimutattuk (18. A ábra). Ez alapján feltételezzük, hogy dTAF10/dTAF10b fehérjék hiánya nem befolyásolja a dTAF4- 
dTAF5 tartalmú dTFIID összeszerelődését. A core dTFIID felépítésében résztvevő dTAF4 és dTAF5 mellett Western blottal vizsgáltuk, hogy a dTAF6 fehérje szintje hogyan változik a $d T A F 10^{d 25}$ mutáns állatokban. Azt találtuk, hogy a dTAF6 fehérje szintje csökken a $d$ Taf10 ${ }^{d 25}$ mutánsokban a kontrollhoz képest (18. B ábra). Eredményeink azt sugallják, hogy a dTAF10 fehérjék hiánya befolyásolhatja a core dTFIID összeszerelödését, emellett a komplex más funkcionális moduljaiban található fehérjék mint például a dTAF6 - degradációjához vezethet. Továbbá immunfestéseknél azt láttuk, hogy a dTAF5 fehérje szintje csökken a dTaf $10^{d 25}$ mutánsok politén kromoszómáin, ezért feltételezhetjük, hogy a dTAF10/dTAF10b fehérjék befolyásolják a core dTFIID-t kialakító dTAF fehérjék kötődését a nyálmirigy óriáskromoszómáin.

A.

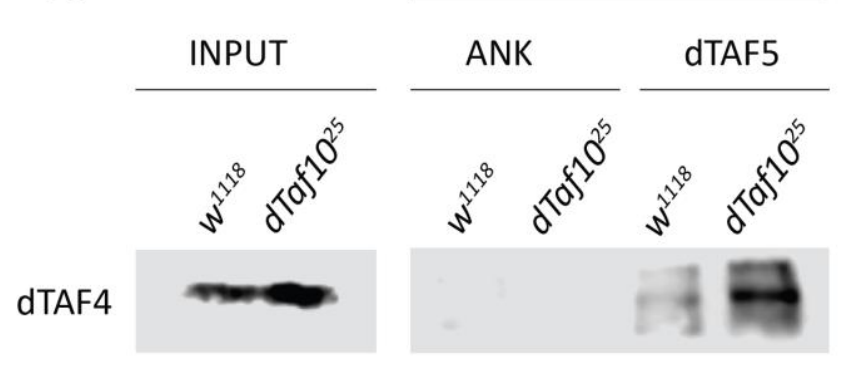

B.



18. ábra: A dTAF4-dTAF5 kölcsönhatás vizsgálata immunprecipitációval, valamint a dTAF6 fehérje szintjének vizsgálata $\boldsymbol{d T a f 1 0 ^ { d 2 5 }}$ mutánsban: A) dTAF5-re specifikus ellenanyaggal immunprecipitált mintából Western blot segítségével kimutattuk a dTAF4 fehérjét, dTAF4-re specifikus ellenanyaggal $w^{1118}$ és $d T a f 10^{d 25}$ Drosophila vonalakban. ANK=antitest nélküli kontroll B) dTAF6 vizsgálata $d$ Taf1 $10^{d 25}$ mutánsokban. Western blot kísérlet dTAF6-ra specifikus ellenanyaggal.

Ezt követően immunfestéssel analizáltuk, hogy a dTAF10/dTAF10b fehérjék hiánya hogyan befolyásolja a dTAF1 és a dTBP lokalizációját a politén kromoszómákon. Azt tapasztaltuk, hogy a dTAF1, valamint a dTBP fehérje szintje nem változik a kontrollhoz képest a $d T a f 10^{d 25}$ lárvák nyálmirigy óriáskromoszómáin (19. A, B ábra). A Western blot kísérleteinknél azonban azt láttuk, hogy a dTAF1 fehérje szintje nem változik, viszont a dTBP szintje csökken a $d T_{a f} 10^{d 25}$ mutánsokban a kontrollhoz képest (19. C ábra). Kísérleteinkből azt feltételezzük, hogy a dTAF10/dTAF10b fehérjék hiánya a dTBP és a dTAF1 tartalmú dTFIID DNS kötő aktivitását nem befolyásolja.

Az immunfestéseknél azt is megfigyelhetjük, hogy a dTAF5 a dTAF1-hez hasonlóan, az RNS polimeráz II-vel ko-lokalizációt mutat a kontroll állatok óriáskromoszómáin, viszont a dTAF10 és az RNS polimeráz ko-lokalizációját csak néhány helyen láthatjuk a politén kromoszómán (dTAF5: 17. A ábra 3. oszlop 1. sor. dTAF1: 19. A ábra 3. oszlop első sor, dTAF10: 20. ábra 3. oszlop 1. sor). Az eltérés abból adódhat, 
hogy a dTAF10 nem minden preiniciációs komplexben van jelen, illetve csak bizonyos gének transzkripciójához szükséges. Eredményeinkből az látszik, hogy a dTAF10/dTAF10b hiányában a dTFIID komplexet felépítő fehérjék közül a dTAF6, illetve a dTBP fehérje szintje csökken, emellett a dTAF5 fehérje szintje csökken a politén kromoszómákon. Ezáltal feltételezhetjük, hogy részleges dTFIID komplex szerelödik össze a dTaf $10^{d 25}$ mutánsban.

A

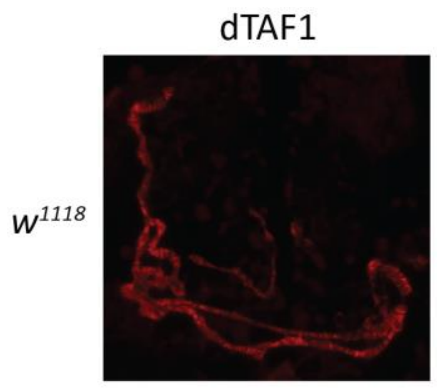

$d \operatorname{Taf} 10^{d 25}$

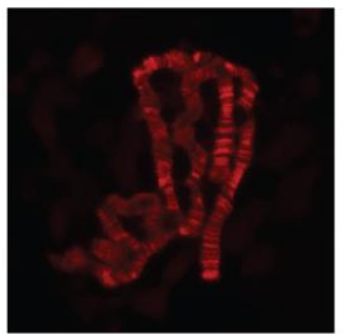

B
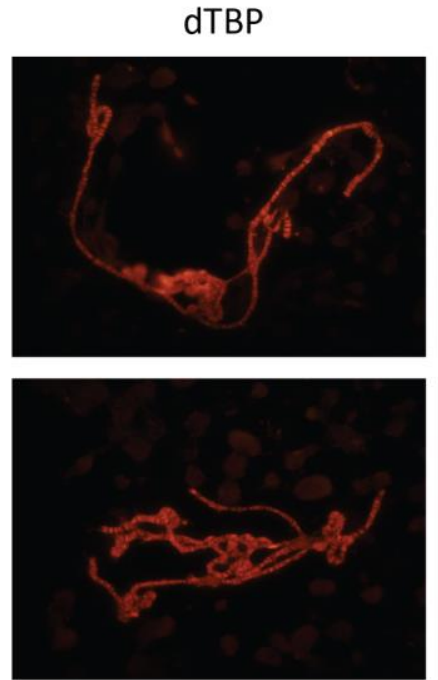

dTaf10 $0^{d 25}$
RNSPII
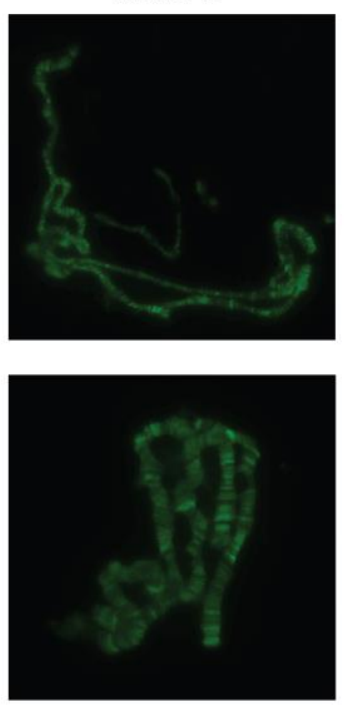

dTBP+DAPI


dTAF1+RNSPII
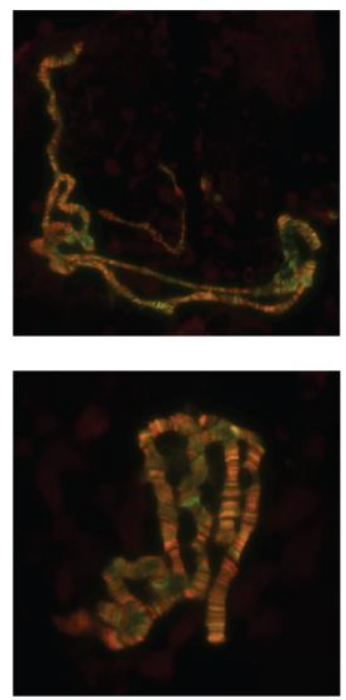

C

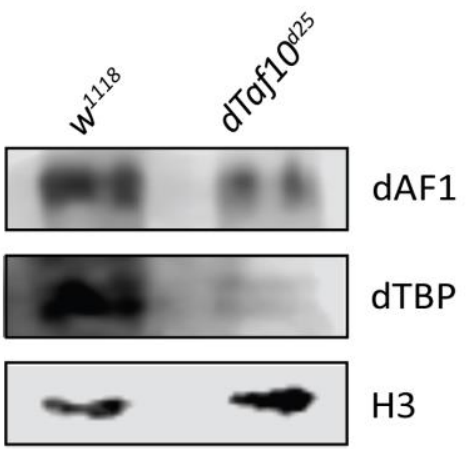

19. ábra: dTAF1 és dTBP vizsgálata dTaf10 ${ }^{d 25}$ mutánsban. A) A $d T a f 10^{d 25}$, valamint a $w^{1118}$ L3as lárvák nyálmirigy politén kromoszómáinak immunfestése. dTAF1 elleni ellenanyaggal és RNS polimeráz II elleni ellenanyaggal vizsgáltuk a dTAF1 (piros) és az RNS polimeráz II (zöld) lokalizációját a dTaf10 $0^{d 25}$ és a $w^{1118}$ L3-as lárvák politén kromoszómáin. A dTAF1+RNSP II oszlopban a dTAF1 (piros) és az RNS polimeráz II (zöld) immunfestésének egymásra vetített képe látható. A kromoszómák kontrasztfestéséhez DAPI fluoreszcens festéket használtunk (kék). B) A dTaf10 ${ }^{d 25}$, valamint a $w^{1118}$ L3-as lárvák nyálmirigy politén kromoszómáinak immunfestése. dTBP elleni ellenanyaggal vizsgáltuk a dTBP (piros) lokalizációját a $d T a f 10^{d 25}$ és a $w^{1118}$ L3-as lárvák politén kromoszómáin. dTAF1+DAPI oszlopban a dTBP (piros) immunfestése és a DAPI fluoreszcens festékkel festett kromoszóma egymásra vetített képe látható. C) H3, dTAF1 és dTBP Western blot analízise $w^{1118}$ - és $d T A F 10^{d 25}$-L3 lárvákból készült fehérjemintákon. 


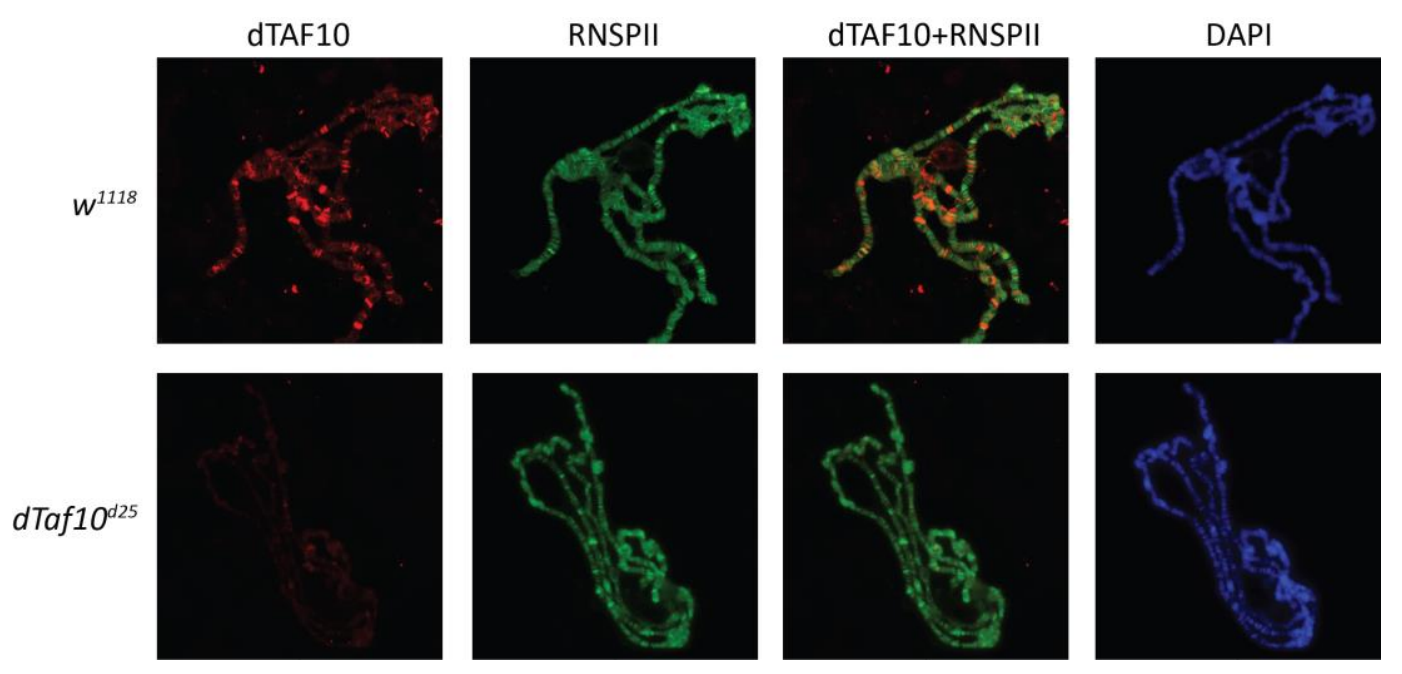

20. ábra: dTAF10 lokalizációjának vizsgálata $d T a f 10^{d 25}$ és $w^{1118}$ L3-as lárvák nyálmirigy óriáskromoszómáin. A $d T a f 10^{d 25}$ és a $w^{1118} \mathrm{~L} 3$-as lárvák nyálmirigy politén kromoszómáinak immunfestése. dTAF10 elleni ellenanyaggal vizsgáltuk a dTAF10 lokalizációját dTaf10 ${ }^{d 25}$, valamint a $w^{1118}$ L3-as lárvák nyálmirigy politén kromoszómáin (piros). RNS polimeráz II elleni ellenanyaggal vizsgáltuk az RNS polimeráz lokalizációját a $d T a f 10^{d 25}$, valamint a $w^{1118}$ L3-as lárvák nyálmirigy politén kromoszómáin (zöld). A dTAF10+RNSPII oszlopban a dTAF10 (piros) és az RNS polimeráz II (zöld) immunfestésének egymásra vetített képei láthatóak. A kromoszómák kontrasztfestéséhez DAPI fluoreszcens festéket használtunk (kék).

A dTFIID fontos szerepet játszik a preiniciációs komplex kialakulásában, azonban az RNS polimeráz II függő transzkripció dTFIID nélkül is megvalósulhat [90]. Az RNS polimeráz II jelenléte $d T A F 10^{d 25}$ mutáns lárvák óriáskromoszómáin azt jelzi, hogy dTAF10/dTAF10b fehérjék hiányában funkcionális dTFIID nélküli preiniciációs komplex alakulhat ki.

\subsection{A dTAF10 és dTAF10b hiányában kialakuló fenotípusok vizsgálata}

Microarray kísérletek alapján megállapítottuk, hogy a dTAF10/dTAF10b hiánya nagymértékű transzkripciós változásokat indukál, ezért megvizsgáltuk, hogy a dTAF10 fehérjék hiánya hogyan befolyásolja az állatok egyedfejlődését. A dTAF10/dTAF10b fehérjék hiánya késői L3 és báb letalitást okoz (10. ábra A, B). Ez alapján feltételeztük, hogy a $d T a f 10^{d 25}$ Drosophila lárvák esetében az L3 végi, illetve előbáb stádiumban bekövetkező letális fenotípus az ekdizon hormon hiánya miatt következik be. Ezért a dTaf10 ${ }^{d 25}$ mutáns lárvákat L2-L3 közötti vedlésre szinkronizáltuk, majd a 36 órás L3-as lárvákat 20-hidroxi-ekdizonnal kiegészített standard táptalajon neveltük. Kontrollként szintén L2-L3 közötti vedlésre szinkronizált $d T a f 10^{d 25}$ lárvákat használtunk, melyeket az L3-as lárvastádium kezdetét követően 36 óra elteltével normál táptalajra helyeztünk. Azt tapasztaltuk, hogy a 20-hidroxi-ekdizonnal kiegészített standard táptalajon nevelt $d T a f 10^{d 25}$ lárvák $88 \%$-a érte el az előbáb stádiumot, míg a normál táptalajon nevelt állatok mindössze 
54\%-a jutott el az elöbáb stádiumig (21. A ábra). Kísérletünk eredménye arra utal, hogy a dTaf10 ${ }^{d 25}$ mutánsoknál ekdizon hiányos állapot alakul ki az L3-as lárvastádium végén. Az ekdizon szintézis hibáját okozhatja az, hogy nem áll rendelkezésre elegendő szteránvázas vegyület, melyek az ekdizon metabolikus prekurzorai. Amikor azonban az L2-L3 közötti vedlésre szinkronizált $d T a f 10^{d 25}$ mutáns lárvákat koleszterinnel kiegészített standard táptalajon, illetve normál táptalajon neveltük, szignifikáns eltérést nem tapasztaltunk a standard és a koleszetrinnel kiegészített táptalajon nevelt állatok bábozódása között. A koleszterinnel kiegészített táptalajon nevelt állatok 68\%-a formált előbábot, míg a standard táptalajon nevelt lárvák 66\%-a érte el az előbáb stádiumot (21.B ábra). Eredményeink azt mutatják, hogy a 20-hidroxi-ekdizon hiánya nem abból adódik, hogy nem áll rendelkezésre elegendő metabolikus prekurzor az ekdizon szintéziséhez.

A

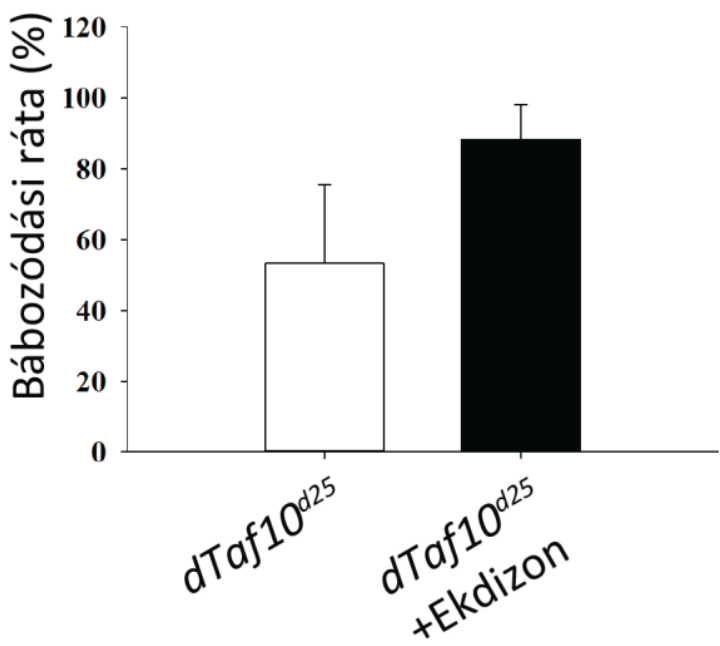

B Koleszterin

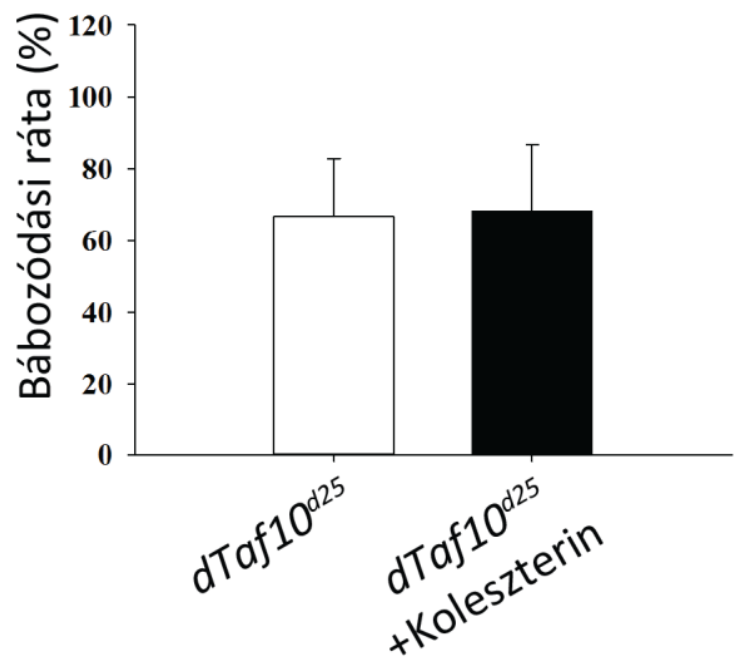

21. ábra: Ekdizonnal és koleszterinnel kiegészített normál táptalajon nevelt $d \operatorname{Taf} 10^{d 25} \mathrm{L3}$-as lárvák bábozódási rátája. A) L2-L3 közötti vedlésre szinkronizált $d T a f 10^{d 25}$ lárvákat normál, illetve 20-hidroxi-ekdizonnal kiegészített normál táptalajon neveltünk. A diagramm a normál (fehér oszlop), illetve a 20-hidroxi-ekdizonnal kiegészített táptalajon (fekete oszlop) nevelt $d T a f 10^{d 25}$ L3as lárvák bábozódási rátáját ábrázolja. B) L2-L3 közötti vedlésre szinkronizált $d T a f 10^{d 25} \mathrm{~L} 3$-as lárvákat koleszterinnel kiegészített normál táptalajon, illetve standard táptalajon tartottuk fent. A diagram a standard (fehér oszlop) és a koleszterinnel kiegészített táptalajon (fekete oszlopok) nevelt L3-as lárvák bábozódási rátáját mutatja.

Az ekdizon hiányos állapotot a gyürümirigy szöveti pusztulása is okozhatja. A dTaf10 ${ }^{d 25}$ mutánsok gyürümirigy morfológiája nem mutatott eltérést a kontrollhoz viszonyítva (22. ábra). Ebböl arra következtettünk, hogy a dTaf10 ${ }^{d 25}$ mutánsoknál tapasztalt ekdizon hiányos állapot nem a gyürümirigy szöveti degradációja miatt alakul ki. 


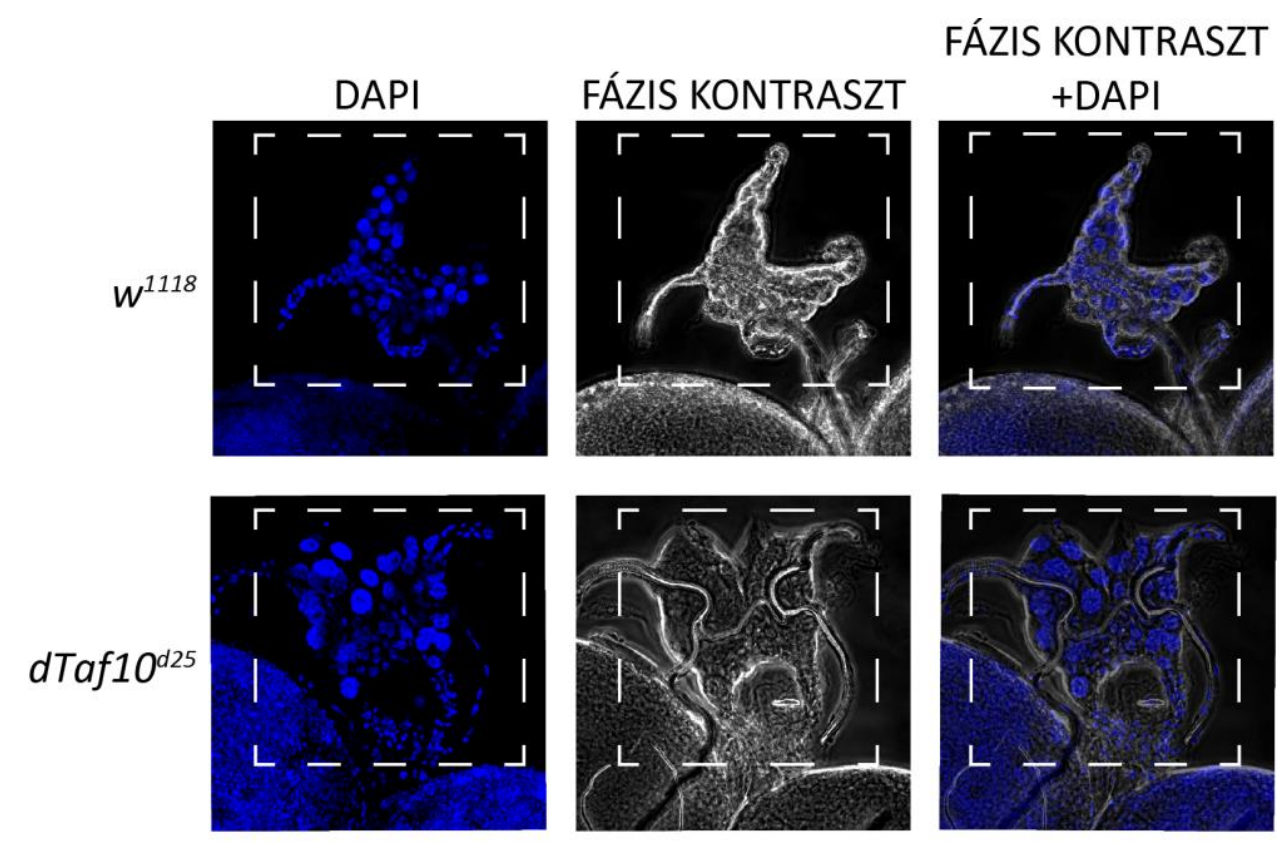

22. ábra: Gyűrümirigy morfológia vizsgálata $d T a f 10^{d 25}$ és $w^{1118}$ Drosophila vonalakban. $\mathrm{Az}$ ábrán a szaggatott téglalapok a gyürümirigyet jelölik.

\subsection{A dTaf5, dTaf8 és dTaf10 gének expressziójának csökkentése gyürümirigyben}

Kimutattuk, hogy a $d \operatorname{Tafl}^{d 25}$ mutánsok ekdizon hiányában tapasztalható L3, illetve bábletális fenotípusát nem a gyürümirigy degradációja okozza. dTaf $10^{d 25}$ mutáns lárvák L3 végi, illetve bábletális fenotípusa azért is bekövetkezhet, mert a dTAF10 fehérjék hiánya befolyásolja a gyürümirigyben végbemenő folyamatokat, melyek fontos szerepet játszanak az ekdizon szintézisben. Ezért transzgenikus dTaf10 RNS interferencia vonalak segítségével vizsgáltuk, hogy a dTaflo expressziójának csökkentése specifikusan a gyürümirigyben milyen fenotípust eredményez. Azt tapasztaltuk, hogy az állatok nagy része késői L3 stádiumban, kisebb részük korai báb stádiumban pusztul el. (23. ábra). Ezt követöen dTaf8-ra specifikus transzgenikus RNS interferencia Drosophila vonalak használatával specifikusan a gyürümirigyben csökkentettük a dTaf8 mRNS szintjét, mely során a lárvák nagy része - hasonlóan a dTaf10 siRNS interferencia vonalakhoz - késői L3 stádiumban pusztult el (23. ábra). A dTaf8, és a dTaf10 mellett a core dTFIID összeszerelődésében szerepet játszó dTaf5 mRNS szintjének csökkentése gyürümirigyben szintén késői L3-as letalitást okozott (23. ábra). 

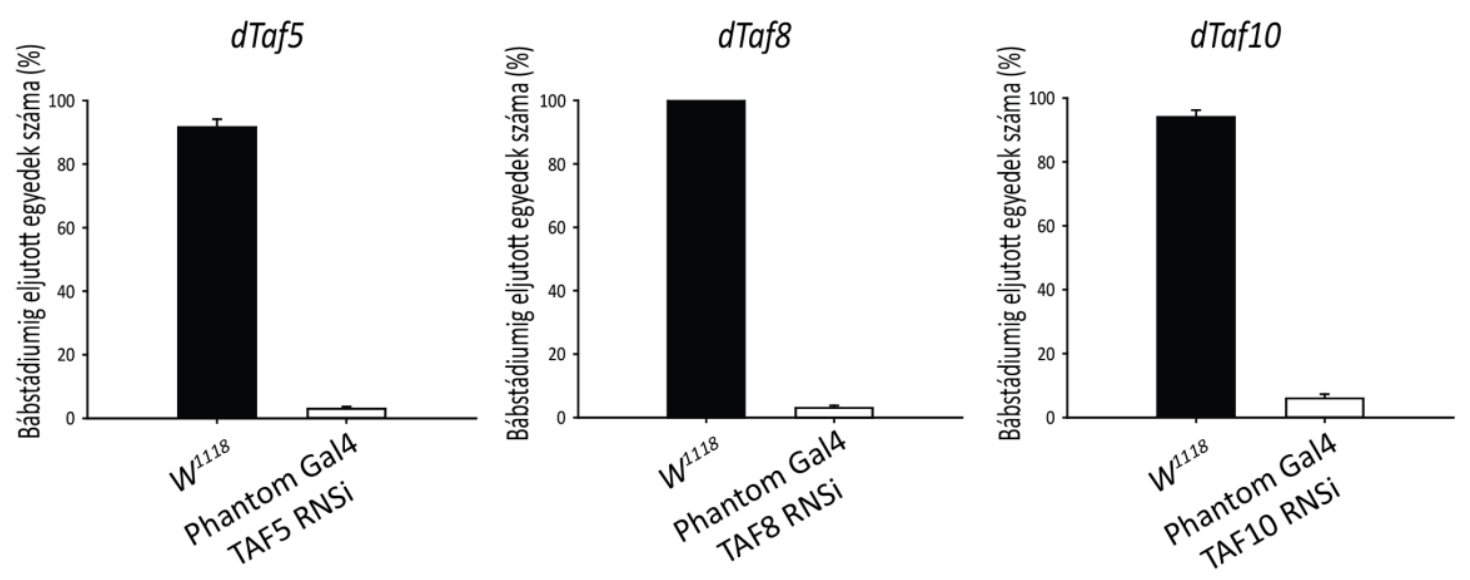

23. ábra: A dTaf5, dTaf8, és a dTaf10 expressziójának csökkentése a gyürümirigyben késői L3-korai báb letalitást okoz. phm-GAL4 driver törzs segítségével a gyürümirigyben csökkentettük a dTaf5, dTaf8, és a dTaf10 expresszióját. A dTaf5, dTaf8 és a dTaf10 expressziójának csökkentése során az állatok nagy része L3 stádiumban elpusztult.

Eredményeink arra utaltak, hogy dTaf5, dTaf8 és dTaf10 gének csendesítése következtében kialakuló letális fenotípust az ekdizon hiánya okozhatja, a dTaf10 $0^{d 25}$ mutánsokhoz hasonlóan. Feltételezésünk igazolására a lárvákat L2-L3 közötti vedlésre szinkronizáltuk, melyeknél a dTaf5, dTaf8 és dTaf10 gének expresszióját a gyürümirigyben csökkentettük. Ezt követően a 36h-s L3 lárvákat 20-hidroxi-ekdizon tartalmú standard táptalajon, illetve normál táptalajon tartottuk fent. Megfigyeltük, hogy az ekdizon menekítette a dTaf5, dTaf8 és a dTaf10 gének csendesítése következtében kialakuló L3 végi letális fenotípust prepupa, illetve P1-es báb stádiumig (24. ábra). Eredményeink azt sugallják, hogy a gyürümirigyben lezajló ekdizon szintézisben a dTAF5, a dTAF8 és a dTAF10 tartalmú dTFIID komplex vesz részt.
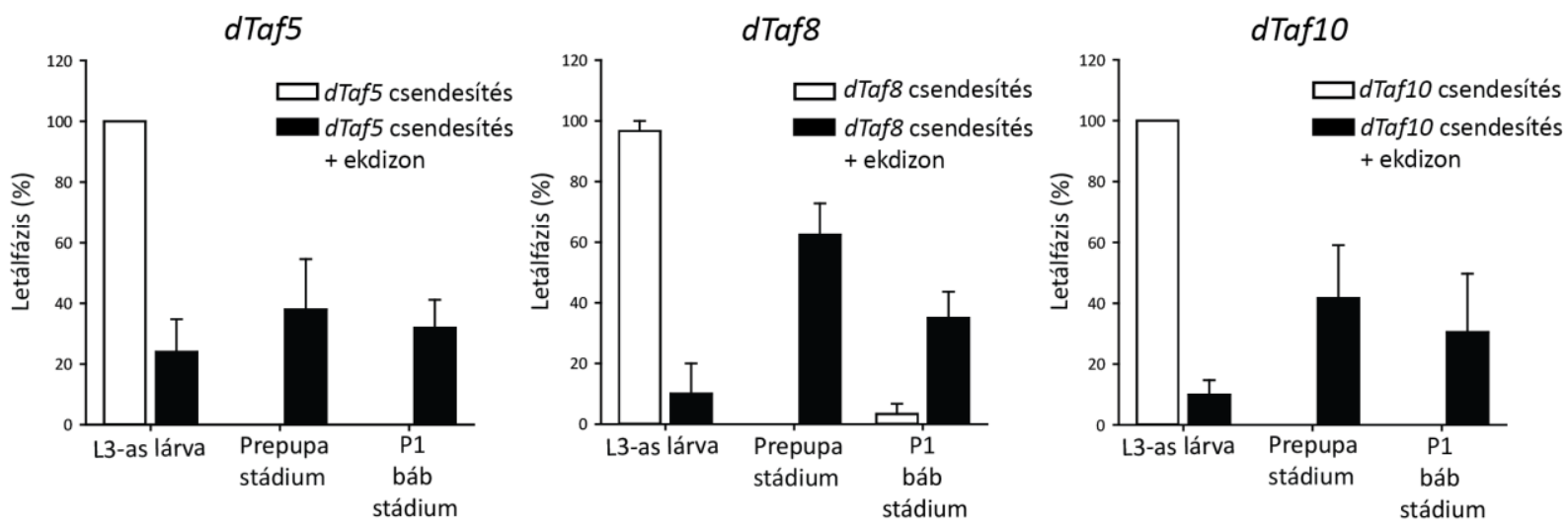

24. ábra: A $d T a f 5, d T a f 8$, és a $d T a f 10$ gének expressziójának csökkentése a gyürümirigyben késői L3 letalitást okoz, mely ekdizonnal menekíthető. Gyürümirigyben csökkentettük a dTaf5, dTaf8 és a dTaf10 expresszióját. Ezt követően 36h-s L3-as lárvákat ekdizonnal kiegészített táptalajon, illetve normál táptalajon tartottuk fent. Az ekdizon menekítette az L3 végi letalitást (fekete oszlopok), míg a normál táptalajon nevelt kontroll állatok nem érték el a báb stádiumot (fehér oszlopok). 


\subsection{Az ekdizon bioszintézisben résztvevő Halloween gének vizsgálata dTaf10 125 mutánsokban}

Kutatócsoportunk korábban kimutatta, hogy a $d A d a 2 a^{d 189}$ (dATAC) mutánsokban az ekdizon szintézisben résztvevő Halloween gének expressziója nagyrészt csökken és a dATAC mutánsok a $d T a f 10^{d 25}$ mutánsokhoz hasonlóan L3 végi, illetve báb stádiumban pusztulnak el [91]. Microarray kísérletek alapján megállapítottuk, hogy a dTAF10/dTAF10b függő transzkripciós változások nagymértékben hasonlítanak az ADA2a hiányában bekövetkező transzkripciós változásokhoz. További kísérleteinkben kimutattuk, hogy $d \operatorname{Taf} 0^{d 25}$ mutáns fenotípus nem a gyürümirigy degradációja miatt alakul ki. A letális fenotípus oka nem is a koleszterin hiánya a táptalajban. Megfigyeltük, hogy a dTaf10 mRNS szint csökkentése a gyürümirígyben is L3 végi letalitást eredményez. Ezek az eredmények arra utaltak tehát, hogy a dTAF10 és a dTAF10b fehérjék befolyásolhatják a gyürümirgyben végbemenő ekdizon szintézist. Ennek a feltételezésnek az alátámasztására megvizsgáltuk, hogy dTAF10 illetve dTAF10b hiányában hogyan változik a gyürümirigyben expresszálódó Halloween gének expressziója. Azt tapasztaltuk, hogy a gyürümirigyben expresszálódó Halloween gének (shadow, phantom, spookier, spook, disembodied) mRNS szintje csökken, míg a perifériás szövetben expresszálódó shade mRNS szintje nő dTAF10/dTAF10b hiányában (25. A ábra). A microarray adatok ellenörzéseképpen RT-PCR módszerrel is megvizsgáltuk, hogyan változik a Halloween gének expressziója a $d T a f 10^{d 25}$ mutánsokban. Azt láttuk, hogy a shade és a disembodied kivételével a Halloween gének expressziója csökkent (25. B ábra). Eredményeink alapján feltételezzük, hogy a dTAF10/dTAF10b tartalmú komplexek befolyásolják a gyürümirigyben expresszálódó Halloween gének transzkripcióját. A dTaf10 $0^{d 25}$ és a $d A d a 2 a^{d 189}$ mutánsok L3 végi-korai bábletális fenotípusa és a génexpressziós mintázatok hasonlóságai azt sugallják, hogy az ekdizon bioszintézisben részt vevő P450 citokróm gének transzkripcióját a dATAC, valamint a dTAF10/dTAF10b tartalmú komplexek együttesen szabályozhatják. 



25. ábra Ekdizon bioszintézisben részt vevő $\mathbf{P 4 5 0}$ citokróm gének expressziójának vizsgálata $d$ Taf $\boldsymbol{D}^{d 25}$ valamint $\boldsymbol{d A d a 2 a ^ { d 1 8 9 }}$ mutánsokban. A) P450 citokróm gének expressziós mintázatának összehasonlítása $d T a f 10^{d 25}$ és $d A d a 2 a^{d 189}$ mutánsokban, microarray adatok alapján. B) A Halloween gének expressziójának vizsgálata RT PCR módszerrel $d T a f 10^{d 25}$ és $w^{1118}$ Drosophila törzsekben. 


\section{Eredmények megvitatása}

\subsection{A dTAF10 fehériék szerepe a Drosophila fejlödésében}

A TFIID fontos szerepet játszik az eukarióta transzkripció szabályozásában. A transzkripció kezdő lépéseként a TBP-ből és a TAF fehérjékből álló TFIID fehérje komplex szerelődik össze és kötődik a gének promóter szakaszaihoz. A TFIID központi részében a hiszton-fold doméneket tartalmazó TAF4-TAF12, TAF6-TAF9 és a TAF8TAF10 fehérjék heterodimert képeznek [45] [92]. A TAF8-TAF10 fehérjéken kívül a TFIID központi részében a TAF4, TAF5, TAF6, TAF9 és a TAF12 fehérjék két kópiában vannak jelen és szimmetrikus szerkezetet alkotnak. Ehhez kapcsolódik a TAF8-TAF10 heterodimer, mely konformáció változást hoz létre [45]. A TAF10 tehát fontos szerepet játszik a TFIID szerveződésében. A TAF fehérjék nemcsak a TFIID fehérje komplexben, hanem más komplexben is előfordulnak, például hiszton acetiltranszferázokban. Az evolúciós fejlődés során a TAF fehérjéknek több változatuk jött létre, melyek különböző komplexek részeit képezik. Például a TAF5L, valamint a TAF6L is a SAGA komplex része, míg a TAF5 és a TAF6 a TFIID komplexben fordul elö. A humán sejtekben előforduló TAF10 fehérjének a Drosophilában két ortológja van, nevezetesen a dTAF10 és a dTAF10b. Wake és mtsai. Drosophila S2 sejtekben kimutatták, hogy a dTAF10b a dSAGA, a dTAF10 pedig a dTFIID része [21]. A két Drosophila dTAF10 fehérjét kódoló génszakaszok ellentétes irányultságúak, a promóter szakaszok átfednek egymással. A dTAF10 fehérjék funkcionális vizsgálatához dTAF10, illetve dTAF10b fehérjéket nem tartalmazó Drosophila vonalat hoztunk létre. Kísérleteinkben azt láttuk, hogy a dTAF10 és a dTAF10b fehérjéket nem tartalmazó állatok elérték az L3-as lárvastádiumot, azonban késői L3, illetve előbáb stádiumban elpusztultak. Korábbi kísérleteinkben azt tapasztaltuk, hogy a d25-ös deléció által okozott L3-végi, illetve bábletális fenotípus menekíthető dTaf10, és $d T a f 10 b$-t tartalmazó transzgénekkel. Habár a TAF10 és a TAF10b különböző komplexekben van jelen, feltételezhető, hogy a két fehérje részlegesen átfedő funkcióval rendelkezik. Az L3-végi, előbáb letalitás azért is kialakulhat, mert a korai lárvális fejlődési stádiumokban az anyai hatás miatt jelenlévő dTAF10, illetve dTAF10b mennyisége elegendő lehet ahhoz, hogy a dTAF10/dTAF10b hiányában létrejövő fenotípust menekítse. Ez alapján feltételezhető, hogy a dTAF10 fehérjék nemcsak az L3-előbáb stádiumban játszanak szerepet, hanem a korábbi lárvális fejlődésben is. 


\section{2. dTAF10 és dTAF10b hatása a dTFIID multiprotein komplexre}

A dTAF10 fehérjék alegységei a dTFIID és a dSAGA komplexnek is, viszont a dATAC komplexben nem fordulnak elö. Microarray kísérletek alapján megállapítottuk, hogy a dTAF10/dTAF10b fehérjék hiánya a kontrollhoz képest nagymértékü transzkripciós változást indukált. Feltételeztük, hogy a dSAGA komplex funkciókiesése állhat a háttérben. A microarray adatok további elemzése során azonban azt tapasztaltuk, hogy a dTAF10/dTAF10b hiányában kialakuló génexpressziós mintázat csak 5\%-a fed át a dSAGA ( $\left.d A d a 2 b^{d 842}\right)$ mutánsok génexpressziós változásaival. Mivel a dTAF10/dTAF10b fehérjék hiánya nemcsak a dSAGA, hanem a dTFIID funkcióit is befolyásolhatják, ezért feltételeztük, hogy a $d \operatorname{Tafl}^{d 25}$ mutánsokban kialakuló transzkripciós változások nagy része a dTFIID komplex funkciókiesése miatt következik be. Ezért vizsgáltuk, hogy a dTAF10 fehérjék hiánya hogyan szabályozza a dTFIID komplexet felépítő TAF-ok lokalizációját a kromoszómákon, illetve kialakulhat-e dTAF10 nélküli stabil dTFIID komplex. A kromoszóma festések során azt találtuk, hogy a dTAF10 hiányában a dTAF1, valamint a dTBP is jelen van a politén kromoszómán, viszont a dTAF5 mennyisége csökkent. Arra következtettünk, hogy dTAF10 fehérjék hiánya akadályozhatja a dTAF5 kötődését a gének promóter régióin, de a dTAF1, illetve dTBP kötődését nem zavarja. Western blottal megvizsgáltuk, hogy a dTAF10 fehérjék hiánya hogyan befolyásolja a dTAF1, dTAF5, dTAF6, illetve dTBP fehérje szintjét $d T a f 10^{d 25}$ lárvákban. Azt láttuk, hogy a dTAF1, dTAF5 fehérjeszintje csak kismértékben csökken a kontrollhoz képest, a dTBP és a dTAF6 fehérje szintje azonban szignifikáns csökkenést mutatott. Mivel a dTAF5 jelenléte csökkent a kromoszómákon, illetve a dTAF6 fehérje szintje csökkent a dTaf10 ${ }^{d 25}$ transzgenikus állatokban, ezért feltételeztük, hogy a dTAF10/dTAF10b hiánya nagymértékben szerepet játszik a dTFIID stabilitását befolyásoló szubkomplexek (dTAF4, dTAF5, dTAF6, dTAF9, dTAF12) összeszerelődésében. Ez okból vizsgáltuk meg, hogy a dTAF10, illetve dTAF10b hiányában kialakul-e a core dTFIID-ben jelenlévő dTAF4dTAF5 szubkomplex. Ko-immunprecipitációs kísérletben kimutattuk, hogy a dTFIID központi részében jelenlévő dTAF4-dTAF5 szubkomplex kialakul a dTaf10 d25 transzgenikus Drosophilákban. Eredményeink alapján azt feltételezzük, hogy a dTaf10 ${ }^{d 25}$ mutánsokban kialakulhat dTAF4-dTAF5 tartalmú dTFIID, azonban dTAF10/dTAF10b fehérjék hiánya egyes dTFIID alegységek - mint például a dTAF6 - degradációját okozhatja. Kísérleteink rávilágítanak arra, hogy a dTAF10 fehérjék befolyásolják a dTFIID összeszerelődését, mely hatással lehet az RNS polimeráz II kötődésére is. Immunfestések 
során azt láttuk, hogy az RNS polimeráz II jelen van a $d T a f 10^{d 25}$ mutánsok politén kromoszómáin. Feltételezhető, hogy a dTAF10/dTAF10b hiányában kialakulhat dTFIID nélküli funkcionális preiniciációs komplex.

Fenotípus vizsgálatok során azt találtuk, hogy dTAF10/dTAF10b fehérjét nem tartalmazó állatok L3-előbáb stádiumban elpusztulnak. Amikor azonban a dTaf10 125 mutáns lárvákat 20-hidroxi-ekdizonnal kiegészített táptalajon tartottuk fent, 34\%-al több lárva érte el az előbáb stádiumot a kontrollhoz képest. Ezért arra következtettünk, hogy az L3 végi-elöbáb letalitást az ekdizon hiánya okozhatja. Az ekdizon hiány kialakulásában több tényező is szerepet játszik. Az egyik lehetséges ok, hogy nem áll rendelkezésre megfelelő mennyiségü koleszterin, amiből később az ekdizon hormon szintetizálódik. Kísérleteink azonban azt mutatták, hogy a koleszterin nem menekíti az L3 végén bekövetkező letális fenotípust. Ezért valószínü, hogy az ekdizon hiánya nem a koleszterin felvétel hibája miatt alakul ki. Az ekdizon hiányos fenotípus azért is kialakulhat, mert a dTAF10 fehérjék befolyásolhatják a gyürümirigyben lezajló ekdizon szintézisét. Megvizsgáltuk, hogy a dTaf10 mRNS szintjének csökkenése specifikusan a gyürümirigyben milyen fenotípus változásokat eredményez. Azt találtuk, hogy a dTAF10 mRNS szintjének csökkentése specifikusan a gyürümirigyben a $d T a f 10^{d 25}$ mutánsokhoz hasonló L3-végi, illetve előbáb letalitást okozott, viszont ezt a fenotípust is 20-hidroxiekdizonnal sikerült menekíteni báb stádiumig. Ezek alapján feltételezhető, hogy a dTAF10 befolyásolhatja a gyürümirigyben végbemenő ekdizon szintézist. További kísérleteinknél azt láttuk, hogy nemcsak a $d T a f 10$, de a $d T a f 5$ és a $d T a f 8$ csendesítése a gyürümirigyben L3 végi letalitást okozott, melyet ekdizonnal sikerült báb stádiumig menekíteni. Ezért feltételezzük, hogy a dTAF5, dTAF8 és a dTAF10 tartalmú dTFIID fontos szerepet tölt be az L3 végi letális fenotípus kialakulásában. Mivel az ekdizon szintézis nagyrészt a gyürümirigy sejtjeiben történik, ezért a $d T a f 10^{d 25}$ mutánsoknál az L3 végi letalitást a gyürümirigy szöveti degradációja is okozhatja. A gyürümirigy morfológiai vizsgálatánál azonban azt tapasztaltuk, hogy a $d T a f 10^{d 25}$ mutánsokban a gyürümirigy nem degradálódott.

Korábban laborunk kimutatta hogy az $d A d a 2 a^{d 189}$ (dATAC) mutánsokban az ekdizon bioszintézisben részt vevő p450 citokróm gének expressziója lecsökken, valamint a dATAC mutánsok, a dTaf10 $0^{d 25}$ mutánsokhoz hasonlóan, L3 végi-korai báb stádiumban pusztulnak el [88]. Továbbá láttuk azt is, hogy a dADA2a, valamint a dTAF10 fehérjék hiányában kialakuló expressziós változások nagymértékben átfednek egymással. Ezért megvizsgáltuk, hogy az ekdizon bioszintézisben részt vevő gének expressziója hogyan változik dTAF10/dTAF10b hiányában. Eredményeinkből az látszott, hogy a dTaf10 $0^{d 25}$ 
mutánsokban a gyürümirigyben expresszálódó Halloween gének expressziója csökken, ugyanakkor a perifériás szövetekben expresszálódó shade mRNS szintje nő a kontrollhoz képest. A microarray adatok azt mutatták, hogy mind a dATAC, mind a dTaf10 125 mutánsokban hasonló mértékben változik a citokróm P450 gének expressziója. Ezek alapján feltételezzük, hogy a dTAF10 mutánsokban kialakuló ekdizon hiány nagyrészt a gyürümirigyben kifejeződő citokróm P450 gének expressziócsökkenése miatt következik be. Emellett megállapíthatjuk, hogy a dTAF10/dTAF10b tartalmú komplexek a dATAC komplexekkel együtt szabályozhatják az ekdizon bioszintézisben résztvevő citokróm P450 gének transzkripcióját.

A Drosophila melanogaster lárvális egyedfejlődése során több ekdizon csúcsot is megfigyelhetünk. A legnagyobb ekdizon hullám a bábozódás előtt alakul ki, 92 órával a petéből való kikelés után [93] [94]. Az ekdizon szintjének növekedése indukálja a bábban a politén lárvális szövetek apoptózissal történő pusztulását, majd a lárvális diploid imaginális diszkuszokból kialakulnak a felnőtt állatok szervei. Ezalatt nagymértékü transzkripciós változások következnek be. Feltételezhető, hogy a dTAF10 fehérjéket nem tartalmazó lárvákban az ekdizon hormon által indukált transzkripciós változások nem mennek végbe.

\subsection{A dTAF10 fehérie tartalmú komplexek valamint a dATAC kapcsolata}

Microarray vizsgálatok során azt tapasztaltuk, hogy a $d A d a 2 a^{d 189}$ (dATAC) és a Taf10 ${ }^{d 25}$ mutánsok génexpressziós változásai nagymértékben hasonlóak. Emellett mind a dATAC komplex, mind a dTAF10/dTAF10b fehérje tartalmú komplexek fontos szerepet játszanak a Halloween gének transzkripciójának szabályozásában. Elképzelhető, hogy a dATAC, valamint a dTAF10/dTAF10b tartalmú komplexek (valószínűleg dTFIID komplex) közötti funkcionális kapcsolat a Halloween gének transzkripciójának szabályozásán keresztül valósul meg. Korábban kimutatták, hogy az ATAC komplex képes kölcsönhatást kialakítani a TBP-vel in vivo [95]. Lehetséges, hogy a dATAC, valamint a dTBP együttes szabályozása szükséges a Halloween gének aktiválásához.

A TFIID legnagyobb alegysége a dTAF1, mely több enzimaktivitású doménnal rendelkezik. A Bromodoménjain keresztül képes kölcsönhatást kialakítani a tetra-acetilált H4 fehérjével (H4K5, K8, K12, K16). A TAF1 szerepe itt feltételezhetően a TFIID pozícionálása lehet. Emellett a $\mathrm{H} 4 \mathrm{~K} 5, \mathrm{~K} 8, \mathrm{~K} 12$ acetilációja a transzkripció aktiválásával függ össze [96]. Ezek alapján feltételezhető, hogy a TAF1 az acetilált H4-en a promóter szakaszok felismerésében vesz részt. Lehetséges, hogy a dATAC által okozott H4K5-, K12 
acetiláció elősegíti a TFIID kötődését a gének promóter részein, ezáltal a transzkripció fokozódik.

\subsection{A dTAF10 fehérje tartalmú komplexek és a dSAGA kapcsolata}

A dTAF10/dTAF10b hiánya érintheti mind a dSAGA, mind pedig a dTFIID funkcióját is. Laborunkban korábban kimutatták, hogy a $d A d a 2 b^{d 842}$ mutánsokban megváltozik a dTAF10 mintázata a nyálmirigy óriáskromoszómáin [32]. Elképzelhető, hogy a dTAF10 lokalizációja azért változik meg $d A d a 2 b^{d 842}$ mutánsban, mert a dSAGA specifikus acetiláció által kialakított nyitottabb kromatin szerkezet nem alakul ki, mely szükséges ahhoz, hogy a dTAF10 tartalmú dTFIID kötődhessen egyes gének promóter régióihoz. A dTaf10 ${ }^{d 25}$ mutánsban a dTAF10/dTAF10b fehérjék hiánya a dSAGA, valamint a dTFIID komplex stabilitását is befolyásolhatja. A dTaf10 ${ }^{d 25}$ mutánsokban megváltozik az dADA2b specifikus H3K14 acetilációjának a mintázata, viszont a H3K9 acetilációja, valamint dADA2b lokalizációja nem változik a kontrollhoz képest. Feltételezhető, hogy a dTAF10/dTAF10b fehérjék hiányában részleges dSAGA komplex szerelödik össze. 


\section{Köszönetnyilvánítás}

Köszönettel tartozom témavezetöimnek, Prof. Dr. Boros Imrének és Dr. Pankotai Tibornak, hogy munkámat mindvégig lelkiismeretesen irányították és szakmai tanácsukkal segítették kutatásaimat. Köszönöm a türelmüket és bizalmukat, valamint a lehetőséget, hogy kutatócsoportjukban dolgozhattam.

Köszönet illeti Borsos Barbara Nikolettet, aki a PCR kísérletek során szakmai segítséget nyújtott és segítette a doktori munkámat.

Köszönöm Dr. Villányi Zoltánnak, hogy segítette munkámat és szakmai előmenetelemet.

Emellett köszönöm Dr. Bodai Lászlónak, Dr. Zsindely Nórának és Grézal Gábornak, hogy hasznos tanácsaikkal segítették a kutatásaimat.

Köszönöm a Biokémiai és Molekuláris Biológiai Tanszék összes jelenlegi és volt munkatársának, hogy munkájukkal támogattak, segítettek. Külön köszönet CsebellaBakota Adriennek és Pataki Edinának, Dr. Hermesz Editnek, Ökrösné Katalinnak a kísérletekben nyújtott segítségükért.

Nem utolsó sorban köszönöm családomnak, hogy mindvégig mellettem álltak és támogattak. 


\section{Irodalomjegyzék}

1. Luger K, Mäder AW, Richmond RK, Sargent DF, Richmond TJ. Crystal structure of the nucleosome core particle at 2.8 A resolution. Nature. 1997;389: 251-260. doi: $10.1038 / 38444$

2. Chodaparambil J V., Edayathumangalam RS, Bao Y, Park YJ, Luger K.

Nucleosome structure and function. Ernst Schering Research Foundation Workshop. 2006; 29-46.

3. Benjamin A. Pierce. Genetics: A Conceptual Approach, 2nd ed.

4. Mutskov V, Gerber D, Angelov D, Ausio J, Workman J, Dimitrov S. Persistent Interactions of Core Histone Tails with Nucleosomal DNA following Acetylation and Transcription Factor Binding. Molecular and Cellular Biology. 1998;18: 62936304.

5. Shogren-Knaak M, Ishii H, Sun J-M, Pazin MJ, Davie JR, Peterson CL. Histone H4K16 acetylation controls chromatin structure and protein interactions. Science (New York, NY). 2006;311: 844-847. doi:10.1126/science.1124000

6. Kouzarides T. Chromatin modifications and their function. Cell. 2007;128: 693705. doi:10.1016/j.cell.2007.02.005

7. Fischle W, Tseng BS, Dormann HL, Ueberheide BM, Garcia BA, Shabanowitz J, et al. Regulation of HP1-chromatin binding by histone $\mathrm{H} 3$ methylation and phosphorylation. doi:10.1038/nature04219

8. Lee KK, Workman JL. Histone acetyltransferase complexes: one size doesn't fit all. Nature Reviews Molecular Cell Biology. 2007;8: 284-295. doi:10.1038/nrm2145

9. Kuo MH, Brownell JE, Sobel RE, Ranalli TA, Cook RG, Edmondson DG, et al. Transcription-linked acetylation by Gen5p of histones H3 and H4 at specific lysines. Nature. 1996;383: 269-272. doi:10.1038/383269a0

10. Grant PA, Eberharter A, John S, Cook RG, Turner BM, Workman JL. Expanded lysine acetylation specificity of Gen5 in native complexes. The Journal of Biological Chemistry. 1999;274: 5895-5900.

11. Xu W, Edmondson DG, Roth SY. Mammalian GCN5 and P/CAF acetyltransferases have homologous amino-terminal domains important for recognition of nucleosomal substrates. Molecular and Cellular Biology. 1998;18: 5659-5669.

12. Martinez E, Palhan VB, Tjernberg A, Lymar ES, Gamper AM, Kundu TK, et al. Human STAGA complex is a chromatin-acetylating transcription coactivator that interacts with pre-mRNA splicing and DNA damage-binding factors in vivo. Molecular and Cellular Biology. 2001;21: 6782-6795. doi:10.1128/MCB.21.20.6782-6795.2001

13. Spedale G, Timmers HTM, Pijnappel WWMP. ATAC-king the complexity of SAGA during evolution. Genes \& Development. 2012;26: 527-541. doi:10.1101/gad.184705.111

14. Jenny Wu P-Y, Ruhlmann C, Winston F, Schultz P. Molecular Architecture of the S. cerevisiae SAGA Complex. Molecular Cell. 2004;15: 199-208.

15. Wu P-YJ, Winston F. Analysis of Spt7 function in the Saccharomyces cerevisiae SAGA coactivator complex. Molecular and Cellular Biology. 2002;22: 5367-5379.

16. Xu C, Min J. Structure and function of WD40 domain proteins. Protein \& Cell. 
2011;2: 202-214. doi:10.1007/s13238-011-1018-1

17. Ogryzko V V., Kotani T, Zhang X, Schiltz RL, Howard T, Yang XJ, et al. Histonelike TAFs within the PCAF histone acetylase complex. Cell. 1998;94: 35-44.

18. Frontini M, Soutoglou E, Argentini M, Bole-Feysot C, Jost B, Scheer E, et al. TAF9b (formerly TAF9L) is a bona fide TAF that has unique and overlapping roles with TAF9. Molecular and Cellular Biology. 2005;25: 4638-4649.

doi:10.1128/MCB.25.11.4638-4649.2005

19. Georgieva S, Kirschner DB, Jagla T, Nabirochkina E, Hanke S, Schenkel H, et al. Two novel Drosophila TAF(II)s have homology with human TAF(II)30 and are differentially regulated during development. Molecular and Cellular Biology. 2000;20: 1639-1648.

20. Grant PA, Schieltz D, Pray-Grant MG, Steger DJ, Reese JC, Yates JR, et al. A subset of TAF(II)s are integral components of the SAGA complex required for nucleosome acetylation and transcriptional stimulation. Cell. 1998;94: 45-53.

21. Weake VM, Swanson SK, Mushegian A, Florens L, Washburn MP, Abmayr SM, et al. A novel histone fold domain-containing protein that replaces TAF6 in Drosophila SAGA is required for SAGA-dependent gene expression. Genes \& Development. 2009;23: 2818-2823. doi:10.1101/gad.1846409

22. Lee KK, Sardiu ME, Swanson SK, Gilmore JM, Torok M, Grant PA, et al. Combinatorial depletion analysis to assemble the network architecture of the SAGA and ADA chromatin remodeling complexes. Molecular Systems Biology. 2011;7: 503. doi:10.1038/msb.2011.40

23. Orpinell M, Fournier M, Riss A, Nagy Z, Krebs AR, Frontini M, et al. The ATAC acetyl transferase complex controls mitotic progression by targeting non-histone substrates. The EMBO journal. 2010;29: 2381-2394. doi:10.1038/emboj.2010.125

24. Barlev NA, Emelyanov A V., Castagnino P, Zegerman P, Bannister AJ, Sepulveda MA, et al. A Novel Human Ada2 Homologue Functions with Gcn5 or Brg1 To Coactivate Transcription. Molecular and Cellular Biology. 2003;23: 6944-6957. doi:10.1128/MCB.23.19.6944-6957.2003

25. Muratoglu S, Georgieva S, Pápai G, Scheer E, Enünlü I, Komonyi O, et al. Two Different Drosophila ADA2 Homologues Are Present in Distinct GCN5 Histone Acetyltransferase-Containing Complexes. Molecular and Cellular Biology. 2003;23: 306-321. doi:10.1128/MCB.23.1.306-321.2003

26. Mujtaba S, Zeng L, Zhou M-M. Structure and acetyl-lysine recognition of the bromodomain. Oncogene. 2007;26: 5521-5527. doi:10.1038/sj.onc.1210618

27. Qian C, Zhang Q, Li S, Zeng L, Walsh MJ, Zhou M-M. Structure and chromosomal DNA binding of the SWIRM domain. Nature Structural \& Molecular Biology. 2005;12: 1078-1085. doi:10.1038/nsmb1022

28. Guelman S, Suganuma T, Florens L, Swanson SK, Kiesecker CL, Kusch T, et al. Host cell factor and an uncharacterized SANT domain protein are stable components of ATAC, a novel dAda2A/dGcn5-containing histone acetyltransferase complex in Drosophila. Molecular and cellular biology. 2006;26: 871-82. doi:10.1128/MCB.26.3.871-882.2006

29. Suganuma T, Gutiérrez JL, Li B, Florens L, Swanson SK, Washburn MP, et al. ATAC is a double histone acetyltransferase complex that stimulates nucleosome sliding. Nature structural \& molecular biology. 2008;15: 364-72. 
doi:10.1038/nsmb.1397

30. Nagy Z, Riss A, Fujiyama S, Krebs A, Orpinell M, Jansen P, et al. The metazoan ATAC and SAGA coactivator HAT complexes regulate different sets of inducible target genes. Cellular and molecular life sciences : CMLS. 2010;67: 611-28. doi:10.1007/s00018-009-0199-8

31. Ciurciu A, Komonyi O, Pankotai T, Boros IM. The Drosophila Histone Acetyltransferase Gcn5 and Transcriptional Adaptor Ada2a Are Involved in Nucleosomal Histone H4 Acetylation. Molecular and Cellular Biology. 2006;26: 9413-9423. doi:10.1128/MCB.01401-06

32. Pankotai T, Komonyi O, Bodai L, Ujfaludi Z, Muratoglu S, Ciurciu A, et al. The homologous Drosophila transcriptional adaptors ADA2a and ADA2b are both required for normal development but have different functions. Molecular and Cellular Biology. 2005;25: 8215-8227. doi:10.1128/MCB.25.18.8215-8227.2005

33. Basehoar AD, Zanton SJ, Pugh BF. Identification and distinct regulation of yeast TATA box-containing genes. Cell. 2004;116: 699-709.

34. Rhee HS, Pugh BF. Genome-wide structure and organization of eukaryotic preinitiation complexes. Nature. 2012;483: 295-301. doi:10.1038/nature10799

35. Deng W, Malecová B, Oelgeschläger T, Roberts SGE. TFIIB recognition elements control the TFIIA-NC2 axis in transcriptional regulation. Molecular and Cellular Biology. 2009;29: 1389-1400. doi:10.1128/MCB.01346-08

36. West RW, Yocum RR, Ptashne M. Saccharomyces cerevisiae GALJ-GALJO Divergent Promoter Region: Location and Function of the Upstream Activating Sequence UASG. MOLECULAR AND CELLULAR BIOLOGY. 1984; 2467-2478.

37. Larivière L, Seizl M, Cramer P. A structural perspective on Mediator function. Current Opinion in Cell Biology. 2012;24: 305-313. doi:10.1016/j.ceb.2012.01.007

38. Wang Q, Carroll JS, Brown M. Spatial and Temporal Recruitment of Androgen Receptor and Its Coactivators Involves Chromosomal Looping and Polymerase Tracking. Molecular Cell. 2005;19: 631-642. doi:10.1016/j.molcel.2005.07.018

39. Sainsbury S, Bernecky C, Cramer P. Structural basis of transcription initiation by RNA polymerase II. Nature Reviews Molecular Cell Biology. 2015;16: 129-143. doi:10.1038/nrm3952

40. Liu X, Kraus WL, Bai X. Ready, pause, go: regulation of RNA polymerase II pausing and release by cellular signaling pathways. Trends in Biochemical Sciences. 2015;40: 516-525. doi:10.1016/j.tibs.2015.07.003

41. Thomas MC, Chiang C-M. The general transcription machinery and general cofactors. Critical Reviews in Biochemistry and Molecular Biology. 2006;41: 105178. doi:10.1080/10409230600648736

42. Cler E, Papai G, Schultz P, Davidson I. Recent advances in understanding the structure and function of general transcription factor TFIID. Cellular and molecular life sciences: CMLS. 2009;66: 2123-2134. doi:10.1007/s00018-009-0009-3

43. Papai G, Tripathi MK, Ruhlmann C, Layer JH, Weil PA, Schultz P. TFIIA and the transactivator Rap1 cooperate to commit TFIID for transcription initiation. Nature. 2010;465: 956-960. doi:10.1038/nature09080

44. Sanders SL, Garbett KA, Weil PA. Molecular characterization of Saccharomyces cerevisiae TFIID. Molecular and Cellular Biology. 2002;22: 6000-6013. 
45. Bieniossek C, Papai G, Schaffitzel C, Garzoni F, Chaillet M, Scheer E, et al. The architecture of human general transcription factor TFIID core complex. Nature. 2013;493: 699-702. doi:10.1038/nature11791

46. Hoffmann A, Chiang C-M, Oelgeschläger T, Xie X, Burley SK, Nakatani Y, et al. A histone octamer-like structure within TFIID. Nature. 1996;380: 356-359. doi:10.1038/380356a0

47. Soutoglou E, Demény MA, Scheer E, Fienga G, Sassone-Corsi P, Tora L. The Nuclear Import of TAF10 Is Regulated by One of Its Three Histone Fold DomainContaining Interaction Partners. Molecular and Cellular Biology. 2005;25: 40924104. doi:10.1128/MCB.25.10.4092-4104.2005

48. Wright KJ, Marr MT, Tjian R. TAF4 nucleates a core subcomplex of TFIID and mediates activated transcription from a TATA-less promoter. Proceedings of the National Academy of Sciences of the United States of America. 2006;103: 1234712352. doi:10.1073/pnas.0605499103

49. Dynlacht BD, Hoey T, Tjian R. Isolation of coactivators associated with the TATAbinding protein that mediate transcriptional activation. Cell. 1991;66: 563-576.

50. Tanese N, Pugh BF, Tjian R. Coactivators for a proline-rich activator purified from the multisubunit human TFIID complex. Genes \& Development. 1991;5: 22122224.

51. Tora L. A unified nomenclature for TATA box binding protein (TBP)-associated factors (TAFs) involved in RNA polymerase II transcription. Genes \& Development. 2002;16: 673-675.

52. Burley SK, Roeder RG. Biochemistry and structural biology of transcription factor IID (TFIID). Annual Review of Biochemistry. 1996;65: 769-799. doi:10.1146/annurev.bi.65.070196.004005

53. Gangloff Y-G, Werten S, Romier C, Carré L, Poch O, Moras D, et al. The Human TFIID Components TAFII135 and TAFII20 and the Yeast SAGA Components ADA1 and TAFII68 Heterodimerize to Form Histone-Like Pairs. Molecular and Cellular Biology. 2000;20: 340-351.

54. Xie X, Kokubo T, Cohen SL, Mirza UA, Hoffmann A, Chait BT, et al. Structural similarity between TAFs and the heterotetrameric core of the histone octamer. Nature. 1996;380: 316-322. doi:10.1038/380316a0

55. Selleck W, Howley R, Fang Q, Podolny V, Fried MG, Buratowski S, et al. A histone fold TAF octamer within the yeast TFIID transcriptional coactivator. Nature Structural \& Molecular Biology. 2001;8: 695-700. doi:10.1038/90408

56. Trowitzsch S, Viola C, Scheer E, Conic S, Chavant V, Fournier M, et al. Cytoplasmic TAF2-TAF8-TAF10 complex provides evidence for nuclear holoTFIID assembly from preformed submodules. Nature Communications. 2015;6. doi:10.1038/ncomms7011

57. Gangloff YG, Romier C, Thuault S, Werten S, Davidson I. The histone fold is a key structural motif of transcription factor TFIID. Trends in Biochemical Sciences. 2001;26: 250-257.

58. Gangloff YG, Pointud JC, Thuault S, Carré L, Romier C, Muratoglu S, et al. The TFIID components human TAF(II)140 and Drosophila BIP2 (TAF(II)155) are novel metazoan homologues of yeast TAF(II)47 containing a histone fold and a PHD finger. Molecular and Cellular Biology. 2001;21: 5109-5121. 
doi:10.1128/MCB.21.15.5109-5121.2001

59. Leurent C, Sanders S, Ruhlmann C, Mallouh V, Weil PA, Kirschner DB, et al. Mapping histone fold TAFs within yeast TFIID. The EMBO Journal. 2002;21: 3424-3433. doi:10.1093/emboj/cdf342

60. Callebaut I, Prat K, Meurice E, Mornon J-P, Tomavo S. Prediction of the general transcription factors associated with RNA polymerase II in Plasmodium falciparum: conserved features and differences relative to other eukaryotes. BMC genomics. 2005;6: 100. doi:10.1186/1471-2164-6-100

61. Malkowska M, Kokoszynska K, Rychlewski L, Wyrwicz L. Structural bioinformatics of the general transcription factor TFIID. Biochimie. 2013;95: 680691. doi:10.1016/j.biochi.2012.10.024

62. Wassarman DA, Sauer F. TAF(II)250: a transcription toolbox. Journal of Cell Science. 2001;114: 2895-2902.

63. Pham AD, Sauer F. Ubiquitin-activating/conjugating activity of TAFII250, a mediator of activation of gene expression in Drosophila. Science (New York, NY). 2000;289: 2357-2360.

64. Liu D, Ishima R, Tong KI, Bagby S, Kokubo T, Muhandiram DR, et al. Solution structure of a TBP-TAF(II)230 complex: protein mimicry of the minor groove surface of the TATA box unwound by TBP. Cell. 1998;94: 573-583.

65. Jacobson RH, Ladurner AG, King DS, Tjian R. Structure and function of a human TAFII250 double bromodomain module. Science (New York, NY). 2000;288: $1422-1425$.

66. Bhattacharya S, Takada S, Jacobson RH. Structural analysis and dimerization potential of the human TAF5 subunit of TFIID. Proceedings of the National Academy of Sciences of the United States of America. 2007;104: 1189-1194. doi:10.1073/pnas.0610297104

67. Mitsuzawa H, Ishihama A. Identification of histone H4-like TAF in Schizosaccharomyces pombe as a protein that interacts with WD repeat-containing TAF. Nucleic Acids Research. 2002;30: 1952-1958.

68. Theisen JWM, Lim CY, Kadonaga JT. Three key subregions contribute to the function of the downstream RNA polymerase II core promoter. Molecular and cellular biology. 2010;30: 3471-9. doi:10.1128/MCB.00053-10

69. Burke TW, Kadonaga JT. The downstream core promoter element, DPE, is conserved from Drosophila to humans and is recognized by TAFII60 of Drosophila. Genes \& development. 1997;11: 3020-31.

70. Jacq X, Brou C, Lutz Y, Davidson I, Chambon P, Tora L. Human TAFII30 is present in a distinct TFIID complex and is required for transcriptional activation by the estrogen receptor. Cell. 1994;79: 107-117. doi:10.1016/0092-8674(94)90404-9

71. Metzger D, Scheer E, Soldatov A, Tora L. Mammalian TAF(II)30 is required for cell cycle progression and specific cellular differentiation programmes. The EMBO Journal. 1999;18: 4823-4834. doi:10.1093/emboj/18.17.4823

72. Kirchner J, Sanders SL, Klebanow E, Weil PA. Molecular Genetic Dissection of TAF25, an Essential Yeast Gene Encoding a Subunit Shared by TFIID and SAGA Multiprotein Transcription Factors. Molecular and Cellular Biology. 2001;21: 66686680. doi:10.1128/MCB.21.19.6668-6680.2001 
73. Kirschner DB, vom Baur E, Thibault C, Sanders SL, Gangloff Y-G, Davidson I, et al. Distinct Mutations in Yeast TAFII25 Differentially Affect the Composition of TFIID and SAGA Complexes as Well as Global Gene Expression Patterns.

Molecular and Cellular Biology. 2002;22: 3178-3193. doi:10.1128/MCB.22.9.31783193.2002

74. Walker AK, Rothman JH, Shi Y, Blackwell TK. Distinct requirements for C.elegans TAFIIs in early embryonic transcription. The EMBO Journal. 2001;20: 5269-5279. doi:10.1093/emboj/20.18.5269

75. Mohan II WS, Scheer E, Wendling O, Metzger D, Tora L. TAF10 (TAFII30) Is Necessary for TFIID Stability and Early Embryogenesis in Mice. Molecular and Cellular Biology. 2003;23: 4307-4318. doi:10.1128/MCB.23.12.4307-4318.2003

76. Georgieva S, Kirschner DB, Jagla T, Nabirochkina E, Hanke S, Schenkel H, et al. Two Novel Drosophila TAFIIs Have Homology with Human TAFII30 and Are Differentially Regulated during Development. Molecular and Cellular Biology. 2000;20: 1639-1648.

77. Oey NA, Ijlst L, van Roermund CWT, Wijburg FA, Wanders RJA. dif-1 and colt, both implicated in early embryonic development, encode carnitine acylcarnitine translocase. Molecular Genetics and Metabolism. 2005;85: 121-124. doi:10.1016/j.ymgme.2005.02.012

78. Francis R, McGrath G, Zhang J, Ruddy DA, Sym M, Apfeld J, et al. aph-1 and pen2 are required for Notch pathway signaling, gamma-secretase cleavage of betaAPP, and presenilin protein accumulation. Developmental Cell. 2002;3: 85-97.

79. Nijhout HF. The control of body size in insects. Developmental biology. 2003;261: $1-9$.

80. Colombani J, Bianchini L, Layalle S, Pondeville E, Dauphin-Villemant C, Antoniewski C, et al. Antagonistic actions of ecdysone and insulins determine final size in Drosophila. Science (New York, NY). 2005;310: 667-70. doi:10.1126/science.1119432

81. Marchal E, Vandersmissen HP, Badisco L, Van de Velde S, Verlinden H, Iga M, et al. Control of ecdysteroidogenesis in prothoracic glands of insects: a review. Peptides. 2010;31: 506-19. doi:10.1016/j.peptides.2009.08.020

82. Walkiewicz MA, Stern M. Increased insulin/insulin growth factor signaling advances the onset of metamorphosis in Drosophila. PloS one. 2009;4: e5072. doi:10.1371/journal.pone.0005072

83. Rewitz KF, Yamanaka N, Gilbert LI, O'Connor MB. The insect neuropeptide PTTH activates receptor tyrosine kinase torso to initiate metamorphosis. Science (New York, NY). 2009;326: 1403-5. doi:10.1126/science.1176450

84. Rewitz KF, Rybczynski R, Warren JT, Gilbert LI. The Halloween genes code for cytochrome P450 enzymes mediating synthesis of the insect moulting hormone. Biochemical Society Transactions. 2006;34: 1256-1260. doi:10.1042/BST0341256

85. Mirth CK, Riddiford LM. Size assessment and growth control: how adult size is determined in insects. BioEssays : news and reviews in molecular, cellular and developmental biology. 2007;29: 344-55. doi:10.1002/bies.20552

86. Petryk A, Warren JT, Marqués G, Jarcho MP, Gilbert LI, Kahler J, et al. Shade is the Drosophila P450 enzyme that mediates the hydroxylation of ecdysone to the steroid insect molting hormone 20-hydroxyecdysone. Proceedings of the National 
Academy of Sciences of the United States of America. 2003;100: 13773-13778. doi:10.1073/pnas.2336088100

87. Gilbert LI. Halloween genes encode P450 enzymes that mediate steroid hormone biosynthesis in Drosophila melanogaster. Molecular and Cellular Endocrinology. 2004;215: 1-10. doi:10.1016/j.mce.2003.11.003

88. Pankotai T, Popescu C, Martín D, Grau B, Zsindely N, Bodai L, et al. Genes of the ecdysone biosynthesis pathway are regulated by the dATAC histone acetyltransferase complex in Drosophila. Molecular and Cellular Biology. 2010;30: 4254-4266. doi:10.1128/MCB.00142-10

89. Zsindely N, Pankotai T, Ujfaludi Z, Lakatos D, Komonyi O, Bodai L, et al. The loss of histone $\mathrm{H} 3$ lysine 9 acetylation due to dSAGA-specific dAda2b mutation influences the expression of only a small subset of genes. Nucleic Acids Research. 2009;37: 6665-6680. doi:10.1093/nar/gkp722

90. Hansen SK, Takada S, Jacobson RH, Lis JT, Tjian R. Transcription properties of a cell type-specific TATA-binding protein, TRF. Cell. 1997;91: 71-83.

91. Pankotai T, Popescu C, Martín D, Grau B, Zsindely N, Bodai L, et al. Genes of the Ecdysone Biosynthesis Pathway Are Regulated by the dATAC Histone Acetyltransferase Complex in Drosophila. Molecular and Cellular Biology. 2010;30: 4254-4266. doi:10.1128/MCB.00142-10

92. Demény MA, Soutoglou E, Nagy Z, Scheer E, Jànoshàzi A, Richardot M, et al. Identification of a small TAF complex and its role in the assembly of TAFcontaining complexes. PloS One. 2007;2: e316. doi:10.1371/journal.pone.0000316

93. White KP, Rifkin SA, Hurban P, Hogness DS. Microarray analysis of Drosophila development during metamorphosis. Science (New York, NY). 1999;286: 21792184.

94. Beckstead RB, Lam G, Thummel CS. The genomic response to 20hydroxyecdysone at the onset of Drosophila metamorphosis. Genome Biology. 2005;6: R99. doi:10.1186/gb-2005-6-12-r99

95. Wang Y-L, Faiola F, Xu M, Pan S, Martinez E. Human ATAC Is a GCN5/PCAFcontaining Acetylase Complex with a Novel NC2-like Histone Fold Module That Interacts with the TATA-binding Protein. The Journal of Biological Chemistry. 2008;283: 33808-33815. doi:10.1074/jbc.M806936200

96. Morinière J, Rousseaux S, Steuerwald U, Soler-López M, Curtet S, Vitte A-L, et al. Cooperative binding of two acetylation marks on a histone tail by a single bromodomain. Nature. 2009;461: 664-668. doi:10.1038/nature08397 


\section{Tartalmi összefoglaló}

Eukariótákban a transzkripció iniciáció első lépése során a TFIID kötődik az átírandó gének promóter szakaszaihoz. A TFIID a gének promóter szakaszain elhelyezkedő TATA szekvenciához kötődő TBP-ből, valamint TBP-hez kapcsolódó TAF fehérjékből áll. A humán és a Drosophila dTFIID központi részében előforduló TAF-ok összetétele megegyezik. A TAF4, TAF5, TAF6, TAF9, és TAF12 fehérjék kétszer vannak jelen, és kétoldali szimmetrikus „core” dTFIID komplexet alkotnak, melyhez kapcsolódik a TAF8-TAF10 heterodimer és konformációváltozást okoz a dTFIID-ben. A 7 különbözö TAF fehérjéből álló komplexhez kapcsolódik a többi TAF fehérje valamint a TBP is, melyek egyszer fordulnak elő a komplexben. Számos TAF fehérje azonban nemcsak a dTFIID komplex része, hanem hiszton acetiltranszferáz (HAT) komplexekben is előfordulnak. A HAT fehérjék acetil-koenzim A-ról az acetil-csoport áthelyezését katalizálják hiszton fehérjék lizin aminosavjaira, ezáltal egy nyitottabb kromatin szerkezet alakulhat ki. Drosophilában két GCN5 tartalmú hiszton acetiltranszferáz (HAT) komplex van jelen a dSAGA és az dATAC. Mind a dSAGA, mind az dATAC komplex több alegységböl épülnek fel, melyek közül az ADA3, a GCN5 és az SGF29 mindkét komplexben megtalálható. Ez a három alegység és a hozzájuk kapcsolódó rokon szerkezetủ ADA2a (ATAC) és ADA2b (SAGA) fehérjék alkotják mindkét komplexben az acetiltranszferáz modult. A közös alegységek ellenére az dATAC és a dSAGA komplex eltérő biológiai folyamatok szabályozásában vesznek részt. A két komplex eltérő szubsztrát specificitással rendelkezik, a $\mathrm{H} 3$ 9-es és 14-es lizin acetiláció dSAGA specifikus, míg a H4 5-ös és 12-es lizin acetilációban az dATAC játszik szerepet.

Drosophila melanogaster-ben két TAF10 homológ fehérjét azonosítottak (dTAF10$\mathrm{t}$ és dTAF10b-t), melyeknek funkciója eddig ismeretlen volt. A dTAF10 és a dTAF10b fehérje funkcionális vizsgálatához olyan dTAF10 fehérjéket nem tartalmazó Drosophila vonalakat hoztunk létre, melyekben mindkét dTAF10 fehérjét kódoló génszakasz hiányzik. Habár a dTAF10b fehérje a dSAGA acetiltranszferáz komplex része, a dTAF10/dTAF10b hiányos állatok transzkriptóm analízise az dATAC $\left(d A d a 2 a^{d 189}\right)$ mutánsokhoz hasonló gén 
expressziós változásokat eredményezett. Ezekből az eredményekből arra következtettünk, hogy az dATAC és a dTAF10/dTAF10b tartalmú dTFIID komplex hasonló biológiai útvonalak szabályozásában vehetnek részt. Ezért a további célkitüzéseink között szerepelt annak kiderítése, hogy az dATAC és a dTAF10/dTAF10b tartalmú komplexek között milyen funkcionális kapcsolat található.

Immunfestéssel vizsgáltuk, hogy a dTAF10/dTAF10b hiánya hogyan befolyásolja a dSAGA specifikus H3K9-, H3K14-, valamint a dATAC specifikus H4K12 és a GCN5 függő H4K8-acetiláció szintjét a politén kromoszómákon. Azt tapasztaltuk, hogy az dATAC specifikus H4K12- és a GCN5 specifikus H4K8-acetiláció szintje nem változott, míg a dSAGA specifikus H3K14-acetiláció szintje csökkent a kontrollhoz viszonyítva. Kísérleteink megerősítik, hogy a dTAF10b a dSAGA komplex része és dTAF10/dTAF10b hiányában a komplex csak részben képes ellátni a feladatát.

További kísérleteinkben Drosophila politén kromoszómákon végzett immunfestéssel vizsgáltuk, hogy dTAF10 fehérjék hiányában megfigyelhetö-e a dTFIID és a dSAGA alegységek jelenléte. Azt tapasztaltuk, hogy a dTAF10 fehérjéket nem tartalmazó Drosophila vonalakban a dTAF5 fehérje mennyisége csökken a kromoszómákon, azonban a dTAF1 és a dTBP jelenléte a kontrollhoz képest nem változik. Továbbá az dADA2b dSAGA alegység lokalizációja sem változik a kontrollhoz viszonyítva a kromoszómák különböző régióiban. Ezért feltételezzük, hogy a dTAF10/dTAF10b hiányában kialakuló dSAGA specifikus H3K14 acetilációjának csökkenését nem az ADA2b degradációja okozza a dTaf10 ${ }^{d 25}$ mutánsokban. Mivel a dTAF5 fehérjeszintjének csökkenése a politén kromoszómákon a dTFIID degradációját is elöidézheti, ezért analizáltuk, hogy a $d T A F 10^{d 25}$ mutánsokban kialakulhat-e a dTAF4dTAF5 tartalmú szubkomplex, melynek központi szerepe van a dTFIID komplex integritásának fenntartásában. Ko-immunprecipitációval azt tapasztaltuk, hogy a dTAF4 és dTAF5 fehérjék közti kölcsönhatás kimutatható a kontroll és a dTAF10/dTAF10b fehérjéket nem tartalmazó transzgenikus lárvákban is. Eredményeink alapján ezért arra következtetünk, hogy a dTAF10 fehérjék hiányában is kialakulhat funkcionálisan müködö dTAF4 és dTAF5 tartalmú dTFIID komplex. További kísérleteinkben az egyes dTFIID alegységek fehérjeszintjét vizsgáltuk kontroll és dTAF10 fehérjéket nem tartalmazó Drosophilákban. A kontroll és a dTAF10 hiányos állatokban közel azonos dTAF5 és dTAF1 fehérje szintet detektáltunk, míg a dTBP és a dTAF6 fehérjék szintje a kontrollhoz képest jelentősen lecsökkent a dTaf10 ${ }^{d 25}$ mutáns lárvákban. Eredményeinkből arra következtettünk, hogy a dTAF10 fehérjék nincsenek hatással a dTAF5 fehérje szintjére, 
viszont a jelenlétük szükséges ahhoz, hogy a dTAF5 tartalmú dTFIID kötődni tudjon a gének promóter régióihoz. Ezzel ellentétben a dTAF1, valamint a dTBP tartalmú dTFIID lokalizációja nem függ a dTAF10/dTAF10b fehérjék jelenlététől. Eredményeink rávilágítanak arra, hogy a dTAF10/dTAF10b befolyásolják bizonyos dTFIID szubkomplexek összeszerelődését.

Fenotipus vizsgálatok során azt láttuk, hogy a $d \operatorname{Tafl}^{d 25}$ mutáns állatok körülbelül 50\%-a késői L3 stádiumban elpusztul. Korábbi kísérleteinkben igazoltuk, hogy a dATAC mutánsok L3 lárvális letalitása az ekdizon hiánya miatt következik be, ezért feltételeztük, hogy a dTAF10 fehérjéket nem tartalmazó Drosophilákban is az ekdizon hiánya lehet felelös az L3 végi letalitásért. Ezért a $d T a f 10^{d 25}$ L3 lárvákat ekdizonnal kiegészített standard, illetve normál táptalajon neveltük. Azt láttuk, hogy az ekdizonnal kiegészített táptalajon fenntartott lárvák több mint $80 \%$ elérte a báb stádiumot. Eredményeinkből feltételeztük, hogy az L3 végi letalitás az ekdizon hiánya miatt következik be. Az ekdizon koleszterinből szintetizálódik a gyürümirigy sejtjeiben, majd a hemolimfába szekretálódik, majd a zsírtestben expresszálódó shade által kódolt enzim átalakítja 20-hidroxi-ekdizonná. Az ekdizon hiányos állapotot az is okozhatja, hogy nem áll rendelkezésre elegendö koleszterin, melyet a lárvák a táptalajból vesznek fel. Ezért dTaf10 ${ }^{d 25}$ lárvákat koleszterinnel kiegészített normál táptalajon, valamint standard táptalajon tartottuk fent. Azt láttuk, hogy a koleszterin nem menekítette az L3 végi letális fenotípust. Ezáltal megállapítható, hogy az ekdizon hiánya $d T a f 10^{d 25}$ mutánsoknál nem abból adódik, hogy nem áll rendelkezésre elegendő metabolikus prekurzor az ekdizon szintéziséhez. További kísérleteinkben vizsgáltuk, hogy a dTAF10 hiánya befolyásolja-e a gyürümirigyben végbemenő folyamatokat, melyek fontos szerepet játszanak az ekdizon szintézisében. Ehhez először dTaf10 specifikus RNS interferencia Drosophila vonalak segítségével vizsgáltuk, hogy a dTaf10 mRNS szintjének csökkentése specifikusan a gyürümirigyben milyen fenotípust eredményez. Azt láttuk, hogy a dTaf10 expressziójának csökkentése - a dTaf10 ${ }^{d 25}$ mutánsokhoz hasonlóan - L3 végi-korai báb letalitást eredményez. Az ekdizon azonban menekítette az dTaf10 expresszió csökkenése során kialakuló L3 végi letalitást. Ezáltal feltételeztük, hogy a dTAF10 hiánya befolyásolja a gyürümirigyben végbemenő ekdizon bioszintézist. További kísérleteinkben azt láttuk, hogy nemcsak a dTaf10 de a dTaf5, illetve a dTaf8 gyürümirigybeli expressziójának csökkentése is L3 végi letalitást eredményezett. Emellett az ekdizon menekítette a dTaf5, dTaf8 expresszió csökkentése miatt kialakult L3 végi letális fenotípust. Eredményeink azt sugallják, hogy a dTAF5, 
dTAF8, dTAF10 tartalmú dTFIID komplex fontos szerepet játszik a gyürümirigyben végbemenő ekdizon szintézisben.

Kutatócsoportunk korábban kimutatta, hogy az $d A d a 2 a^{d 189}$ (dATAC) mutánsokban ekdizon szintézisben résztvevő Halloween gének expressziója lecsökken. Továbbá microarray adatok összehasonlításával azt tapasztaltuk, hogy a dTAF10/dTAF10b hiányában kialakuló transzkripciós változások nagymértékben hasonlítanak az dADA2a hiányában bekövetkező transzkripciós változásokhoz. Ezért vizsgáltuk, hogy dTAF10/dTAF10b hiánya befolyásolja-e az ekdizon bioszintézisben szerepet játszó gének expresszióját. A microarry adatok azt mutatták, hogy a dTaf $10^{d 25}$ mutánsokban csökken a gyürümirigyben expresszálódó ekdizon bioszintézisben szerepet játszó úgynevezett Halloween gének (spookier, phantom, disembodied, shadow neverland) mRNS szintje. A periferiális szövetekben expresszálódó shade mRNS szintje viszont nőtt dTAF10/dTAF10b hiány esetén. Eredményeink azt sugallják, hogy a dTAF10/dTAF10b tartalmú komplexek befolyásolják a gyürümirigyben expresszálódó Halloween gének transzkripcióját.

A $\quad d A d a 2 a^{d 189}$ valamint a $d T a f 10^{d 25}$ mutánsok micorarray adatainak összehasonlításánál azt láttuk, hogy az ekdizon bioszintézisben résztvevő gének expressziós mintázata nagymértékben hasonlít a dATAC valamint a dTaf10 $0^{d 25}$ mutánsokban. Eredményeink arra utalnak, hogy az dATAC, valamint a dTaf10 $0^{d 25}$ mutánsokban tapasztalt transzkripciós változások nagyrészt az ekdizon hormon hiánya miatt alakulnak ki, valamint mind az dATAC, mind a dTAF10/dTAF10b tartalmú komplexek együttes müködése nélkülözhetetlen az ekdizon által szabályozott egyedfejlödésben. 


\section{Summary}

As a first step of eukaryotic transcription initiation, TFIID binds to the promoter region of transcribed genes. The TFIID complex consists of TBP, which binds to the TATA box region, and TAF proteins, which bind to the TBP protein. The core TFIID is conserved in eukaryotes and it consists of double copies of TAF4, TAF5, TAF6, TAF9 and TAF12 which together create a two-fold symmetric structure. The additional TAF8-TAF10 heterodimer induces conformational changes by abolishing the two-fold symmetry. TBP and further peripheral TAF proteins bind to the 7 TAF protein containing TFIID core complex (TAF4, TAF5, TAF6, TAF8, TAF9, TAF10, TAF12). TAF proteins are parts of both dTFIID and the dSAGA histone acetyl transferase (HAT) complex, which acetylates histone proteins by transferring acetyl groups from acetyl-coenzymeA. Two GCN5 containing histone acetyltransferase complexes (dATAC and dSAGA) are present in Drosophila. Although dSAGA and dATAC complexes have common subunits in their HAT modul, such as GCN5, SGF29 and ADA3, they regulate different biological processes. dATAC and dSAGA have different substrate specificity: dSAGA acetylates the lysines in the 9th and 14th position of $\mathrm{H} 3$ histone and dATAC acetylates the lysine in the 5th and 8th of $\mathrm{H} 4$ histone.

In Drosophila melanogaster, two TAF10 homologue proteins have been identified, however their functions have been unrevealed yet. In this study we investigated dTAF10 and dTAF10b which show homology with human TAF10. TAF10 is a component of dTFIID and dTAF10b is a subunit of the dSAGA complex. For the functional analysis of dTAF10 and dTAF10b, we generated a mutation which eliminated the production of both Drosophila dTAF10 orthologues. Although the dTAF10b is part of dSAGA complex, the microarray analysis showed that mutations either in dATAC subunit $\left(d A a d a 2 a^{d 189}\right)$ or in dTaf10 genes resulted similar changes in the steady state mRNA levels. This observation suggests that dTAF10/dTAF10b containing complexes and dATAC take part in similar biological pathways. Therefore, we investigated the connection between the dTAF10/dTAF10b containing- and the dATAC-complexes.

First we investigated whether the ablation of dTAF10 and dTAF10b has any effects on the HAT activity of dATAC and dSAGA complexes. Therefore, we examined the global histone acetylation level in $d$ Taf $10^{d 25}$ mutant animals. We found that dSAGA specific H3K14 acetylation level was reduced by the ablation of dTAF10/dTAF10b but the dATAC 
dependent H4K12 and GCN5 specific H4K8 acetylation levels remained comparable to the controls in $d$ Taf $10^{d 25}$ mutants. Furthermore, the level of dSAGA specific H3K9 acetylation did not show any differences between the control and the $d T a f 10^{d 25}$ mutants. These results indicate that the dTAF10b protein is a stable component of dSAGA and the ablation of dTAF10/dTAF10b does not affect the HAT activity of the dATAC complex.

Next we investigated whether the ablation of dTAF10 and dTAF10b has an effects on the binding of dTFIID and dSAGA subunits to Drosophila polytene chromosomes. To test this, we performed immunostaining experiments on polytene chromosomes of $d T a f 10^{d 25}$ mutant larvae and we examined the localization of dTBP, several dTAF proteins and dADA2b. We observed that dADA2b localization was not altered in the absence of dTAF10/dTAF10b as compared to the control, suggesting that the decreased level of dSAGA specific H3K14 acetylation was not due to the functional defect of dADA2b. On the other hand, dTAF10b can play an important role by the HAT activity of dSAGA complex. The localization of dTAF5 was reduced on the polytene chromosomes in

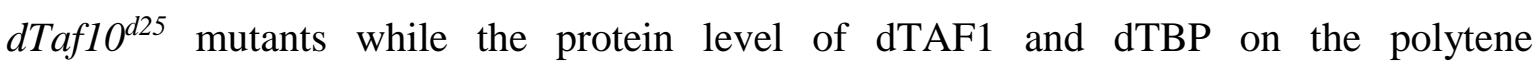
chromosomes was comparable with the control animals. The decreased level of dTAF5, which is a subunit of the core dTFIID, indicates that the ablation of dTAF10 and dTAF10b results the degradation of dTFIID complex. We used co-immunoprecipitation to reveal whether dTAF4-dTAF5 subcomplex was formed in $d T a f 10^{d 25}$. We showed that the dTAF4 and dTAF5 can interact even in absence of dTAF10 and dTAF10b. Next we measured the

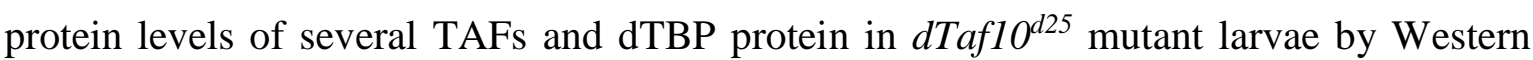
blot. We could not detect alterations in the protein level of dTAF1 and dTAF5 in the absence of dTAF10/dTAF10b compared to the control samples. On the contrary, the

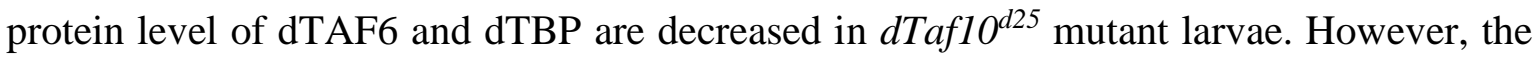
dTAF4-dTAF5 containing dTFIID can be formed in the absence of dTAF10 proteins, the protein levels of dTAF5 was decreased on the polytene chromosomes. These results indicate that the dTAF10/dTAF10b proteins do not affect the dTAF5 protein level but the absence of dTAF10 proteins disturbs the binding of dTAF5 containing complexes on polytene chromosomes. The dTAF1 and the dTBP containing dTFIID are able to bind to chromosomes of $d \operatorname{Tafl}^{d 25}$ mutant animals but the protein levels of dTBP and dTAF6 were decreased in absence of dTAF10 proteins. This indicates that the dTAF10/dTAF10b can influence the formation of several dTFIID subcomplexes. 
We found that the $d \operatorname{Taf} 10^{d 25}$ mutants were unable to form normal pupa and approximately $50 \%$ of animals died at L3 larval stages. Earlier experiment showed that the absence of dADA2a proteins caused similar phenotype. In dATAC mutants the absence of molting hormone ecdysone resulted in animal lethality. We assumed that the dTaf10 $0^{d 25}$ mutants died in L3 larval stage due to the lower level of ecdysone. To test this, we fed $d \operatorname{Taf}_{10} 0^{d 25} \mathrm{~L} 3$ larvae with 20-hidroxyecdysone and we observed that more than $80 \%$ of L3 larvae reached the pupa stage. Ecdysone is synthesized from cholesterol in the ring gland. First we checked whether a failure in cholesterol uptake resulted in defects in pupariation. We fed the L3 larvae with cholesterol containing medium but the cholesterol was unable to rescue the pupariation defects. This result indicated that it was not the lack of molecular precursor that caused the absence of ecdysone. Next, we investigated whether gene expression changes and the morphogenesis delay caused by the lack of dTAF10 were due to the lack of ecdysone hormone. Since ecdysone is synthesized in the prothoracic gland, we eliminated dTaf10 messengers only in the prothoracic gland cells by producing siRNA against dTaf10 with the help of a phantom-GAL4 driver. We found that the decreased level of dTaf10 mRNA in the ring gland caused similar phenotype as we detected in the absence of dTAF10 proteins. Ecdysone feeding restored ability of larvae to form puparium. These results indicated that the gene expression changes and failure in morphogenesis of dTAF10 mutant animals were due to the lack of the molting hormone ecdysone. To further test this, we expressed siRNA constructs against dTaf5 and dTaf8, two subunits of the 7TAF submodule of the dTFIID complex in the prothoracic gland. As we expected, the targeted silencing of $\mathrm{d}$ Taf5 and $\mathrm{d} T a f 8$ resulted in similar loss of molting phenotype, as was detected in dTaf10-silenced animals. dTaf5-, dTaf8-and dTaf10-silenced animals could reach the early pupal stages by ecdysone feeding. Together, these results suggest that dTFIID has an essential regulatory function in early stages of ecdysone hormone biosynthesis in prothoracic cells.

Earlier experiments showed that the mutations in dATAC subunits resulted in decreased expression levels of ecdysone biosynthetic genes. The similar changes between the dADA2a and dTAF10/dTAF10b specific transcriptomes prompted us to check whether dTAF10 proteins are also necessary for the expression of the P450 cytochrome genes. The microarray data showed that the Halloween genes (spookier, phantom, disembodied, shadow neverland), which were expressed in ring gland and involved in ecdysone bioshynthesis, were downregulated in $d T a f 10^{d 25}$ mutant animals. In contrast with this the expression of shade, which is expressed in peripherial tissues such as midgut and larval fat 
body, was increased in absence of dTAF10/dTAF10b. We found similar changes in expression levels of ecdysone biosynthetic genes in dATAC mutants when we compared the microarray data of $d A d a 2 a^{d 189}$ with the microarray results of $d \operatorname{Tafl}^{d 25}$ mutants. This result and the similar phenotypes, which were detected in the absence of both dTAF10 proteins and dADA2a, indicate that the dTAF10/dTAF10b containing complexes and the dATAC complex together regulate the ecdysone-driven morphogenesis through the regulation of the transcription of ecdysone biosynthetic genes. 


\section{Támogatások:}

- A sejtek fehérjeháztartását szabályozó folyamatok vizsgálata újszerü genetikai és proteomikai módszerekkel.

GINOP-2.3.2-15-2016-00032

- Az SZTE Kutatóegyetemi Kiválósági Központ tudásbázisának kiszélesítése és hosszú távú szakmai fenntarthatóságának megalapozása a kiváló tudományos utánpótlás biztosításával.

TÁMOP-4.2.2/B-10/1-2010-0012 